BNL 50679

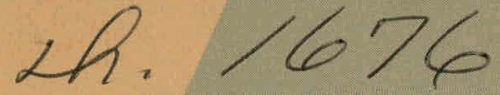
$1_{17-1}^{1,77}$

BROOKHAVEN NATIONAL LABORATTORY REGIONAL ENERGY STUDIES PROGRAM

\title{
STATE LEGISLATURES AND ENERGY POLICY IN THE NORTHEAST: ENERGY FACILITY SITING AND LEGISLATIVE ACTION
}

\section{June 1977}

\section{POLICY ANALYSIS DIVISION}

NATIONAL CENTER FOR ANALYSIS OF ENERGY SYSTEMS

BROOKHAVEN NATIONAL LABORATORY

UPTON, NEW YORK II973

Prepared for the

UNITED STATES ENERGY RESEARCH AND DEVELOPMENT ADMINISTRATION 


\section{DISCLAIMER}

This report was prepared as an account of work sponsored by an agency of the United States Government. Neither the United States Government nor any agency Thereof, nor any of their employees, makes any warranty, express or implied, or assumes any legal liability or responsibility for the accuracy, completeness, or usefulness of any information, apparatus, product, or process disclosed, or represents that its use would not infringe privately owned rights. Reference herein to any specific commercial product, process, or service by trade name, trademark, manufacturer, or otherwise does not necessarily constitute or imply its endorsement, recommendation, or favoring by the United States Government or any agency thereof. The views and opinions of authors expressed herein do not necessarily state or reflect those of the United States Government or any agency thereof. 


\section{DISCLAIMER}

Portions of this document may be illegible in electronic image products. Images are produced from the best available original document. 


\title{
STATE LEGISLATURES AND ENERGY POLICY IN THE NORTHEAST: ENERGY FACILITY SITING AND LEGISLATIVE ACTION
}

\author{
David Morell and Grace Singer \\ Center for Environmental Studies \\ Princeton University, Princeton, N.J. 08540
}

This repon was prepared as an account of work
sponsored by the United States Govemment. Neither the
United States nor the United States Depastment of
Energy, nor any of their employecs, nor any of their
contractors, subcontractor, or their employees, makes
ony warranty, express or implied, or assumes any legal
liability or responsibility for the accuracy, completeness
or usefulness of any information, apparatus, product or
process disclosed, or represents that its use would not
infringe privately owned rights.

June 1977

POLICY ANALYSIS DIVISION

NATIONAL CENTER FOR ANALYSIS OF ENERGY SYSTEMS

BROOKHAVEN NATIONAL LABORATORY

ASSOCIATED UNIVERSITIES, INC.

\begin{abstract}
Work Supported By
THE DIVISION OF TECHNOLOGY OVERVIEW,

ASSISTANT ADMINISTRATOR FOR ENVIRONMENT AND SAFETY, UNITED STATES ENERGY RESEARCH AND DEVELOPMENT ADMINISTRATION UNDER CONTRACT NO. EY-76-C-02-0016.
\end{abstract}


NOT I C E

This report was prepared as an account of work sponsored by the United States Government. Neither the United States nor the United States Energy Research and Development Administration, $n n r$ any of their emplinyrrs, I!ur any of thcir contuaciurs, sulucontractors, or their employees, makes any warranty, express or implied, or assumes any legal liability or responsibility for the accuracy, completeness or usefulness of any information, apparatus, product or process disclosed, or represents that its use would not infringe privately owned rights.

Printed in the United States of America

Available from

National Technical Information Service

U.S. Department of Commerce

5285 Port Royal Road

Springfield, VA 22161

Price: Printed Copy $\$ 9.00 ;$ Microfiche $\$ 3.00$

July 1977

775 copies 
STATE LEGISLATURES AND ENERGY POLICY IN THE NORTHEAST:

ENERGY FACILITY SITING. AND LEGISLATIVE ACTION

Table of Contents

\section{Chapter}

I. Introduction and Approach . . . . . . . . . . . . . 1

State Legislatures and Energy Policy ......... 1

The Energy Challenge .. . ... . . . . . . 3

Approach to The Research . . . . . . . . . . . 6

II. New Jersey: Inertia in the Energy Policy Arena . . . . . . . . 9

Structure for Energy Policy Formulation . . . . . . . 11

Energy-Related Legislation in New Jersey . . . . . . 20

Proposed Legislation on Energy Policy . . . . . . . . 40

Legislative Hearings Related to Energy .........63

Conclusions . . . . . . . . . . . . . . 66

III. Maryland: Initiatives in Power Plant Siting . . . . . . . . 79

Legislative Structure . . . . . . . . . . 79

Energy Facility Siting Legislation: The Power

Plant Siting Act of 1971 .......... 80

The Coastal Facilities Review Act of 1975 . . . . . 93

Other Legislation Related to Energy Facility Siting • 98

Other Energy-Related Legislation . . . . . . 102

Conclusions . . . . . . . . . . . . 104

IV. New York: Focus on Power Plant Siting . . . . . . . . . . 109

Legislative Structure . . . . . . . . . . 109

Legislative Activity on Energy Issues . . . . . . . 111

Energy Facility Sittng Legislation: The Power Plant

Siting Act . . . . . . . . . . . . . 118

Wetlands, Flood Plains, and Coastal Protection Laws - 127

Legislation Specific to Nuclear Facilities . . . . . 128

Conclusions . . . . . . . . . . . . 130

V. Pennsylvania: Policy Limitations in an Energy-Producing

State ........................ 134

Legislative Structure for Energy Policy . . . . . 134

Overa11 Legislative Activity . . . . . . . . . 135

Energy Facility Siting Activities . . . . . . . 135

Strip Mining Legislation .............. . 144

Recent Legislative Actions on Energy . . . . . . 145

Conclusions . . . . . . . . . . . . . 146 
Legislative Structure for Energy Policy . . . . . . . 150

The Coastal Zone Act and Energy Facility Siting . . . . 152

Other Land Use Laws Related to Energy Facility

Siting . . . . . . . . . . . . . . 165

Nuclear Energy Reassessment . . . . . . . . . . 166

Controversy Over Taxes on Energy Facilities . • . . . 167

Other Energy Legislation . . . . . . . . . . . . 171

Conclusions . . . . . . . . . . . . . . 172

VII. The New England Region: Reliance on Petroleum and Rejection

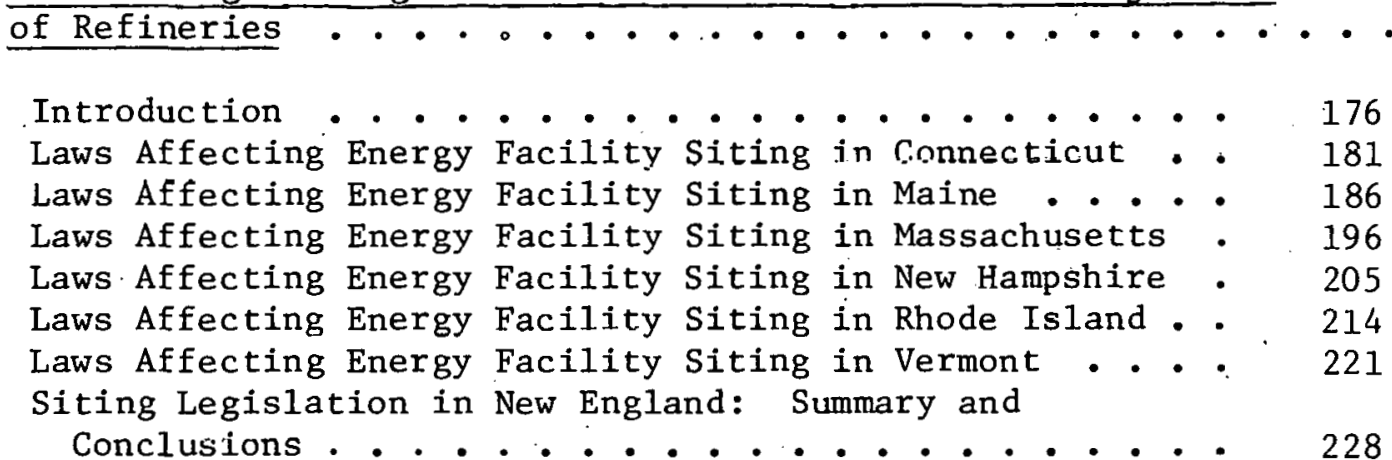

VIII. Summary, Conclusions and Recommendations . . . . . . . . .

Overall Energy Policy............. 239

Decisions on Energy Facility Siting . . . . . . . . 246

Formulation of Federal and State Policy and Standards . . 252

Establishment of and Roles for State Energy offices . . . 253

Structure and Staffing for Energy Policy in State

Leg1slatures . . . . . . . . . . . . . 254

Recommendations . . . . . . . ....... . 255

Reglonal Coherence and Efffective Leadership . . . . . . 259

Tables

I New England Refineries Planned but iNot Constructed Due to Public Opposition . . . . . . . . . . 179

Figures

1 New Tersey Coastal Zone . . . . . . . . . 27

2 Delaware Coastal 7onne . . . . . . . . . . 156

3 Existing Industrial Ownership ......... 157 
State Legislatures and Energy Policy

At the federal level, a vast array of bureaucratic and legislative institutions are presently immersed in various explorations of energy policy and its national ramifications -- from the Energy Research and Development Administration to the Congress' Office of Technology Assessment, from the Office of Coastal Zone Management in the Department of Commerce to the Environmental Protection Agency. Similarly, almost every one of the 50 states has an Energy Office, a Public Utilities Commission, and other executive branch agencies involved in making or carrying out energy policy for the state. Extensive studies have been made of many of these institutional actors, in order to comprehend more fully their roles and functions, their strengths and weaknesses.

One element of the institutional/political equation, however, of ten is missed in studies of energy policy: the state legislature. This institution may well be vitally important to formulation of broad policies, and certainly is critical to successful implementation of certain aspects of those policies -especially when new enabling legislation, new tax incentives, or new regulatory powers are required. The state legislature frequently is perceived by academic researchers and executive branch officials as an obstacle to be overcome, the point of recalcitrant resistance. Although this may be correct in some instances, of ten a great deal of positive intiative emanates from the legislatures. These actions represent an important input to formulation of energy policies, from supply increases through facility siting to demand reduction through conservation measures. These actions must be sensitive to popular concerns and committments. 
The research on which this report is based has been designed to identify and assess several features of state legislatures in the Northeast region, from the particular focus of energy policy. Eleven states are included in this region, stretching from Maine to Maryland。 Starting from documentation and analysis of legislative organization for energy (committees, staff capabilities, information base, and so on), we move to an assessment of the history of selected items of energy-related legislation which have been passed by state legislatures, or failed in passage. Significant recent allivlty in the state legislatures of the Northeast has been examined from a comparative focus, in order to gain a regional perspective on the performance of these key Institutions. The analysis has emphasized leglslative action with respect to energy facility siting, because of the clarity of difficult public policy choices in that area. Thus the study includes description and analysis of the various laws affecting siting which have been enacted by legislatures in each of the Northeast states.

This study has been restricted primarily to analysis of elected legislatures, including their role and impact in coping with the challcnge of energy policy formulatinn. The many actiuns of State Energy offices, Public Utility Commissions, Energy Facility Siting Agencies and other elements of the executive branch have been studied only to the degree necessary to evaluate the impact of particular items of legislation. In other words, this is not a comprehensive study of the states and energy policy, but only of the performance of the elected institutions in that process. 
Energy has taken its place in the American vocabulary as one of the most frequent topics of discussion in government, industry, science, the media and among concerned consumers. This turn of events, a result of longterm trends in energy consumption in the U.S., was made apparent with stunning impact in October, 1973, with the advent of the OPEC embargo of oil shipments to the United States. The embargo struck at the heart of the American standard of living: unrestricted automobile use, thriving industry and comfortably heated homes.

This dramatic event, lasting through the winter of 1973-74, precipitated intense discussion in state legislatures across the country... and some action. However, pressures dictating rapid response to the energy. challenge were alleviated with arrival of warmer weather and lifting of the embargo, albeit at greatly increased costs for fuel and electricity. Nevertheless, other related complex issues soon surfaced pertaining to. American energy self-sufficiency: among others, drilling for oil and gas in the Outer Continental Shelf of the U.S. East Coast, California, and Alaska; increasing reliance on nuclear energy; and the environmental implications of expanded use of U.S. coal resources through strip mining, gasification, or relaxed air quality standards. In the 1970's, Americans -- with 6 percent of the world's population -- consumed approximately 33 percent of total world output of energy. If this imbalance was to continue, further domestic energy supplies appeared essential.

Because energy traditionally has been relatively cheap and plentiful in America, the long-term causes of the crisis regarding consumption and production had not become a prominent public issue. One of the widespread explanations of the crisis during the winter of 1973-74 suggested that it 
was a result of a conspiracy by the major oil companies to eliminate competition and increase profits. This theory received much attention and was discussed in almost every state legislature. One of the issues giving impetus to the conspiracy theory was the fact that in January and February, 1974, independent and franchised gasoline dealers were going out of business at the rate of about 200 closings per week because they were unable to obtain gasoline. In most cases, the independents obtained their supply of gasoline from the major oil corporations. However, many of these stations were reopened for business as soon as the former franchise operator had vacated the premises. ${ }^{1}$ Due to lack of definitive data on production, distribution and pricing -data known only to the oil companies -- these conspiracy accusations could neither be substantiated nor refuted.

These events generated a lingering skepticism as to the true nature of the energy crisis, affecting attitudes and actions in state legislatures. This factor also may have played a part in relaxation of efforts to devise needed new energy policies after initial high activity following the embargo. Many legislators, reflecting their own constituents' beliefs, felt that perhaps the energy "crisis" had been contrived, and that there was no need to be overly concerned.

Nowhere was the energy crunch felt with greater impact than in the heavily populated, industrialized Northeastern section of the United States, an area uniquely deficient in energy resources except for Pennsylvania's abundant coal supplies. To meet its energy requirements, the Northeast imports some 90 percent of its fuel resources from outside the region. In 1972, fossil fuels consumed in the region came from the following sources:

\section{Source}

Ind igenous Other Regions of the U.S. Foreign Imports

\section{Percent}

$12.8 \%$

$47.5 \%$

$39.7 \%$ 
Most of the indigenous component was Pennsylvania coal, consumed within that state.. The foreign import proportion has continued to increase since 1972, and following the 1973-74 embargo the Northeastern states have experienced accelerated high energy costs, creating financial strains on industry, commerce, public institutions, and the consumer segments of society.

In this setting, activity within the state legislatures was initially intense: establishing fuel allocation agencies, granting emergency powers to Governors, creating special commissions to investigate the problem, and so on. This intense activity slackened markedly after 1974 , however, with most legislatures returning to a "business as usual" stance.

Increasingly, legislators have begun to perceive the long-term nature of the energy problem. At the same time that pressures are mounting to increase domestic energy supplies, elected.representatives have been under pressure to take various initiatives to protect their states' ecologicallyfragile coastal resources from possible deleterious impacts of offshore energy activity, including impacts on community infrastructure. Siting contradictions are particularly evident in coastal regions, where energy facilities' water needs compete with recreation, tourism and commercial fishing.

This issue takes on a special importance in the Northeast, where 10 of the 11 states (Vermont is the only exception) have coastal geographies. For example, New Jersey has had several precedent-setting energy proposals placed at 1ts doorstep at the same time: drilling for oil and gas in the Baltimore Canyon area of the Outer Continental Shelf; construction of two floating nuclear power plants 2.8 miles offshore from Little Egg Inlet (12 miles northeast of Atlantic City); ${ }^{3}$ and selection of Ocean County as the hypothetical site for a large (20 reactor) nuclear energy center. ${ }^{4}$ 
Complex, highly technical energy proposals constitute a whole new dimension in the state legislatures, and as such have met with varied responses.

In recognition of the regional nature of energy and other economic and social problems, a coalition of Northeastern governors (CONEG) was created in the fall of 1976 to revive the area's economy. The nucleus of this group consisted of seven Democratic governors from Connecticut, Massachusetts, New Jersey, New York, Pennsylvania, Rhode Island and Vermont. The Republican governor of New Hampshire and Independent governor of Maine were invited to the November conference of CUNEG, but aree not members. CUNEG Intends ro form a regional Energy Development Corporation (EDC) to promote conservation; accelerate the development of eastern coal to lessen the Northeast's dependence on imported oil; plan and construct new energy facilities; and underwrite research into new sources of energy. Funding would come from the member states, and CONEG is seeking federal guarantees for the bonds the agency would issue to carry out its work. It is possibie that EDC's efforts, if successful, would result in an economic boost for the Northeast similar to that given the Southeast in the $1930^{\prime}$ 's through the Tennessee Valley Authority.

\section{Approach to the Research}

This study covers three main aspects of energy policy formulation and action by state legislatures: (1) legislative structure; (2) enactment of energy facility siting laws; and (3) passage (or defeat) of significant energy legislation of a more general nature. Emphasis has been placed on energy facility siting statutes and approaches for two reasons. First, energy facilities have a great impact on land use, environmental quality and economic growth. Second, siting of these facilities raises inherent 
conflicts in the attempt to achieve balance between potentially contradictory objectives. Elected legislatures are uniquely suited -- at least in theory -to effect such balance; "representative legislatures provide the surest way to order the deep divisions among men into viable social choices". 5

The states of New Jersey and Maryland have been examined in considerable depth for this study. New Jersey provides an example of legislative paralysis regarding energy policy, Maryland of legislative innovation, at least regarding energy facility siting. Legislative activity in the states of New York, Pennsylvania and Delaware has been assessed in somewhat less detail. Resource constraints limited the report on the six New England states (Connecticut, Maine, Massachusetts, New Hampshire, Rhode Island and Vermont) to description and some analysis of laws affecting energy facility siting. The subjects of legislative structure and of other energy laws in New England will have to be pursued through further study, to obtain a more complete understanding of legislative activity regarding energy throughout the Northeast region.

Most research data were obtained by analysis of legislation and by telephone interviews. In the case of Maryland, a full day was spent with officials in Annapolis to provide an in-depth report on that state's unique energy facility siting law; and in New Jersey, extensive interviews were used. Most telephone interviews were with members of state legislative research staffs, and with officials of relevant state agencies. Resource data were also gained by extensive contacts with national research organizations and federal agencies, particularly on energy facility siting. Since no single publication provided information on complete legislative activity through the 1976 sessions in the areas studied, individual state contacts 
became the principal sources of recent information, with the exception of the New England states which have a unique institutional research mechanism: the New England Regional Commission. This group's Energy Research and Policy Formulation Program compiles comprehensive regional data on laws affecting energy facility siting, although very recent actions were also checked directly with the individual New England states.

\section{Notes to Chapter I}

1. Council of State Governments, State Responses to the Energy Crisis (Lexington, Ky.: " Council of State Governments, March 1975), p. 5.

2. J. Lee, Energy Supply and Demand in the Northeast United States (Upton, NY: Brookhaven National Laboratory, BNL 20427, September 1975).

3. United States Congress, Office of Technology Assessment, Coastal Effects of Offshore Energy Systems, (Washington, DC: US Government Printing Office, November 1976).

4. Peter Meier and David More11, Issues in Clustered Nuclear Siting (Upton, N.Y.: Brookhaven National Laboratory, BNL 50561, September 1976).

5. Edwin T. Haefele, Representative Government and Environmental Management (Baltimore: Johns Hopkins University Press, 1973), p. v. 
NEW JERSEY:

INERTIA IN THE ENERGY POLICY ARENA

The New Jersey state legislature's inertia with respect to energy policy illustrates what happens when a political system becomes mesmerized by a single public policy issue, to the detriment of progress regarding other important issues, such as energy. Ever since Governor Brendan T. Byrne's term of office began in January 1974, New Jersey's political process has been preoccupied with intense intra-party conflict over tax policy and related fiscal issues. Although the same political party -- the Democrats -controls both the executive branch and the legislature, resolution of the fiscal dilemma proved very difficult.

The battle centered on the search for a broad-based (income) tax to finance state services, particularly education. The State Supreme Court had ordered public education to be financed on what the New Jersey constitution calls a "thorough and efficient" basis, rather than through local property taxes alone. These, the Court held, create too-great disparities in school financing between individual municipalities or school districts. The legislature, especially the State Sanate, failed over almost the entire term to pass a state income tax measure, despite several attempts. Only after the State Supreme Court ordered schools closed pending agreement on equitable financing did the legislature finally pass an income tax bill, signed into law by the Governor on July 8, 1976. While the taxation conflict was underway, New Jersey's state legislature devisea little significant energy policy, nor did it enact any major items of energy-related legislation. 
Nevertheless, energy remains a vital public policy issue in New Jersey, the nation's most densely populated state. New Jersey has a large energyintensive industrial establishment, dependent on natural gas (now in increasingly short supply) ${ }^{1}$ and on imported fuel oil (with its implications for today's high prices and tomorrow's potential embargo). The state is adjacent to the areas of expected drilling for oil and gas in the Baltimore Canyon Trough area of the Outer Continental Shelf (OCS). ${ }^{*}$ It has been proposed as the location for a possible Deepwater Port to accommodate supertankers (Very Large Crude Carriers). Either or both of these developments would stimulate pressure for construction -- and therefore for siting -- of numerous onshore energy facilities. Already, New Jersey is home for a massive petrochemical complex, including 34 percent of the entire petroleum refining capacity from Maine through Florida. ${ }^{2}$ Moreover, the state's electric utilities are advancing their plans for development of further nuclear energy facilities, including the innovative concept for a floating nuclear power plant some 2.8 miles off the state's coastline near Atlantic City.

Many of the bills pending in the New Jersey legislature in late 1976 proposed policies which were recommended originally by a special Governor's Task Force on Energy (coordinated by the State Energy Office) in its May, 1974 report. This group made several recommendations, including:

- state energy planning;

- escablishment of a Department of Energy;

- cumprehensive energy conservation measures; and

- study of electricity rate structures.

\footnotetext{
${ }^{*}$ Governor Byrne in h1s January 11, 1977, State of the State speech to the legislature outlined what he hoped the slate would derive from OCS oil and gas drilling: jobs in onshore support facilities, but not in any new oil refineries since "New Jersey has enough refineries"; more natural gas and oil available for the state; oil and gas to come ashore in underground pipelines to avoid spill accidents; all while continuing "to have the finest beaches in the United States". 3
} 
To date, none of the Task Force's recommendations have been enacted, although they have served as the background to what little debate has ensued.

New Jersey's legislature, and its executive branch as well, cannot

forever avoid a direct focus on energy policy, including an overall strategy, siting questions, and various proposals for energy conservation. The follewing chronicle of the state's limited legislative record on energy issues to date attests in large measure, however, to the preoccupation of the legislature and Governor with the fiscal quagmire, the overall lack of strong leadership, the absence of any clear legislative mandate for extensive energy planning, and the ambiguous constituency for a new approach to energy policy in the state.

\section{Structure for Energy Policy Formulation}

\section{Legislative Committees}

Both houses of the New Jersey legislature have energy committees. The Senate's five-member Energy and Environment Committee (formerly the Energy, Agriculture and Environment Committee) is chaired by Senator John F. Russo, an attorney (Democrat, Ocean County).4 In 1976, the Assembly formed a fivemember Energy and Natural Resources Committee, chaired by Assemblyman John H. Froude (Democrat, Middlesex County), an Assistant Professor of Politica1 Science at Kean College. 5 Previously, energy legislation in the Assembly had been placed in various other committees, including the state Government and Federal and Interstate Relations Committee, the Transportation and Communications Committee, and the Agriculture and Environment Committee.

Despite this new committee structure formalizing energy as a recognized topic in each house, the presiding officer of either body may place energy legislation in other committees. This occurred in 1976, for example, when 
important new energy facility siting legislation was placed in the Senate's

Labor, Inđustry and Professions Committee on which its prime sponsor (Senator Frank Dodd, Democrat, Essex County) is a member. In particular, both the Assembly and the Senate have established committees on Transportation and Communications, the jurisdiction of which includes the Department of Public Utilities and the responsibilities of which include electric and natural gas matters of concern to the state.

\section{Energy Crisis Study Commission}

In addition to these legislative committees, the New Jersey legislature created an Energy Crisis Study Commission in June 1973, prior to the October 1973 fuel shortage crisis. ${ }^{6}$ 'Ihis Commission was an outgrowth of the Senate's Ad Hoc Committee on Energy and Environment, established by order of thenSenate President Alfred Beadleston (Republican, Monmouth County) in January 1973 in response to several important energy-related issues then current. These included Senator Beadleston's perception of the long-term nature of the problem of insufficiency of electric genération evidenced by the blackouts and brown-outs of previous years; proposals for deepwater ports; and plans by the utility companies for major expansion of nuclear power, including the floating nuclear power plant and the proposed facility at Newbold Island on the Delaware River, " only seven miles from Trenton.

This 16-member Commission consists of four members of the Senate (appointed by the President of the senate) and four members of the General Assembly (appointed by the Speaker of the Assemb1y). No more than two Senators or Assemblymen may be members of the same political party. Each legislator on the Energy Commission serves for the duration of the term for

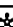

This site was later rejected in the feuleral licensing process; in Jainuary 1977, the state announced plans to acquire the one square mile island to be develope ${ }^{\text {as }}$ a state park and marina. 
which he or she was elected to the legislature. In accordance with amendments to the law in 1974, the Governor appoints eight additional members of the Commission, who serve at his pleasure. ${ }^{7}$ As of September 1976, membership on the Energy Crisis Study Commission was as follows:

\section{$\underline{\text { Senate }}$}

Senator Bernard J. Dwyer (Democrat, Middlesex County) Chairman (also Chairman of the Joint Appropriations Committee which deliberated for four months -- from February to May 1976 -- on the difficult problem of the state budget)

Senator Alene S. Ammond (Democrat, Camden County)

Senator Wayne Dumont, Jr. (Republican, Sussex, Warren, Passaic Counties)

Senator Barry T. Parker (Republican, parts of Burlington, Ocean, Monmouth, and Mercer Counties)

Assembly

Assemblyman John H. Froude (Democrat, Middlesex County)

Assemblyman Thomas H. Kean (Republican parts of Essex,

Morris and Passaic County)

(plus two Assembly vacancies)

Appointments by the Governor

Joseph A. Hoffman, Commissioner of Labor and Industry

William F. Hyland, State Attorney General

G. Edward Koenig, businessman, Bordentown

Richard C. Leone, State Treasurer

Eleanore Pettersen, Architect, Saddle River

William Wright, Attorney, Plainfield

(plus two executive appointment vacancies) ${ }^{8}$

Duties of the Commission are defined in the legislation which estab-

lished it:

(1) To study the energy crisis in New Jersey.

(2) To ascertain the increased demands for energy which must be met.

(3) To evaluate methods, types, locations and methods of acquisition of sites for facilities to meet increased demands for energy and replacement of obsolete facilities.

(4) To investigate energy rate structures with an aim of changes therein; to study methods to conserve energy, reduce waste and encourage the development and use of more efficient energy use and to minimize increases in rates to small residential users.

\footnotetext{
*Hoffman and Lconc have eince resigned from state gnvernment.
} 
(5) To make economic and environmental impact studies and analysis in connection with the foregoing. 9

In 1974 , the legislature appropriated $\$ 75,000$ to support.the activities of the Energy Crisis Study Commission, including preparation of an annual report to the Governor. ${ }^{10}$ No reports or written proposals have emerged from the Commission since its inception in late 1973, however, although its staff has gathered material for such reports. The Commission has met neither regularly nor frequently, and as of mid-1976 not at all during that year. ${ }^{11}$

Research resources appear sufficient to carry forth the Commissinn's work, although a good statewide energy data base certainly is not available. ${ }^{12}$ The data base is hampered by various factors, including the seemingly changeable narure of the energy problem and the fact that some key infurmation held by private corporations has not been made available to state energy policy makers. For example, the State Energy office (SEO) has been unahle to obtain basic information such as the proportion of oil products refined in New Jersey which actually remain in the state for subsequent consumption. In an effort to protect individual company trade secrets, the SEO directed its information request to the New Jersey Petroleum Council, the industry's eràde group, but without success. ${ }^{13}$ Ohvinusly. a grsnt daal of information has been made available to the state by private energy and energy-related corporations. Specialists at the legislature, in particular, point to:

"... the cooperative relationships which have consistently been maintained botwcen privale businesses in New Jersey and legislative staff (particularly, the staff to the New Jersey Energy Crisis Study Commission)..."14

In addlition to the data base problem, the absence of an overall energy mechanism, policy or strategy for New Jersey has created a vacuum which has resulted in lack of research direction. However, a large collection 
of energy documents has been accumulated by the Commission's staff and is available for reference use.

Part of the reason for the Commission's lack of productivity may be attributed to the nature of joint commissions in general (consisting in this case of legislative and executive branch members and members of the general public). Perhaps more important, any action on energy in New Jersey -- including by this high-level Commission -- has been constrained by differences of opinion between the Governor and several members of the legislature on overall energy policy, including Outer Continental Shelf (OCS) energy development, and on the preferred location for the State Energy Office. For example, Senators Dodd and Joseph McGahn (Democrat, Atlantic County) have favored OCS development, in contrast to Governor Byrne who has advocated a more cautious approach regarding offshore activities. Senators Dodd and McGahn consistently have expressed concern over the potential onshore impacts of OCS activities, concern manifested in their sponsorship of a comprehensive State Energy Facility Agency Act (discussed later in this chapter). As one source described these two different perspectives:

"The difference between the position taken by Senators Dodd and McGahn, on the one hand, and Governor Byrne, on the other, is that the legislators believe there are significant benefits to be gained from OCS activities off the New Jersey shore, not only in terms of energy and the economy, but with respect to the environment as well, and that the long 'lead times' between energy exploitation on the Outer Continental Shelf will provide sufficient opportunity to properly plan for all induced onshore developments deriving from those OCS activities. Governor Byrne, however, appears to consider the onshore induced effects of OCS activities to be so significant and so adverse that every effort to delay, or even prevent, those OCS activities has top administration prior1ty." 15

As discussed in more detail below, the State Energy Office has had a difficult bureaucratic career. Lacking a clear legislative mandate, it 
has existed under executive order with a skeleton staff and limited budget. Some of those involved have opted for placing. the SEO in. the Department of Labor and Industry, while others(primarily Governor Byrne) have wanted it under the jurisdiction of the Public Utilities Commission. (PUC).* Some legislators (and others) felt that neither agency was an appropriate forum for the Energy Office, because of the possibility in either case of .jurisdictional conflicts of interest. They argued that the SEO should be placed under the jurisdiction of the Department of Law and Public Safety (AttorneyGeneral) as a more neutral site. When the Governor through Executive Urder in October 1974 placed the State Energy Office under the jurisdiction of the PUC, ${ }^{16}$ there was displeasure in the legislature. One serious consequence of this conflict was the lapse of the SEO's statutory basis on June 30,1975 , rendering it helpless to conduct comprehensive energy programs, or even to be very effective in basic data gathering.

Further explanation of the Energy Commission's 1ack of activity and impact is suggested by relevant historical patterns. Under strong Governors, New Jersey's legislature has been responsive to the policy-making initiatives of the executive branch.' In the 1974-76 period, however, the lack of strong executive leadership and the Democrats' intra-party conflicts have allowed the legislature to proceed on its own, without clear direction; the Energy Commission has followed the same path. Consideration has been given to removing the word "Crisis" from the Commission's title to reflect the more permanent nature of the state's energy problems, but even this rather minor action has not been taken.

\footnotetext{
*Borne is a former PUC Chairman.

There was some feeling that the oil interests did not want to fall under the purview of a traditional state regulatory agency, like the PUC, and that these views carried weight with a number of legislators.
} 
A few significant reports were submitted to the Commission in its early months, notably from its Sub-Committee on Urgent Energy Problems chaired by then-Senator William E. Schluter (Republican, parts of Mercer, Hunterdon, Morris, and Middlesex Counties). A report from this group on October 10, 1973, recommended strong energy conservation measures and expressed concern about deficiencies in the state's fuel supply data. The following conclusions were drawn:

"While the lack of some of this information is attributable to genuine uncertainties...other data have simply not been made available by some of the major oil companies serving this state. The unwillingness on the part of some of these companies to openly participate in the public hearings has been a decided handicap to the sub-committee. (It should be noted that the sub-committee is grateful for the cooperation it did receive from a few oil companies)....

Even though our state is a net exporter of petroleum products, this sub-committee has received no assurance from oil companies with refinery operations in New Jersey that this state will receive its equitable share of fuel....

The sub-committee is in complete agreement that relaxation of air standards is not necessary at this time. These hard-won standards were established to contribute to the maintenance of human health and environmental quality. The air quality in New Jersey has definitely improved, especially in the urban centers, in recent years. We do not know -- nor do the oil companies know -- the societal and economic costs which would be incurred by permitting more sulfur to be spewed into our air. It is unthinkable to the sub-committee that our first response to a potential fuel shortage should be to retrench on air quality and health standards, particularly in the absence of absolute, incontrovertible proof of a dire emergency. The energy situation must be faced head-on as an indication of our wasteful use of available resources rather than diverted to a controversy over the amount of dirty air we should create in order to run our snowmobiles and electric golf carts, over-heat and over-cool our homes and buildings, and light up our movie marques and Christmas displays."Il

Senator Schluter also had been Chairman of the Senate's Ad Hoc Committee on Energy and the Environment. The April 5, 1973, recommendations of this committee are summarized later in this chapter; very few of its recommendations have been implemented, however. According to Schluter, during the period of the energy crisis, lobbyists for oil, nuclear and utility interests closely monitored the activities of the Ad Hoc Committee and, in their 
lobbying efforts, may have persuaded some legislators to their point of view. ${ }^{18}$

When the now-defunct Newbold Island nuclear facility was still a serious, active proposal, Schluter and other legislators took a helicopter tour of the site, along with other energy facilities (including the nuclear power plant then operating at Oyster Creek in Ocean County, and the nuclear facility then under construction in Salem County). The Senators heard witnesses on various aspects of energy and the environment at public hearings held by the Ad Hoc Committee in early 1973. Two important concerns emerged: (1) adequacy of procedures for disposal of nuclear wastes; and (2) availability of Delaware River water for power plant cooling. Schluter, other members of the committee, and environmentalists were concerned that this latter need would be used as further justification for building the Tocks Island Dam. ${ }^{19}$ Cabinet Energy Committee

Established by the Governor in 1974 rather than by legislative action, New Jersey's Cabinet Energy Committee (CEC) is important for the high-level policy potential and coordination its structure implies. The Administrator of the State Energy Office is Executive Director of the CEC, whose other members consist of the Governor (Chairman), the PUC Chairman (Vire Chairman), the other PUC Commissioners, the Commissioners of the Departments of Labor and Industry, Environmental Protection, Community Affairs, Transportation, and Agriculture, the Attorney Genera1, the State Treasurer and the Counse1 to the Governor. The purpose of the CEC is to advise the Governor on development and implementation of energy policy for the state. The CEC meets monthly. One important item of discussion in 1976 was Outer Continental

Shelf policy: how should the state respond to federal proposals to drill for oil and gas off the coast of New .Tersey? The Governor urged the federal Interior Department to delay leasing of tracts scheduled for August 1976, 
until proposed federal legislation was in place to protect states against adverse imfacts, and to give them a larger role in the overall prngram. 20 While the CEC has been and remains a good mechanism for high-level policy formulation and coordination of state plans and concepts, it is not really effective in translating policy into action, primarily because all of its members are extremely busy officials with other heavy state responsibilities. The Committee has no ful1-time staff of its own. Its efforts could be augmented by an effective State Energy Office with comprehensive authority, were such an institution to exist in the state; but the legislature (and the Governor) both remain unwilling to take this step. Energy Institutions in Summary

In summary, lack of leadership and an absence of overall energy policy, preoccupation with pressing financial issues, and political divisiveness have ali constituted major constraints to enactment of energy legislation in New Jersey. If energy does become a priority issue in New Jersey's legislature, sufficient staff and data base are or can readily be made available by legislative mandate. According to those involved in legislative research, sufficient staff and data base already are available to fill legislative requirements. Currently, there are 5 full-time staff members experienced in energy matters, and a total of 18 could be made available under an intensive priority program. This latter figure is an improbable requirement and might strain other research work, but represents a theoretical possibility. 21 


\section{Specific Energy Legislation Still in Effect}

As of September 1976, only two statutes specifically related to energy policy and planning and enacted since the energy crisis remain in effect in New Jersey: the 1973 law described above which created the relativelyinactive Energy Crisis Study Commission; ${ }^{22}$ and the bill passed in June 1976 to allow motorists to turn right at red lights (required as a pre-requisite to federal financial assistance under the Energy Policy and Conservation Act of 1975$)^{*}$. 23 Even the legislation authorizing the State Energy Office (SEO) had expired, and proposals to extend or amend this statute have failed to pass. Emergency Energy Legislation Since Expired: The State Energy office

The nature of the state's response to the imminent and evident energy crisis of the winter of 1973-74 -- and to the rapid decline in legislative interest thereafter -- is evident from the passage in February 1974 and subsequent expiration in June 1975 of: "An Act concerning energy and fuels providing for control of the distribution and sale of energy and fuels during emergencies." 24 This law gave the Governor three new powers with respert to energy: (1) authority to proclaim existence of an energy emergency; (2) authority to establi.sh a State Energy Office; and (3) authority to appolnt an Administrator and Executive Director of this Energy office to carry out the provisions of the law. The law gave many specific powers to the Governor and SEO regarding use and distribution of fuel and collection of energy data.

A State Energy Office still exists in New Jersey, functioning under the jurisdiction of the Public Utilities Commission; however, it has had An oil spill bill was signed into law in January 1977; see pp.54-56. 
no statutory basis since the act expired in mid-1975. This lack of legislative mandate has relegated the SEO to a minor role in state energy policy, restricting it primarily to data collection and sponsorship of limited conservation programs. The office certainly bears no resemblance to the. comprehensive energy agencies established in many other states, including California, Connecticut, and, most recently, New York. As mentioned previously (regarding communication with the New Jersey Petroleum Council), even the SEO's basic function of data collection has been frustrated in certain areas since voluntary requests do not carry the weight of legislative mandate.

The transfer of the SEO to the PUC, together with the SEO's loss of stature, resulted in a dispersal of energy policy personnel throughout state government and a departure of some from government service entirely. At the height of the oil embargo during the winter of 1973-74, the SEO had approximately 40 employees; by 1975, it was down to 15 to 20 employees, and by September 1976 it had a staff of 7 who utilized clerical support of the PUC staff. 25

Recent measures coordinated by the SEO include the "right-turn-on-red" traffic bill, drafted by the SEO, and a van pool program for industry. A peak load pricing experiment begun in mid-1976 at Jersey Central Power and Light Co. is being coordinated by the SEO, whose Executive Director is the program's project leader. This experiment will receive $\$ 55,000$ in state funds and services, $\$ 550,000$ from the federal government, and $\$ 600 ; 000$ contributed by the utility company. 26

As of September 1976, a good relationship -- on a personal basis -appeared to exist between the legislature and the SEO. Upon request, SEO administrators attend legislative committee meetings to provide data and *For example, the New Jersey SEO has an annual budget in 1976 of only $\$ 165,000$, compared to. $\$ 850,000$ proposed for a similar agency in New York (see p. 113). 
act in an advisory capacity. For example, SEO Administrator Burt Ross testified before a public hearing of the Senate Committee on Energy and Environment in March, 1976. However, because the Energy Office no longer has any clearly defined legal powers, its scope for initiative is quite limited. Since expiration of the enabling statute, the office has had to operate under Executive Order. The Governor appoints its administrators (as well as members of the Public Utility Commission), who report to him. Legislators are no longer advised formally as to the activities of the Energy office, and this organizational structure renders the connection between the SEO and the legislature generally indirect.

Draft legislation stimulated by the Governor wnuld merge four entitics into a new Cabinet department. Under this proposal, the Departments of Banking, Insurance, and Public Utilities (including the Energy Office) would be merged into a single "Department of Regulated Commerce." The legislature may choose one of the following alternatives:

1. Renew expired legislation, giving defined legal powers Lo Llie State Energy Uftice.

2. Legislate creation of the nepartment of Regulated Commerce, to include the Energy office. (There io opposition to this, particularly from the departments to be merged).

3. By doing nothing, leave the situation as it is.

\section{Legislation Affecting Energy Facility Siting}

While New Jersey has a relatively comprehensive set of environmental control laws, none deal directly with power plant siting. In 1970, the New Jersey Department of F.nvironmental Protcrtion (DES) was etulublluhed by merging virtually all of the state's functions relative to control of environmental pollution into a single agency incorporating air, water and land resources. However, no state agency requires specific overall 
certification prior to construction of an electric power plant, transmission line or other energy-related facility.

The state Public Utilities Commission (PUC) does have jurisdiction over utility companies' securing the right of eminent domain for transmission line construction. Aesthetics is the prime consideration in these cases. The PUC decides on whether to exercise eminent domain, and the court decides the actual dollar amount of the taking. If the PUC does not approve the taking, the court will not appoint a Condemnation Committee necessary to proceed in such cases. Utilities can appeal PUC decisions to Superior Court. PUC decisions can override local zoning ordinances, but municipalities also have the right to appeal such decisions in court. Utilities in New Jersey do not have the right to exercise eminent domain for power plant sites, switching stations or substation installations.

The PUC has overall authority over power plant siting (as a result of its broad power to require"safe, adequate and proper service"), but to date such authority has not been exercised. In the 1960's the PUC did hold a hearing prior to construction of the Oyster Creek nuclear power plant in Ocean County. Such matters as air and water pollution, operating problems, zoning and financing were covered at this session. No power plant siting hearings have been held since then, although the PUC did review plans for nuclear facilities in Salem County.

Although New Jersey does not have a state energy facility siting statute, over the past decade or so the state legislature has passed a number of acts which establish criteria by which such facilities are judged and approved -- or denied. These laws are described below.

Coastal Area Facilities Review Act (CAFRA). In June 1973, the New Jersey legislature passed the Coastal Area Facilities Review Act (CAFRA). 
This stature was the culmination of a legislative effurt which had begun a year earlier, when New Jersey's interest in protecting the coastal region coincided with activities in other states - notably Delaware * and in the U.S. Congress (culminating in the federal Coastal Zone Management Act enacted in October, 1972). Much of the controversy centered around the boundary for the cuastal regulatory area.

In June 1972 , strict coastal proteciion legislation patterned after Delaware's Coastal Zone Act was introduced in the Assembly by Assemblyman Thomas kean. Although the urbanized Northeast was excluded from state regulatory control, this legislation still aroused considerable opposition. The Society for Environmental and Economic Development (SEED), comprised of organized labor, the Chamber of Commerce and other economic and commercial interests, including oil, would not accept prohibition of all heavy industrial development along the New Jersey coast. Even DEP did not approve fully of the approach taken in Kean's bill, and drafted an alternative approach.

Backed by others in the legislature, Kean substituted a new bill (written by DEP) which provided for state review of major projects in the coastal zone in lieu of outright prohibition of such facilities. Representatives from the Camden metropolitan area opposed this bill, since their jurisdictions included urban and suburban localities concerned with attracting new tax ratables. In addition, Assemhly memhers from Cumberland and Salem Counties vigurously opposed the bill. They were the most steadfast of all in their. opposition, voting to the end against all state regulation of the coast. ${ }^{28}$ These legislators represent a largely rural and undeveloped area containing some of tile most economically-depressed parts of the state. They and their constituents had hoped that deepwater port and oil refinery proposals would

* See Chapter VI, pp. 152-165. 
bring desired new revenue to their area. ${ }^{29}$ Assemblyman H. Donald Stewart (Defuocrat, Salem), contending that $75 \%$ of Salem County would come under the regulatory coverage, pushed through the amendments to exclude the Delaware River waterfront north of the Killcohook National Wildlife Refuge (south of the Delaware Memorial Bridge)..$^{30}$ These amendments satisfied the expressed opposition from SEED and from Camden, Cumberland and Salem representatives. This point comprises the southern boundary of CAFRA, thus eliminating from the legislation any state review in urbanized coastal areas. ${ }^{31}$

Monmouth County representatives as well felt the need to attract new ratables; but they were also concerned about heavily polluting industries and uncontrolled suburban residential development. The Monmouth County Planning Board developed a proposal to resolve the problem by eliminating most of the proposed coastal area south of Long Branch, leaving only a narrow strip of coastline about a half-mile wide. The county freeholders and Republican organization tronsmitted this proposal to Monmouth legislators, who amended the bill in committee. ${ }^{32}$ The bill's final change in the Assembly involved addition of areas in Middlesex County, and CAFRA passed this house by a vote of $56-8.33$

In the Senate, the labor and industry coalition expressed futther dissatisfaction even with the reduced scope of coastal regulation finally passed by the Assembly. SEED offered amendments to remove from CAFRA five specific areas where development was underway or planned: two large sections in Salem and Cumberland counties, one where the DuPont Company planned to locate new petro-chemical facilities and the other where nuclear facilities were proposed; an area northwest of Ocean City where an industrial park was planned; the western half of Cape May County, around the county airport where 
industrial expansion was proposed; and the Assembly's addition in Middlesex County, already the site of heavy industry. Pressure from labor lobbyists was so great that all the Democratic Senators abstained from voting. 34 In a compromise effort to save the legislation, Governor William T. Cahill (a Republican) and the Senate Minority Leader agreed to rescind part of the area in Middlesex County and to remove a circular area surrounding Cape May Airport. At this point, the Senate session ended. Brendan Byrne, then front-runner in the Democratic gubernatorial primary, publicly called for the Senate to reconvene and for his Democratic colleagues to vote for the coastal legislation. These combined pressures from both Byrne and Cahill weresufficient to overcome the opposition to the coastal bill. CAFRA passed in the Senate by a 28-4 vote, and, as revised, re-passed the Aseembly, 57-15. It was signed into law on June $20,19 \% 3 .^{35}$ The final CAFRA boundary is shown in Figure 1.

Since the law's effective date of September 19, 1973, DEP has been administering CAFRA. This legislation gives DEP the means to regulate -by review and approval of permit applications -- certain kinds of major developments, including energy facilities, in a 1,377 square mile area along the coast from Middlesex County on the Atlantic Ocean through Salem County on Delaware Bay. The distance this statutory coastal review area goes Inland from the sea varies from several thousand feet near Asbury Park in heavily built-up Monmouth County to 24 miles along the rural Mullica River at the southern end of Ocean County. The total area comprised in the CAF'KA zone includes almost one-fifth of the state's land area and over three-quarters of its waters. 36

CAFRA requires DEP to prepare a management strategy for the entire coastal area by September, 1977. The act also established two intermediate 


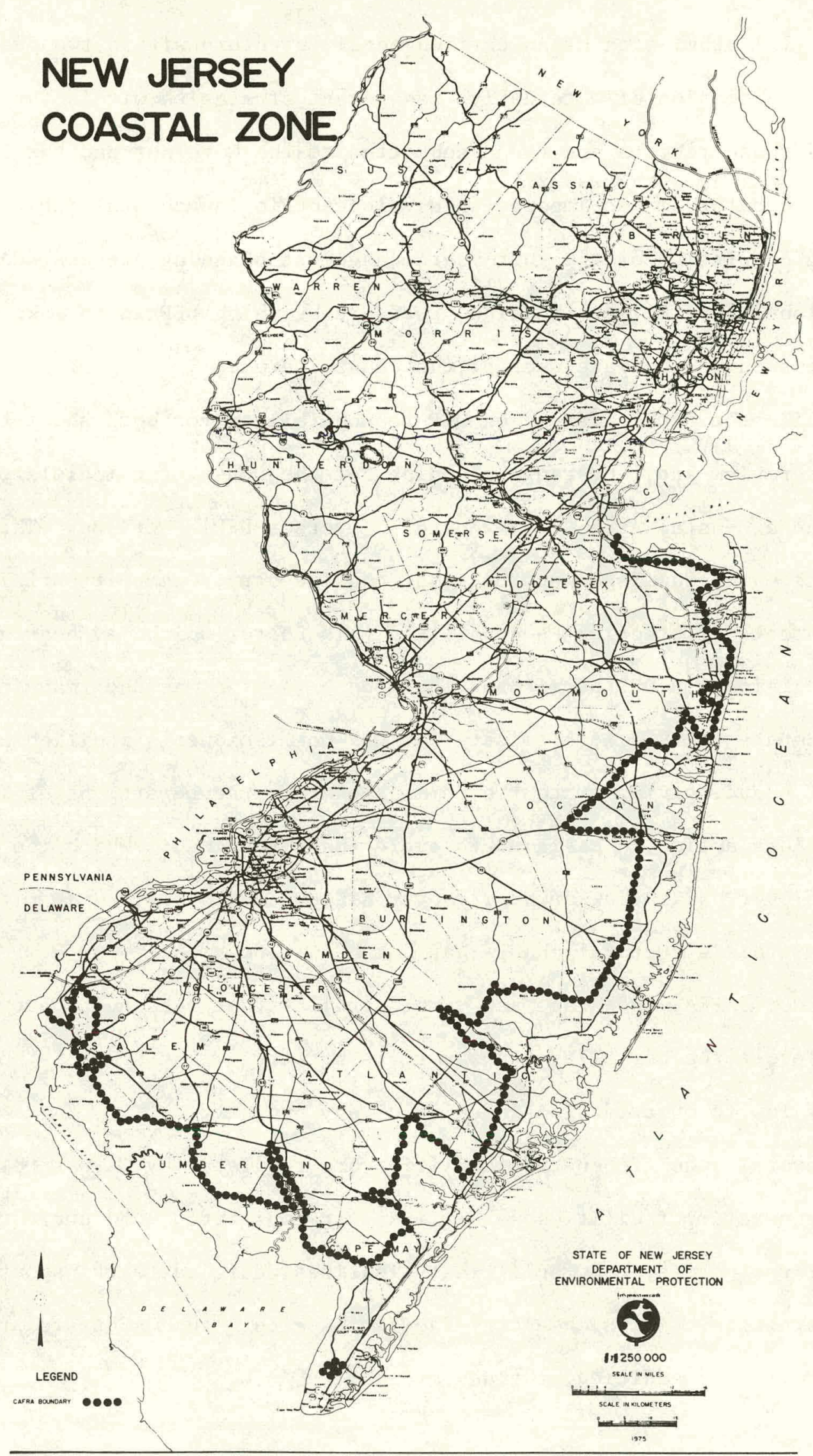

Figure I 
steps: (1) submission of an environmental inventory within two years;

and (2) submission of alternative management strategies within three years. Both of these reports are to be submitted to the Governor and the legislature.

No moratorium was imposed on development in the coastal region. Instead, pending completion of the four-year management planning process, CAFRA established a permit application procedure by which DEP is to make ad hoc decisions on appropriate uses of the coastal area.

While the act conferred on DEP responsibility for both short-term project review and long-range planning for the coast, the legislature inserted a Coastal Area Review Board to oversee DEP's actions. 'Three Cabinet officers - the Commissioners of Labor and Industry, Community Affairs, and Environmental Protection -- constitute this Board, which may hear appeals from decisions on DEP permit applications. (Action was underway in the State Senate in 1976 to eliminate the DEP Commissioner's position on the Coastal Board, giving it to the Commissioner of the Department of Transportation. This action is designed to avoid the situation in which the DEP Commissioner has review authority over his own decisions. As of this writing, this structural change has not been made.

Under CAFRA, the state may veto a project that received approval at the local leve1; the corrollary, however, is not true. The state is not authorized by law to override local denial of any project.

Several specific energy facilities are regulated by CAFRA: clcctric power generating facilities -- oil, gas, or coal-fired, and nuclear power planls; reffneries; LNG tacilities; pipelines designed to transport petroleum or natural gas. A11 such energy facilities within the CAFRA area require a DEP permit. In addition, the act states: 
"The construction and operation of a nuclear electricity generating facility shall not be approved by the Commissioner unless he shall find that the proposed method for disposal of radioactive waste material to be produced or generated by such facility will be safe, conforms to standards established by the Atomic Energy Commission and will effectively remove danger to life and the environment from such waste material." 37

Under provisions of the act, proposed facilities must conform with all applicable air, water and radiation emission and effluent standards and criteria.

The applicability of CAFRA to major energy facility siting decisions has been seen in the case of the proposed Hope Creek Nuclear Generating Station in Salem County. In November 1973, Public Service Electric \& Gas Company (PSE\&G) proposed to construct this facility at Artificial Island, on the east bank of the Delaware River in Lower Alloways Creek Township of Salem County, adjacent to the Salem Nuclear Generating Station under construction prior to passage of CAFRA. ${ }^{*}$ Hope Creek was to be a replacement * In another controversial case where the "grandfather clause" of commencing
construction prior to CAFRA's effective date became a prominent issue, DEP
Commissioner David J. Bardin decided in December 1976 that the Jersey Central
Power \& Light Company could continue to construct its Forked River nuclear
power plant, the second in. Ocean County. The Oyster Creek nuclear plant in
the county is also operated by JCP\&L. (See proposed legislation on this fac-
ility, pp. $47-48$ ), The Commissioner, as the final adjudicator, overruled his
Department's Division of Marine Services to accept the opinion of a former
state Supreme Court justice who was named a special hearing officer to deter-
mine if CAFRA was legally involved in regulating this project. Bardin's major
considerations were that site preparation and other work on the facility had
begun well before CAFRA was passed, and that large sums of money had already
been spent on the project. In hearings on the matter, the state Attorney
General's office, representing the Division of Marine Services, agreed that
site preparation had begun but contended that no municipal building permit
had been issued prior to such work. The Attorney General's office also
argued that JCP\& had lost its claim to 3 omemption from CAFRA because of
undue delay in completing construction.

In addition, the state Public Advocate urged that the facility be subject to CAFRA regulation, and argued that site preparation had been insignificant when CAFRA took effect. The Public Advocate also pointed to previous decisions which did not exempt projects involving housing and commercial development having less significance than a nuclear power plant. 39 
for the Newbold Island site on the Delaware River between Philadelphia and

Trenton which had been rejected in the licensing process. This was the

first (and as of June 1976, the only) energy facility to apply for location

in the statutory coastal area since passage of CAFRA.

The DEP Commissioner conditionally approved a CAFRA permit for Hope

Creek in a September 1975 decision. In this approval, the following import-

ant points were made:

"Given the statutory goals, the coastal area should not be dedicated predominantly to construction of additional energy facilities. Neither should such facilities be totally banned. Rather, carofully limited portiono of the coaotal arca should be made avail able for needed energy facilities. Such portions should be delineated to minimize impacts on the prime recreational zones and also on significant biological resources. 140

With regard to distinctions between federal and state jurisdiction over

nuclear facilities, this document noted:

"PSE \&G argues that Congress has preempted the states from exercising authority in the area of radiological health and safety and related topics in connection with nuclear power generating stations. Northern States Power Co. v. State of Minnesota, 447 F. 2d 1143 (8th Cir. 1971), affirmed 405 U.S. 1035 (1972). In contrast, New Jersey PIRG (Public Interest Research Group) argues that other doctrines do allow DEP to exercise authority over at least certain of these questions... .

Wholly apart from these questions, however, it is undoubtedly within the jurisdiction of DEP under CAFRA to determine many major issues, such as where in the coastal area a nuclear power generating station may or may not be sited, or the conduct of certain activities related to the facility (e.g., portions of the fuel cycle or the role the facility plays in energy supply) to ensure that all such facilities are constructed and operated in a way that serves the best long-term social, economic, health, environmental, recreational, aesthetic and other interests of the citizens of New Jersey." 41

DEP's decision on Hope Creek has been contested in court by the New

Jersey Public Interest Research Group (PIRG), a student-funded citizens 
group based in Trenton. PIRG contends, among other things, that Commissioner

Bardin failed to comply with the section of CAFRA on radioactive wastes

quoted above. A report from the New Jersey League for Conservation Legis-

lation commented on these issues in this manner:

"Environmentalists consider this requirement to be a de facto ban on any nuclear power plant construction, since a safe way to handle these highly toxic wastes has yet to be devised. In granting the permit, the Commissioner, in a narrow interpretation, claimed that Section 11 only applied 'insofar as it (the waste disposal) takes place within the State of New Jersey.' The Commissioner did not make the necessary finding that the disposal of spent fuel rods will be done in any environmentally safe manner which 'effectively remove(s) danger to life.' Instead, he was satisfied with a promise on the part of PSE\&G to supply that information in the future." 42

The issues of radiation and radioactive wastes were addressed further

in DEP's "statement of conditional approval" for the Hope Creek facility:

"PSE\&G shall continue the Salem radiation monitoring program for the Hope Creek Generating Station and further will institute an immediate radiation reduction or clean-up program if any adverse radiological impact occurs as determined by DEP....

DEP bans the use of mixed uranium/plutonium oxide fuel rods in the Hope Creek facility. The applicant may at a later date petition for an amendment to allow the use of plutoniummixed oxide fuel rods; the petition for such an amendment will be considered on its merits at that time and will be based on then existing state and federal laws and regulations as well as on the then-current scientific and technical knowledge of plutonium toxicity, diversion possibilities, safeguard and transportation hazards, and other pertinent factors." 43

In its April, 1973 réport, the Ad Hoc Committee on Energy and the En-

vironment of the New Jersey Senate had observed that:

"Although it is not proposed that waste be buried in New Jersey, we cannot pass this matter off as a problem for another state. Radiation, once released, like any other form of pollution, does not observe political 1ines. In any event, the Committee is concerned about the safety of people and the protection of our environment everywhere and recognizes that this is a social question national in scope. 44 
PIRG contends that the DEP Commissioner, in considering the effects of nuclear waste disposal on New Jersey in the Hope Creek decision, was interpreting the legislative intent of CAFRA only very narrowly, in contrast to the Ad Hoc Committee's statement and to the fact that the Committee's recommendations caused amendments to CAFRA on the Senate floor pertaining to review of waste disposal procedures in reaching CAFRA decisions on siting any nuclear plants in the coastal zone. 45 As of January 1977, the FIRG suit was still pending before the court.

CAFRA's relevance to nuclear power plant siting remains clouded in disagreements over federal preemption vs. states' rights. In a federal/ state dispute which emerged in 1976 , a top official of the Nuclear Regulatory Commission (NRC) contradicted a claim that New Jersey has sufficient legal authority to block construction of nuclear power plants at locations the state considers unsafe. The NRC official contended that the federal agency is the only government body at any level with the authority to reject plant sites on considerations specifically related to radiological health and safety. DEP Commissioner Bardin has argued that his Department has the final say on nuclear power plants under rights granted by CAFRA and other state laws. Bardin said he would withhold state approval. from a PSE\&G proposal to locate two floating nuclear power plants off the Atlantic City coast until additional safety studies had been made. The NRC claims that the state can advise the federal government concerning environmental and need factors, but that only it (NRC) issues the formal construction permit. 'lhe NKC asserted that the state can take its objections to a federal appeals board and, if it were turned down there, could take the matter to the federal courts. 46 
CAFRA has a number of limitations as well as some evident strengths. While the act is the state's prime device for influencing and regulating energy facility siting in the coastal area, it is basically a reactive mechanism limited to a defined -- albeit critical -- geographical area. Other legislation already proposed in the New Jersey legislature, (discussed later in this Chapter) would address the facility siting dilemma in a more comprehensive manner, thus augmenting CAFRA. Moreover, other existing acts provide various types of additional state regulatory influence over energy facility siting.

Coastal Wetlands Act. This statute, enacted by the legislature in November 1970, in many ways was the precursor of CAFRA. It too is implemented by DEP and may affect siting of energy facilities.

The Wetlands Act requires DEP to inventory and map a11 tidal wetlands within the state. The boundaries of such wetlands are to generally define those areas at or below extreme high water (although lands subject to the jurisdiction of the Hackensack Meadowlands Development Commission are specifically excluded). After a public hearing, the DEP Commissioner may adopt, amend, modify or repeal orders regulating, restricting or prohibiting dredging, filling, removing or otherwise altering or polluting coastal wetlands. Anyone proposing to conduct a regulated activity in the wetlands must file an application for a permit with the Commissioner, who must consider the effects of the proposed work with reference to public health and welfare, marine fisheries, shell fisheries, wildlife, and protection of life and property from flood, hurricane and other natural disasters. Application of the Wetlands Act to energy facility siting is seen in the case of the March 1973 proposal by the Jersey Central Power and Light Co. (JCP\&L) to construct an oil-fired electric generating plant in the Union Beach area of Middlesex County, on Raritan Bay. Although a public 
hearing under the Wetlands Act was held on this application in September 1973, nothing has transpired since, and the proposal was still pending as of September 1976. JCP\&L subsequently has decided to look to coal rather than oil, and switched the proposed plant location to Pennsylvania to be closer to its fuel source. Meanwhile, demand for the Union Beach site was pushed back to the $1990^{\prime} \mathrm{s}$. Thus, the application is dormant. 47

Flood Plain Law. New Jersey also has a Flood Plain Law, passed in 1962 and substantially amended in 1972. This legislation gives DEP authority to adopt rules and regulations concerning development and use of land in any designated floodway so as to preserve its flood-carrying capacity and to minimize any threat to public safety, health and welfare.

Under this legislation, within specified time periods the affected municipality or other responsible entity must adopt regulations concerning development and use of land in the flood fringe area which at least conform to the minimum standards promulgated by DEP. If the municipality fails to adopt or enforce adequate rules, DEP may adopt such rules and regulations. Regulations more restrictive than thocc adopted by DEP may be applied locally. Obviously, any energy facility proposed for a flood-prone area would have to culsurm to the applicable state or local standards.

Riparian Statutes. The federal Submerged Lands Act of 1953 granted to the states jurisdiction of the seabed out to three miles offshore, and allowed the states to exercise all of their common law and public trust powers. These include authority over riparian lands, where New Jersey is a proprieter as well as the regulator. *

$$
\text { * }
$$

* The state holds title to riparian lands as trustce for the public. New Jersey is the only state where such authority extends to all lands "now or formerly flowed by the tides." In other states publ1c water interests extend only to all waters that are navigable. 48 
Under state riparian law, any proposal for construction of a facility on lands of the state now or formerly flowed by the tide (riparian lands) must be approved by the State's Natural Resources Council, a 12-member body within DEP's Division of Marine Services whose members are appointed by the Governor with the advice and consent of the state Senate. This Council is the initial agency for review of applications for riparian grants and leases. Additionally, unless the subject lands have previously been conveyed by the Council (or its predecessors), a grant or lease must be obtained in exchange a consideration equivalent to "fair market value". Before the Council can permit the development of riparian lands, it must determine that the proposal will be in the public interest. After the grant or lease is approved by the Natural Resources Council, it must also be approved by the DEP Commissioner and the Governor. ${ }^{49}$ The Secretary of state and Attorney-General sign the document as attesting witnesses. 50

Control of riparian lands may well become the single most powerful instrument available to the state to influence energy developments, particularly in those areas of strong federal pre-emption. However, since the Natural 'Resources Council is not authorized under New Jersey's existing riparian statutes to make grants of land seaward of the pier and bulkhead line, ${ }^{5 I}$ special legislation may be required before PSE\&G can construct its proposed floating nuclear power plant at the Atlantic Generating Station. This would also appear to be the case for any oil or gas pipelines entering New Jersey's waters from the Baltimore Canyon Trough Outer Continental Shelf area.

In connection with riparian law, there has been recent heightened interest in New Jersey and elsewhere in the public trust doctrine which stems from early English common law derived from the Magna Carta in 1215. 
This doctrine protects the public's right to navigation and fishing in lands flowed by the tides. 52 This law bound Charles II when he granted the territory of New Jersey to the Duke of York, who became the protector of all tidal lands for the common use. This role of trusteeship was passed on to the states after the American Revolution. 53

In New Jersey, recent court decisions on the issue of beach access have re-focused attention on this ancient doctrine. In a 1972 case (Borough of Neptune City v. Borough of Avon by the Sea), the court determined that the public trust doctrine was not static, but should be adapted to meet changing conditions and needs of the public which it was intended to benefit. The opinion in this case noted that although the scope and limitations of the doctrine in New Jersey had never been defined precisely, the doctrine involves the inherent right of the citizenry which cannot be disputed. The court observed that other states have readily extended the public trust doctrine beyond its original purposes of navigation and fishing to include other public uses, particularly those which are recreational in nature. 54 This doctrine is also being examined in connection with federal pre-emption over regulation of nuclear power facilities, particularly in relation to CAFRA. 55

Pinelands Act. The state's Pinelands Act, passed in 1972, might also affect energy facility siting, at least in this particular area. This act established the Pinelands Environmental Council (PEC) to engage in comprehensive planning tor 320,248 acres of predominantly undeveloped land in Ucean and Burlington Counties. Much of this land is in the state-owned Wharton Tract (state forest). A total of 167,718 acres, however, remains as vacant land in private hands, potentially developable but in an environmentallyfragile condition. 56 
The PEC is a planning and advisory body rather than a regulatory agency, and is charged with protection of the water resources and other natural...assets. of the area. The Council is directed to "encourage compliance with the plan by all public and private agencies and persons." It seeks to protect the area by restricting activities to limited recreational purposes, or to highly specialized types of farming which do not disturb the delicate ecosystem. Although the Council does not have direct enforcement authority, it can review and comment on each project which presents a substantial risk to the Pinelands environment, unless the development is needed as an emergency action for protection of life or property. The PEC thus can delay the start of a project by up to 90 days, holding public hearings and disseminating any negative findings in an effort to block undesired projects. 57 However, the PEC was not funded by the state in 1975 and 1976 , and thus may pass out of existence for all practical purposes.

In December 1976 at an all-day seminar on the Pinelands at Princeton University, Governor Byrne called for measures to preserve this area from over-development. He repeated this call in his January 1977 state of the State address to the legislature. ${ }^{58}$ State officials have pointed out the value of the Pinelands as the largest unspoiled area remaining in the Middle Atlantic Seaboard region and as an area containing an aquifer which is the largest source of unpolluted water in the country.

Hackensack Meadowlands Development Commission (HMDC). This commission was created by the state legislature to give special attention to the "ecological factors, air and water pollution, waste disposal and the protection of the balance of nature that could be adversely affected by artificially imposed development." The Commission, formally administered within the. 
Department of Community Affairs, transcends municipal boundaries, covering all of part of 14 municipalities. A committee representing municipal interests "acts in concert" with the Commission to "plan, develop and re-develop the Hackensack meadowland." 59

HMDC is unique because it is a state-initiated regional planning body endowed with sweeping authority in its area. It has been given all powers of zoning and planning in the area normally granted only to municipalities, and at the same time it performs some of the functions of several state agencies (e.g., DEP and the Department of Health). Innovative tax-sharing measures apply to a11 new ratah1es.

Issues in State/Local Land Use Control. Over the years, the pendulum of control. over land planning in New Jersey has swing back and forth between state and local control. The state exercised control -- such as it was -over land use decisions until the early part of the 20 th century, when these powers were delegated to the 567 local municipalities. ${ }^{60}$ These local governments encompass the entire state with zoning regulations and home rule attitudes.

Commencing with the Earth Day ethic of 1970, concern over environmental issues lud to a reversal of that trend; direct state regulation was added as a supplement to local action in areas considered to be of critical ecological importance. CAFRA and other state land control laws did not give the state override power on a.l,1 local land decisions. Current state laws can prevail only where the project in a regulated area first has received local approval, in which case the state can deny a permit. Converocly, if a local agency rejects a project which the state feels should be built, the state has no power to grant approval over the local agency's objections. This could change for major developments, including energy facilities, however, if the proposed Development Review Act (discussedbelow) were enacted. 
Various other state laws have some relevance to energy facility siting decisions in New Jersey, including:

Air Pollution Control Act

Noise Control Act

Solid Waste Management Act

Stream Encroachment Act

Waste Control Act

Water Control Acts

Water Quality Improvement Act. 61

In an assessment of the state's ability to deal with ocs related onshore

development, a Deputy Attorney General's report to the Cabinet Energy Committee

in February 1976 concluded:

"Pipelines headed for refineries in the Philadelphia area may very likely pass through the PIne Barrens of Burlington and Ocean Counties... With this exception the state would appear to possess sufficient authority to regulate and prevent undesired development in its coastal zone... New Jersey's biggest challenge will be to coordinate all of its responsibilities - regional, state and local - in an effort to monitor and respond to the initiatives of industry and the federal government. In order to meet that challenge, New Jersey must begin effective planning in the near future. 62

Miscellaneous Energy-Related Legislation

A commission was created in August 1975 to review the effectiveness of the Board of Public Utilities Commissioners in protecting the public interest with regard to the supply and price of electricity and natural gas in the state. The ten commission members were to be appointed as follows: three menbers of the Senate and two public members to be appointed by the President of the Senate, and three members of the General Assembly and two public members to be appointed by the Speaker of the General Assembly. No more than two Senators and two Assemblymen can be members of the same political party. ${ }^{63}$ Although this Commission was formed, like the Energy Crisis Study Commission it too has not been active to date. 
The State Uniform Construction Code, signed into law in October 1975 , empowers the Commissioner of Community Affairs to promulgate a statewide building construction code. 64 When adopted, this code will supersede a myriad of existing local and state codes of varying age and containing diverse standards. The new state code is to be composed of component subcodes such as: building, electrical, plumbing, energy, fire prevention, and so on. These were to be promulgated in 1976 and be effective by the target date of January 1, 1977. * The energy subcode, probably to be based on ASHRAE standards, would foster energy efficiency and include standlats for insulation and related materials. 65

\section{Proposed Legislation on Energy Policy}

As of September 1976 the New Jersey legislature was faced with a vast backlog of energy legislation, much of which was introduced in. the 1974 legislative session at the height of the energy clisis and reintroduced in the 1976 session. 66 The deadlock over tax reform, lack of legislative mandate, absence of pressure from any organized political constituency, and other political issues have precluded forward movement of any of this legis 1ation, and most of the bille discussed in this eection remalu tabled in various legislative committees. Nevertheless, the large amount of entrgy legialation which has been introduced, and its variety, suggest a degree of initiative on the part of individual legislators which is not evident if one looks only at passage of these bills into law. Moreover, this existing backlog of energy legislation suggests that -- once nther priorities are cleared away -this state leoislature might move forward rather ranluly to cups with New Jersey's manifold challenges with respect to energy policy.

$\bar{\not}$

Completion of the energy subcode has been delayed beyond this date. $* *$

The Spill Compensation and Control Act (relating primarily to oil spills) was signed into law on January 6, 1977. 
State Energy Facility Agency. A major energy facility siting bill was introduced in the Senate in April 1976.67 This bill would create a State Energy Facility Agency (SEFA) to plan and regulate the location, operation and maintenance of energy and energy-related facilities (including petrochemicals, offshore oil and natural gas, and their attendant operational support facilities). Principal sponsors of this legislation are Senators Frank Dodd and Joseph McGahn. If adopted, this bill would give New Jersey a structure and framework for statewide energy planning and regulation equal to that of any other state in the nation.

Energy facilities would be located "in energy parks wherever practicable," and would be surrounded "wherever feasible" by buffer areas of dedicated open space or other non-residential and low-density land use. * SEFA would be a "one-stop" approval agency, with authority to administer a permit process replacing the present system of multiple permits issued by DEP and other state and local agencies. The new agency would be established in, but not be a part of, the Department of the Treasury.

Ex-officio members of SEFA would consist of the State Treasurer as Chairman, the President of the PUC, and the Commissioners of Community Affairs, Environmental Protection, and Labor and Industry. Six additional members would be appointed to three-year terms by the Governor, with the advice and consent of the Senate.

* On March 10, 1976, DEP Commissioner Bardin declared a temporary building moratorium in a four-mile buffer zone around the state's only operating nuclear power plant -- Oyster Creek, in Ocean County -- and around the Salem site where two additional reactors are under construction. This moratorium, enforced under CAFRA for developments of 25 or more dwelling units, is to remain in effect until DEP has completed studies of potential hazards and optimal land use patterns in the vicinity of nuclear generating stations. 68 
A comprehensive on-going program of study and research into the environmental, social, economic and technical aspects of energy facility development would be undertaken by the new agency's staff. SEFA would conduct

-. (either directly or by way of contract, grant, or other arrangement) a continuing research program, to include:

-general biological and ecological baseline studies of the state's air, water and land resources;

-monitoring of existing and future energy facilities for their effect upon the environment;

-studies evaluating potential sites for energy parks and energy facilities;

-studies of the potential for constructive use of waste energy released at proposed sites;

-analysis of the socioeconomic impact of energy facilities on land uses and transportation infrastructure of the state;

-studies of programs to induce the public to conserve energy and of other conservation measures.

All energy-related industries would be required to engage in longrange planning, with such plans being made available to the public for review and comment prior to their implementation. Each industry would submit to SEFA at three-year intervals an updated 25-year Energy Facilities Plan, containing comprehensive information on:

-location, size, capacity and type of all existing energy facilities owned or operated in the state or to be constructed or withdrawn from opcration during Llie uexL 25 years;

-analysis of the potential adverse effects of such actions.

The act would ensure that SEFA also received necessary information from the various state agencies concerned with energy facility siting. DEP would be. required to identify appropriate locations for energy facilitles within the CAFRA coastal area, and to formulate guidelines for SEFA to use in determining the environmental suitability of energy facility sites. In addition, the Departments of Labor and Industry and Community Affairs would advise SEFA on the projected need for various energy facilities and on population growth and Tand use. 
Within one year of the effective date of the proposed act, SEFA would publish a statewide Energy Facilities Plan based on information received from industry, state agencies, and others. Prior to inclusion of any site in the inventory of approved sites, and before approval of the overall plan, a full public hearing process is stipulated. Final approval of the plan would remain the prerogative of the legislature.

The act provides for state acquisition of necessary energy facility sites through its powers of eminent domain; however, this process is to be used only when an industry first has sought unsuccessfully to acquire a site, and only after agreement with the land owners regarding compensation. Agricultural lands are to be avoided wherever possible.

SEFA would have to issue a Certificate of Site and Facility prior to construction of any new energy facility in the state. This approval would supersede all local requirements. The certificate would have to be accompanied by an environmental impact statement and a plan for monitoring environmental effects of the proposed facility, with provision for remedial action if necessary. Conformance with the state's Wetlands, Flood Plain and CAFRA laws is required under the proposed bill. There is provision in the act for permit fees to be paid by industrial applicants, penalties for non-compliance, and judicial review; an appropriation of $\$ 250,000$ would be made to SEFA to cover its first year of operations.

This is the most comprehensive energy facility siting legislation proposed to date in New Jersey, and its passage would represent an important step forward in state control of high-impact energy facilities. 'It is a bold departure from the planning vacuum for energy facility siting which exists at present in New Jersey, and constitutes a major challenge to home 
rule traditions through SEFA's proposed state override authority. While the state would evaluate those sites applied for by a utility, the act does not provide for: prior state acquisition of sites to be held in a "site bank," nor for a broad-based funding mechanism for research as does the Maryland law (see Chapter III) and the proposed New Jersey legislation discussed below.

Energy Facilities P1anning Commission. In 1972, Assemblyman Kean introduced a bill in the Assembly to create an Energy Facilities Planning Commission to conduct state planning for construction and location of power plants. ${ }^{69}$ Kean has a record of strong environmental advocacy in the New Jersey legislature. This bill would place the new commission in DEP, calling for it to conduct a continuing research program concerning the environmental, social, economic and technical aspects of bulk power supply facility development and to evaluate the environmental and land use impacts of existing and future facilities. The commission would review site applications and issue Certificates of Site and Facility for construction of all electric generating plants.

l'his bill, still active in the Assembly committee, contains provisions for public hearings prior to acquisition of each site. It would also establish an Energy Facilities Trust Fund financed by a surcharge on electric bills -- $\$ 0.0003$ per kilowatt hour -- to achieve the purposes of the planning comnission.

In several ways, this bill was the precursor of the Senate's SEFA legislation introduced four years later; some identical language is used in the SEFA bill. However, the two bills differ in several important respects. The Kean Bill has some innovative features similar to the Maryland Power Plant Siting Act of 1971, especially in prior state acquisition of sites 
and establishment of a fund to acquire sites and to carry out an intensive research program to study the environmental and other impacts of energy facilities. However, it is more limited than the Dodd/McGahn Bill in that it covers only power plants (e.g., it.excludes those energy facilities- related to offshore oil and gas operations). In addition, the Kean Bill makes no specific provision for buffer zones or "energy parks". CAFRA Amendments

Three bills have been introduced in the Senate to amend CAFRA. Although none deal explicitly with energy facilities, the proposed changes would affect CAFRA's impact on siting. One bill, which passed the Senate in 1976 and awaits Assembly action, would alter the composition of the CAFRA Review Board. 70 The Commissioner of Transportation would replace the DEP Commissioner, and two citizen members would be added to the Review Board. 'In effect, this amendment would eliminate DEP review of its own decisions on CAFRA applications. A second bill introduced by Ocean County Senator Russo would increase the review threshold for residential subdivisions under CAFRA from 25 dwelling units to 50. 71 This could be significant in the use of CAFRA permit decisions to maintain low-density buffer zones around nuclear power plants. 72 The third bill, also sponsored by Senator Russo, 73 would exclude from CAFRA regulation all land west of the Garden State Parkway in the Ocean County townships of Lakewood, Dover, Manchester and Jackson.' This would eliminate roughly 60 square miles (or approximately 4.5\%) from the jurisdiction of CAFRA, 74 and is seen as a move to lessen barriers to development in an area which already is partially developed. ${ }^{75}$

\section{Nuclear Moratorium}

The Nuclear Reassessment Act was introduced in the Senate on May 19,1976, by Senator McGahn, a physician from Atlantic City which is 12 miles from 
the site of the proposed floating nuclear plants. ${ }^{76}$ McGahn is a member of the Senate Committee on Energy and the Environment. This bill would impose a four-year moratorium on construction of nuclear power plants and related facilities, including those used for storage of radioactive fuels and wastes as well as facilities "for the conducting of operation and maintenance activities for offshore floating nuclear fission power plants." The legislation was drafted by the New Jersey Public. Interest Research Group.

This bill is based on features contained in the California initiative (Proposition 15) rejected by the voters of that state on June 8, 1976; it also has some similarity to legislation which became law in California in May 1976 (the three Warren bills). The proposed New Jersey ban would be lifted after four years if the following conditions were met:

(1) legal owners of nuclear power plants must guarantee that those suffering personal injury, property danugc, or itles economic loss as a result of the escape or diversion of radioactivity from their plantswill be fullycompensatcd (i.e., waiver of the Price-Anderson Act);

(2) nuclear power generation is proven to be the best means of meeting future energy demands;

(3) evacuation plans in the event of an accident or threalened accident are deemed sufficient to protect life and public order;

(4) safety systems built into nuclear facilities are demunstrated to be effective;

(5) radioactive wastes from such plants can be safely transported, stored and disposed of.

Determination that these various conditions had been met would be made by the state legislature, following a formal review process by an advisory group cunsisting of tour members of the legislature and three individuals to be appointed by the Governor, one each from the State Energy Office, the utility industry, and a "citizen group dedicated to protecting the public from nuclear hazards". If the conditions set forth in the legislation were not met within one ycar after passage of the law, any nuclear power plant in New Jersey would have to be operated at less than $60 \%$ capacity. If the same conditions 
still prevailed four years after the effective date of the law, nuclear power plants in the state would have their power reduced ("derated") at $10 \%$ per year from their $60 \%$ capacity. Since Senator McGahn has stated that passage of his bill hinged on the California vote, ${ }^{77}$ defeat of Proposition 15 thus may affect the fate of his bill (or similar legislation) in New Jersey. The bill is still pending in the Senate. Other Nuclear Safety Legislation

Concern about safety factors at the Oyster Creek Nuclear Generating Station in Lacey Township, Ocean County, prompted Assemblyman C. Gus Rys (Democrat , Bergen County) to introduce a Concurrent Resolution in May 1976. Calling for formation of a legislative commission to investigate incidents which have occurred at the Oyster Creek plant, the resolution states:

\begin{abstract}
"During the year 1974, the Oyster Creek Nuclear Generating Station (OCNGS) had been closed for about 10 weeks when leaks were discovered in its cooling system during a shutdown for refueling;
\end{abstract}

In January, 1975, the OCNGS was one of 23 in the nation ordered to shut down operations by the federal Nuclear Regulatory Commission and to inspect emergency safety system pipes for possible cracks;

During the year 1975 an increasing number of condenser tubes developed leaks allowing sea water to contaminate the water circulating in demineralizer units at the plant." 78

The commission would report its findings and recommendations to the legislature. This legislation is awaiting floor action in the Assembly. Another expression of concern over nuclear safety is embodied in a bil1 introduced in June 1976 by four Assemblymen to mandate preparation of contingency plans to be implemented in the event of a nuclear accident. 79 The required plans would detail procedures for the evacuation, 
when necessary, of people in regions exposed to hazardous amounts of radiation. The bill is in the Committee on Judiciary Law, Public Safety and Defense. *

Development Review Act

On January 19, 1976, legislation was introduced in the Senate on behalf of the Byrne Administration to establish a Development Review Agency (DRA).80 This agency would carry out activities related to planning and review of large-scale land use decisions; essentially it would be a state land use agency. The act would also streamline the overall stale development review process. Governor Byrne has designated this bill as one of his legislative priorities for $1976-77$.

Under the proposed Development Review Act, a three-person agency, appointed by the Governor, would serve as an appeals body for disputes involving large development projects with a "regional impart." Any applicant whose "major development" proposal was rejected at the municipal lovel could appeal to the state board. If the,board found the plan consistent with state goals, it could order the municipality to issue a building permit.

The bill states:

"The legislature finds and declares that there is a need to manage land development in New Jersey in a manner which encourages desirable economic growth and the creation of employment opportunities, promotes efficient energy management, satisfies basic shelter needs, expands housing opportunities, supports efficient utilization of public or public-aided transportation and other capital facilities, and protects the land, air, water, natural resources and environment of New Jersey; and to provide procedures by which the State may share responsibllity with local government for the approval of major development with regional and statewide impact."

* In November 1976, DEP released its proposed plail on emergency responses to possible nuclear power plant accidents. The plan, called "Procedures for Implementing Protective Action Guide"(PIPAG), call's for a series of responses to nuclear emergencies ranging from simple monitoring to mass evacuation. Public hearings on the plan are expected early in 1977. 
Energy facilities to be regulated under the major development designa-

tion are described as:

(1) Any proposed petroleum or other energy source production or storage facilities or combination of related facilities, including liquified natural gas and synthetic natural gas facilities with a storage capacity of 50,000 or more barrels or any addition to such a facility with a storage capacity of over 50,000 barrels, except that in the case of liquified natural gas the size criterion is 30,000 gallons of storage capacity and in the case of synthetic natural gas the size criterion is 10,000 cubic feet of production capacity per day. (A.barrel equals 42 U.S. gallons). A "combination of related facilities" exists whenever different facilities or sections of a facility are connected by a petroleum or other energy source pipeline, and such a combination is a major development if any single part of the combination meets the size criteria specified.

(2) Any proposed electrical generating facility with a generating capacity greater than 100 megawatts, or a proposed addition to an existing electrical generating facility which has a generating capacity of greater than 100 megawatts, except that this provision will not apply to a facility which produces electricity not for sale to others.

Guidelines developed by the DRA for major petroleum or other energy

production or storage facilities must address the following factors:

(1) the risk of water pollution from spills and leakage;

(2) the anticipated air pollution from refinery emissions and the escape of fumes from processing and storage facilities;

(3) the risk of a hazardous fire;

(4) aesthetic blight;

(5) the effect of such a facility and of subsidiary development on the environment and the character of the area, including the character of an agricultural area;

(6) the locational and ecological characteristics of the kind of site required for such a facility;

(7) the contribution of the facility to the satisfaction of the energy needs of the state and to efficient energy management;

(8) the contribution to the expansion of employment opportunities; and

(9) the contribution to economic growth.

The act would allow for an appeal or petition to the PUC if a utility company were aggrieved by the actions of a munlcipality. If the PUC found the present or proposed use of the land by the public utility to be necessary 
for the "service, convenience or welfare of the public," the utility could proceed in accordance with the PUC's decision, thereby over-riding the wishes of the local government.

The Development Review Act would also amend the existing CAFRA legislation. The proposed DRA would replace the Coastal Area Review Board and would hear appeals from the Department of Environmental Protection's CAFRA permit determinations. The new independent agency, in consultation with DEP, would apply its own guidelines in the CAFRA coastal area.

This legislation is significant because of the extensive regulatory authority it would provide to the uew agency over major development projects, including energy facilities. This authority, superseding existing state departmental and municipal responsibilities, accounts for the difficulty encountered by the Byrne Administration in finding a sponsor for the bill, and for the largely negative reaction of many departments of state government to the Development Review Act. The positive authority granted the Development Review Agency to over-ride municipal vetoes of proposed facilities would be a major alteration of the plesent situation, and passage of this bill clearly would constitute a strong reversal of New Jersey's home rule tradition.

Structural Changes: The State Energy Office and Other New Entities

Two almost identical bills have been introduced in the senate to renew the statutory basis of the State Energy office, which expired in June 1975. One of these bills ts being sponsored by the Senate President, Senator Mathliew Feldman (Democrat, Rergen County); ${ }^{81}$ the other is being sponsored by the immediate past Senate President, Senator Dodd. 82

As noted earlier in this chapter, a dispute arose in 1975 between the Governor and some legislators as to the proper jurisdictional location for the Energy Office. The proposed legislation would assign the Energy office 
to the Department of Law and Public Safety (as opposed to the PUC, where it is currently located under Executive Order); however, the Energy Office would be independent of any supervision or control by that Department. An SEO Administrator would be appointed by the Governor with the advice and consent of the Senate. The functions of the office, as reconstituted, would include :

- design of a state energy master p.1an

- establishment of an energy information system

- design,implementation and enforcement of a program for energy conservation

- monitoring of prices charged for energy within the state

- conduct of research for energy efficiency, developing new sources, etc.

- adoption of an emergency allocation plan

- reduction of the use of energy and establishment of priorities for distribution in emergencies.

These bills also would empower the Governor to proclaim by executive order a state of energy emergency for a period of up to six months.

Since the State Energy Office has not functioned as the comprehensive energy planning agency it was meant to be, passage of this legislation could change that circumstance, thus helping New Jersey prepare to cope with its current and future energy problems.*

An alternative approach is contained in a bill which would establish a Department of Energy in the executive branch of state government. The current. State Energy office would be transferred to this new department. ${ }^{83}$ In addition, this bill calls for creation of an Advisory Council consisting p one representative each from the PUC and the consuming public. This legislation incorporates much of the wording of the previously described Energy

Fhis measure passed in the Senate 29-0 in January 1977 and awaits assembly action. Since the issue of the locus of the SEO has not been resolved with the Governor, it is uncertain what his actions will be if the bill reaches his desk. 
Office bills, but includes considerable formal energy industry inputs via the proposed Advisory Council.

Creation of a New. Jersey Power Authority would be accomplished by a bill introduced in the Assemb1y. ${ }^{84}$ This agency would be located in, but not of, the PUC. It would be designed to facilitate expansion of electric power in the state through acquisition of land, construction of facilities, financing, extension of 1oans, and so on.' The Authority would have all the usual powers to float bonds, condemn property, and so forth. It would have on its Board the President of the PUC, the Commissioners of Labor and Industry, Environmental Protection, and Community Affairs, the State Treasurer, and additional members appointed by the Governor. This legislation, although introduced to facilitate construction of power plants, is a piecemeal approach to this problem; no reference is made to land planning, environmental considerations or siting of other energy facilities.

An Energy Master Plan Commission, consisting of four members of the legislature and seven citizens to be appointed by the Governor with the advice and consent of the Senate, would be created under a bill introduced In Aprit, 1976 by Senator Raymond Bateman. 85 This Commisoion's function would be to plan for the state's long-term energy needs; it would subsume some of the functions of the Energy Crisis Study Commission and duplicate the most recent proposals to broaden the dutles of the Etate Energy Office.

A bill introduced in the Assemb1y by Assemblyman Van Wagner would establish a fuels supply reporting system. ${ }^{86}$ This bill, a direct response to the 1y/3-74 energy arisia, refers to the "currently existing critical shortage of motor fuels" and attempts to deal with the gasoline supply question which plagued so many decision-makers during the crisis. Another direct response to the 1973-74 crisis was introduced by Assemblyman Orechio (Democrat, Essex County) in 1975, when he called for creation of a commission 
to study the "current" fuel energy crisis to determine its intensity, severity and possible duration. ${ }^{87}$ This Commission was to seek both immediate and long-term solutions.

Federal actions on energy were looked to in a resolution introduced by Assemblyman John Doyle. (Democrat, parts of Burlington, Monmouth and Ocean Counties). His resolution would call on the President, the Congress and the Administrator of the U.S. Energy Research and Development Administration (ERDA) to establish a National Energy Research and Development Center as the central headquarters to coordinate and direct all energy research conducted by or for the federal government. 88 A New Jersey location for such a facility was recommended. Doyle's resolution points to the state's unique qualifications as the home of several well-known academic institutions and its status regarding onshore and offshore nuclear electrical generating technologies. Manystates and localities -- including New Jersey -- are vying for various federal energy research facilities because of the jobs and economic benefits such entities create, and this resolution -still pending in the Assembly -- might give further credence to the state's efforts in this regard.

\section{Legislation on Oil and Gas Operations}

A sizeable number of bills have been introduced in the New Jersey legislature dealing with various aspects of oil and gas operations in. or near the state. One bill, introduced by Senator Anne Martindell (Democrat, parts of Hunterdon, Mercer, Middlesex. and Morris Counties), would prohibit drilling for subsoil minerals, gases and oils in the coastal waters of the state, including estuarine waters, wetlands and in the ocean up to three miles from shore, unless an application were first approved by DEP. ${ }^{89}$ Another bill introduced by Assemblyman Hurley (Republican, 
Cape May and Cumberland Counties), would prohibit construction of a deepwater oil port and any related facilities on or adjacent to the New Jersey coast. 90 Senator Buehler has introduced a bill to prohibit construction of offshore oil port apparatus and attendant pipeline and storage facilities. 91 In contrast to these latter two bills, Senator Dodd has introduced a bill calling for construction of a deepwater port off the New Jersey coast. 92 Five public hearings were héld on the 1974 version of Dodd's legislation, and the 1976 version incorporates a number of changes suggested at those sessiuns.

Ihe Sp111 Compensation and Control. Act introduced in Apri.1 1976 by Senator Russo was designed to prohibit discharge of petroleum and other hazardous substances; it also provides for cleanup and removal of any such discharge should one occur accidentally. ${ }^{93}$ This legislation is intended to provide more adequate protection for the resort industry and others threatened by direct or indirect losses resulting from spills of oil and other hazardous substances. It would establish a $\$ 25$ million fund (first proposed for $\$ 50$ million), to be financed by a one cent tax on each barrel of a hazardous substance transferred between major farilities, including refineries and pipelines. The tax would terminate when the fund reached the $\$ 25$ million level, and be reinstituted at up to a four-cent-per-barrel, rate if the fund were depleted by claims resulting from spills.

Governor Byrne and DEP Commissioner Bardin strongly supported this 1egislation, which was co-sponsored by a number of cuastal area senators (among others). The law diffcru from a $\$$, ?no million fereral oil spill fund proposed by the Ford Administration in that the state law would allow compensation for lost anticipated revenues such as hotel rents. 
At a public hearing in June, 1976, oil industry spokesmen and representatives of the New Jersey Chamber of Commerce testified against the bill, saying the federal proposal would preempt state law. Bardin said that preemption was put into the federal proposal at the "instigation of big oil," but noted that Congress has historically given states the right to act on their own to control spills and compensate for them. Bardin said the federal legislation would give oil companies a "free ride" on indirect damages, not requiring any such payments. A spokesman for the Environmental Policy Center (EPC) in Washington, D.C. testified that the proposed New Jersey 1aw would be the strongest in the nation and would have its greatest effect on discouraging spills, since most are caused by carelessness. The EPC spokesman added that the legislation, in providing for unlimited liability by the spiller, also would encourage quick cleanups. Industry spokemsen stated they could not obtain insurance for unlimited liability, a statement supported by insurance company spokemen. Bardin countered by noting that the "economic exposure of New Jersey is greater than that of any other state to the danger of oil spills." He added that the state wants to keep its largest industry, petrochemicals, but not at the expense of wiping out its second largest industry, tourism. 94

This legislation has been considered by the Byrne Administration and others as an urgent measure for the state to enact prior to any acutal OCS oil and gas activity off New Jersey's coast, particularly in view of the Federal leases granted to the oil companies in bids on August 17, 1976. The bill was passed by the legislature. in 1ate 1976, and signed into law by the Governor on January 6, 1977 to become effective in 90 days. As finally passed, the legislation places no limit on compensation to victims 
but would put a $\$ 50$ million limit on claims the fund could pass on to the guilty discharger unless gross negligence or willful intent could be proven. Lobbyists for the oil industry won some concessions, including the size of the fund halved from the original $\$ 50$ million size. The industry also won a provision under which the fund's base would be reduced to $\$ 18$ million if claims in the first three years are less than $\$ 5$ million.

A proposed supplement to the New Jersey Water Quality Improvement Act of 1971 introduced by Senator Dodd also relates to prevention and control of oil.spills. 95 This law directs the DEP, in consultation with affected industries and governmental bodles, to develup contingency plans for ofl cleanup. It requires registration of oil-handling facilities and oil containment and removal equipment as a means of demonstrating to DEP the capability to prevent oil spills and to promptly remove any oil which may be discharged.

A resolution introduced by Assemblyman Foran would memorialize Congress to provide adequate compensation out of federal revenues from offshore exploration and development leases to those states required to incur additional costs for the purpose of dealing with the environmental, social and economic consequences of active exploration for and development of energy source deposits in ocean areas adjacent to their shores. ${ }^{96}$ (A Coastal Energy Impact Fund was devised by Congress in mid-1976 in its amendments to the federal Coastal Zone Management Act of 1972).

One bill introduced by Assemblyman Gewertz (Democrat, parts of Burlington, Camden and Gloucester Counties) would exclude large oi, refineries from participating in state programs to help industries finance the cost of pollution control equipment. 97 Its statement of purpose notes: "Recent 
reports of greatly increased profits and earnings indicate clearly that such persons or firms are well able to finance the acquisition and construction of their own pollution control facilities...."

In May, 1974, a public hearing was held on another bill introduced by Gewertz, legislation knwon as the Petroleum Refinery Regulation Act. 98 Like many of the energy-related bills introduced in 1974 , this was a direct response to the crisis conditions and sharp concerns about fuel supplies. During periods of shortage, the act would empower the PUC to require refiners to produce specified volumes of particular petroleum products. The PUC could also direct sale and distribution of these products to specified customers at reasonable prices, to avoid discrimination or unfair competitive practices. In addition, PUC would collect and publish information concerning supplies, production runs, and storage and distribution procedures of refineries operating within the state. The initial strong support for this legislation is indicated by the fact that the bill has 51 sponsors out of a total Assembly membership of 80 . There are indications, however, that the legislation was never really seriously pursued. This is due, in part, to the considerable powers the bill would grant to the PUC in petroleum regulation, an entirely new area for this body.

Allocation of natural gas supplies is provided for in a bill introduced by Senator Zane (Democrat, Salem and Gloucester Counties), which also requires monthly reports from every gas" company in the state on the adequacy of quantities on hand to meet anticipated demand. ${ }^{99}$ Any company whose supply is not expected to meet demand may petition the PUC for an allocation from a company with excess supply. After a hearing on the 
request, the PUC would render its decision within 30 days. A similar bill was vetoed by Governor Byrne in 1975, primarily because the powers granted in this legislation already exist in the PUC. Although these powers have not often been exercised, the fact that they exist was sufficient in 1974 to persuade some southern New Jersey gas suppliers to cooperate during shortages. 100

Gas pipeline owners would have to assume liability in case of injury to any individual or damage to property under the provisions of a bill introduced by Senator Fay (Democrat, part of Midrlesex County). ${ }^{101}$ Another bill, sponsored by Assemblyman Weidel (Republican, parts of Hunterdon, Mercer, Middlesex and Morris Counties), also deals with the potential dangers from gas pipelines. ${ }^{102}$ This bill would establish a Division of Pipeline Safety. in the Department of Labor and Industry. Both bills are a response to concern over gas pipeline explosions and other accidents. The statement of purpose in Weidel's bill refers to federal funds in the amount of $\$ 55,000$ which would be available to New Jersey if it enforced gas safety standards. The bill also chastises the state when it notes that: "According to the federal Office of Pipeline Safety, New Jersey would be the last state to elect participation in their program."

\section{Energy Conservation}

Several bills dealing with energy conservation also have been considered in the New Jersey legislature. The bill to allow motorists to turn right at red lights was enacted in the legislature in June 1976 and was signed by the Governor on July 6, becoming effective on January 3, 1977.103 It is estimated that this step will save New Jersey motorists annually some 5 million gallons of gasoline and $\$ 2.5$ million. Aside from conservation considerations, the incentive to pass this legislation came from the federal 
Energy Policy and Conservation Act of 1975, which provides states with $\$ 150$ million in energy conservation grants. However, these funds are available only to those states that provide energy conservation measures such as "right turn at red," car pooling, and thermal efficiency standards. For New Jersey, this could mean as much as $\$ 4$ million in federal aid. 104

The New Jersey Industrial Pollution Control Financing Law would be amended by a bill to provide for financing of energy conservation projects undertaken by individuals in their private dwellings, as well as by business, commercial and industrial establishments. 105 Another bill would provide an incentive for use of solar energy, by exempting solar heating and cooling systems from the annual assessed valuation of property and by exempting the purchase, lease or rental of solar energy devices from the state sales tax. ${ }^{106}$ Other bills would exempt from the state sales tax a11 materials used for conservation of heat within a building, and exempt from taxation any improvements made to any building for the primary purpose of insulating and conserving energy. 107

Utility Rates and the Public Utility Commission

Utility rates have increased enormously in New Jersey since 1974, producing the expected political reaction. As a result, a number of bills have been introduced in the legislature to attempt to cope with this issue. Under a bill introduced in April, 1976, the PUC would be required to designate a "lifeline" quantity of gas and electricity necessary to supply the minimum energy needs of the average residential user for space and water heating, lighting, cooking and food refrigeration. ${ }^{108}$ The PUC would require each utility to charge a "lifeline rate" for the established minimum amount of gas and electricity. The lifeline rate could not exceed the lowest rate per kilowatt hour or per therm at which electricity or gas is sold to any other customer of the utility. 
At an August 12, 1976 public hearing before the Assembly's Transportation and Communications Committee, several hundred senior citizens jammed the Assembly chamber to urge enactment of this legislation. PUC Commissioner Richard McGlynn urged the committee not to recommend passage of the bill, and said that adoption of any new rate structure should be left up to the PUC which is conducting its own study of the lifeline concept. Governor Byme, a former PUC President, differed with McGlynn. He told a group of the senior citizens that he believed establishment of new rate policy should be left up to the legislature, and that he had felt the camc way when he headed the Commission. 109

In activities outside the committee hearing, citizens urging passage of lifeline rates legislation pointed out that residential users are charged 6 cents per kilowatt hour for electricity while industry paye only 1.3 cents and commercial accounts pay only 3 cents. Other states, including Maine and California, have adopted some form of lifeline rate measure. ${ }^{110}$ The committee held a second of two public hearings on this legislation later in August. ${ }^{111}$ In late August, however, the PUC rejected Iifeline rates for customers of Jersey Central Power and Light Co., apparently because the two Commissioners could not agree. Commission President Joel Jacobson said he favored the proposal; McGlynn did not.*

In his 1977 State of the State address, Governor Byrne proposed that the state use part of its utility tax revenue from the gross receipts tax to pay for lifeline rates, designed to benefit those with fixed low incomes. Recent increases in rates which utilities arc pormitted to charge because of higher fuel costs, high capital investments, and other inf1ationary

\footnotetext{
"Since the third statutory Commissioner's position remained unfilled for many months, tie votes could not be broken. This was rectified in September 1976 with the appointment to the PUC of state Assembly Majority Leader George H. Barbour (Democrat, Burlington County).
} 
factors have resulted in substantial revenue increases from this 7.5 percent gross receipts tax. ${ }^{112}$ These revenues have risen from $\$ 114$ miliion in 1973 to approximately $\$ 175$ million in $1976 .^{113}$ The Governor suggested that the amount of the gross receipts tax now paid to municipalities. be frozen at the 1976 level, with any future increases used to pay for lifeline rates. 114

Legislation introduced by Senator Merlino on January 11, 1977, the same date as the Governor's speech, proposed that the gross receipts tax be frozen at the 1973 level, with all revenues in excess of that amount funneled into an Energy Relief Fund. The bill provides that the first $250 \mathrm{kw}$ of electricity and the first 110 therms of natural gas used per month would be charged at the lower lifeline rate. Use in excess of these minimum amounts would be billed at regular rates. ${ }^{115}$ The PUC has estimated that the average New Jersey family uses about twice these stipulated amounts. If frozen at the 1973 level, it is estimated that these revenues, most of which currently accrue to about two dozen municipalities, could generate $\$ 18$ million in 1977 and $\$ 45$ million in 1978 for the Energy Relief Fund. 116 Municipalities which currently enjoy the benefits of utility revenues are certain to resist any attempt in the legislature to diminish this source of funds. This includes Senator Merlino's own constituents in Hamilton Township, which in 1975 received nearly $\$ 6$ million in gross receipts taxes. 117

A bill in the Senate also introduced by Merlino would provide for an interlude of at least 12 months between rate hearings concerning the same public utility. Similarly, an Assembly bill would impose a six-month moratorium on any rate increases applied for by any public utility. ${ }^{118}$

Another proposed bill deals with the controversial fuel adjustment clause, whereby a utility can pass on to its consumers increases in the 
costs of its raw materials (fuel, for example). Under the provisions of this bill, introduced by Assemblyman Gewertz, before passing on these costs a utility would be required to certify to the Board of Public Utilities Commissioners that it was obtaining such raw materials at the most economical price. 119 The Board would be required to verify this fact before allowing the rate increase.

A resolution introduced by Assemblyman Froude deals with peak-load pricing, now being used in several states but not yet in New Jersey. 120 An Electric Rate Design Study Commission would be established to investigate the feasibility of implementing peak load or time differential pricing for electricity. By establishing higher rates during periods when demand is high, this is an attempt to make more efficient use of existing generating facilities and thereby lessen the need for construction of new facilities.

Preferential rates for large consumers of electricity would be ended under the provisions of a bill introduced by Senator Ammond. ${ }^{121}$ This bill would require electric utilities to adopt a graduated rate structure providing for higher unit costs for the purchase of greater quantities of electricity. A resolution by Senator Russo would create a commission to carry out an overall study to determine the basis of present and proposed utility electricity rates. 122

Advertising and promotional campaigns of the public utilities have been questioned by some people, and a bill introduced by Senator Menza deals with this issue. ${ }^{123}$ These costs currently are reflected in the rates charged by the utilities and are, therefore, borne by the consumer. This bill would prohibit passing advertising and promotional costs on to 
the consumer, charging them instead to the stockholders and investors.

Finally, a bill introduced by Senator Zane would authorize the PUC to regulate and control radioactive materials and wastes. ${ }^{124}$ This function would bring the PUC into a potential conflict with the responsibilities of the U.S. Nuclear Regulatory Commission, which acts under the provisions of the federal Atomic Energy Act of 1954, as amended.

\section{Legislative Hearings Related to Energy}

A number of public hearings have been held by various legislative committees as part of the process of attempting to formulate energy legislation. These hearings have offered an opportunity for public testimony by various experts and interested parties, and have created a voluminous record on which subsequent legislative actions can be based.

In spite of the number of legislative public hearings and recommendations on energy policy, however, very little if any of this has actually been translated into legislation. There was a hiatus of almost is months when no legislative public hearings at all were held on energy issues. * This long gap offers further testimony to the fact that, after the initial flurry of activity following the OPEC oil embargo and resultant gasoline shortage in the winter of 1973-74, other matters (notably tax reform) took precedence in the New Jersey legislature, to the detriment of energy planning and policy formulation.

Three early hearings were held by the Senate's Ad Hoc Committee on Energy and the Environment in 1973, primarily dealing with the issue of a

\footnotetext{
* This period commenced on November 8,1974 , at which time the Assembly Transportation and Communications Committee conducted a public hearing on A-608, the "Energy Facilities Planning Act of 1974", and terminated on March 10, 1976, at which time the Senate Energy and Environment Committee conducted a public hearing on nuclear energy. Within this 18-month hiatus, numerous open committee sessions were held at which energy and energy-related legislation was discussed. Members of the public, and particularly environmental lobbyists (e.g., Sierra Club, League for Conservation Legislation, etc.), regularly appear and participate at such open committee meetings.125
} 
proposed deepwater port; other issues related to energy development in general were also raised at these sessions. ${ }^{126}$ Based on this testimony and

subsequent committee deliberations, the group presented eight specific

recommendations to the Senate in an April 1973 report:

(1) Enactment of Senate Bill No. 2075, establishing a long-range energy study commission to review: (a) federal and state energy policies; (b) long-range supply and demand prospects for all types of fuel and electricity; (c) benefits and risks of offshore drilling for oil and gas; (d) strategies for conservation of energy and reduction in energy demand; (e) the outlook for new methods of energy production; ( $f$ ) environmental, economic and social implications of a deepwater port off New Jersey; and ( $g$ ) site planning procedures for location of energy-related facilities;

(2) Early activation of the Governor's State Planning Council, so Llial develupment of a state energy policy can be consistent with. the state's overall growth and land-use policies;

(3) Adoption of a poliry that this state not permit the operation of any nuclear power supply facility except those now operating or under construction until a thorough, safe and permanent waste disposal method has been developed and is in operation.*

(4) Establishment of a state energy planning agency to regulate the planning, site selection, construction and operation of bulk power supply facilities, including resolution of all environmental, economic and social issues in a timely and integrated manner. The Committee recommended that the long-range study comission consider the dippropriate structure for such an agency;

(5) Enforcement of a moratorium on construction of any delepwater port off the Atlantic or Delaware coasts of New Jersey untj]. July 1, 1975. During this time a thorough scientific assessment of the environmental, economic and social implications of a port should be undertaken by the long-range study commission;

(6) Enactment of legislation establishing in advance the lines of authority for containment and clean-up of an oil spill and a mecharism for imposing fines and assessing and collecting damages for any economic or ecological loss attributed to any spill. Such legislation would be a condition prior to any port development;

(7) Enactment of legislation providing for stringent regulation by the Department of Environmental Protection of the planning, site selection, construction and operation of any facilities to be used in the transportation, storage, refining or processing of any petroleum products, with particular regard to the protection of the coastal areas of the state. Such legislation would also be a condition prior to any port development; and

*This concept was incorporated in CAFRA's Section 11, as a result of the committee's recommendations, but has not been adopted on a statewide basis. 
(8) Direction to the long-range study commission to give immediate priority to development of a comprehensive program of energy conservation, including an analysis of the feasibility and socio-economic ramifications of various proposals for reducing energy demand.127

In its report to the Senate, the Committee strongly urged passage of legislation to enact these various proposals with respect to energy.* Despite this strong Committee statement, only the Energy Commission concept became law, and even this agency has remained relatively moribund. The group's nuclear waste recommendation was adopted, but only for the CAFRA coastal area. The Senate Ad Hoc Committee, by then established by statute as the New Jersey Energy Crisis Study Commission (see above), held a hearing in February 1974 in response to gasoline shortages and general energy problems prevalent at that time. ${ }^{128}$

The Senate Committee on Energy, Agriculture and Environment held a series of public hearings in February, March and April 1974, dealing primarily with the deepwater port issue. ${ }^{129}$ One bill, sponsored by Senator Dodd, would have created such a deepwater port; another bill, snonsored by Senator Buehler, sought to prevent such a facility. Both bills were referred to the Senate committee; neither passed.

Formal Assembly Committee hearings on energy took place in May 1974, before the Transportation and Communications Committee. Testimony dealt with two bills pending in the Assembly. One provided for regulation by PUC of petroleum refinery operations and of the sale and distribution of petroleum products refined and distributed in New Jersey; the other would have extended the PUC's jurisdiction to cover hydrocarbon fuels. 130

\footnotetext{
'Senator Dodd, one of the Committee members, dissented from the group's report, urging construction of a deepwater oil port and a generally permissive attitude toward all forms of energy facility development, including nuclear energy. 131
} 
In September 1974, this same Assembly committee held a public hearing in Newark on the issue of utility rate regulation. Testimony was taken on five specific items of pending legislation. ${ }^{132}$ Not long thereafter, the long gap in public hearings began.

The Senate Energy and Environment Committee (Agriculture was removed from the Committee's jurisdiction) ended this gap by holding public hearings on March 10 and April 3, 1976, at Ocean County College in Toms River. These hearings, chaired by Senator Russo, were devoted almost entirely to testimony and committee questions on nuclear energy in New Jersey. The committee heard from, among others: DEP Commissioner David Bardin, Public Advocate Stanley van Ness, Jersey Central Power and Light Company President Shepard Bartnoff, PUC Chairman Joel Jacobson, and representatives of the Pub1ic Service Electric and Gas Company and the New Jersey Public Interest Research Group.

\section{Conclusions}

The state's income tax controversy was more or less settled on July 8, 1976, after a 10-year legislative battle and a 2-year budgetary crisis heightened by the New Jersey Supreme Court's order. which closed all public schools on July 1, 1976. No other important legislation was enacted prior to the legislature's adjournment until september, although a strong oil spill bill was passed in January 1977. Since 1977 is an election year when both the governorship and all 120 seats in the legislature are at stake, it is problematical whether substantive energy legislation will be enacted during this period, given the superheated atmosphere which of ten exists at such times.

\footnotetext{
* Necessary companion legislation to the tax bill was not passed until August 17, 1976 .
} 
Thus, unless some crisis occurs (or strong leadership emerges) to jolt legislative activity, it is probable that New Jersey, one of the most industrialized and energy-intensive states in the nation, may not in the near future be prepared to deal adequately with its many complex energy planning issues. This is particularly serious since the state is an energy "hot-spot" with various precedent-seting proposals at its doorstep -- e.g., the floating nuclear plants, and Outer Continental Shelf drilling in the Atlantic Ocean off its coast. In addition, New Jersey pays the highest cost in the nation for natural gas, ${ }^{133}$ and is the scene of several nuclear power plant proposals. As a further indication of New Jersey's high energy profile, it is one of the four coastal states (Texas, Louisiana and California are the others) which contain $60 \%$ of total U.S. petroleum refining capacity. 134

That this inaction does not stem from lack of legislative interest is evident in the number and variety of bills which have been introduced in the legislature in the 1974-76 period. Rather, it emanates from the political fractiousness which continues to exist in the state in intra-party disputes (currently both the Governorship and the legislature are held by the same political party); lack of a legislative mandate; absence of a clear, powerful constituency in support of innovative new energy legislation; and the lack of effective leadership. Such leadership and interest, which set priorities and carry the weight to push programs through the maze of rival interests, certainly have not been apparent in New Jersey with respect to energy. An illustration of legislative paralysis is reflected in the state's inability to form an Energy Office with adequate 
legal status, since the law creating this office lapsed in June, 1975 and no new legislation has achieved passage. Differences of opinion as to the jurisdictional location of the Energy office and preoccupation with the tax issue have stalled action even on this basic structural issue. Thus, the state is left with no legally-constituted comprehensive energy planning agency at the same time that enormous energy pressures are building. The 1976 session of the legislature was characterized, in fact, as one of the least productive overall in many years. 135

The energy crisis which hit public consciousness hard in the winter of 1973-74 colncided with New Tersey's rnntinuing srifif nver finances and tax reform. The record indicates that the years 1974-76 saw no definitive energy planning steps taken, despite the fact that this is a state in which energy remains an issue of critical importance. 
1. One third of New Jersey's work force is dependent on natural gas, according to Charles Richman, Executive Director, New Jersey State Energy Office; personal communication with Grace Singer, Princeton University Center for Environmental Studies Researcher, August 2, 1976.

2. David More11 and Martin Wohlforth, Issues in Energy Facility Siting: A Case Study of a New Jersey Oil Refinery Decision (Princeton, NJ: Princeton University, Center for Environmental Studies), report forthcoming, 1977, Chapter III.

3. Governor Brendan T. Byrne's State of the State message, January 11, 1977.

4. New Jersey Legislative Index, 1976, p. 4.

5. Ibid., p. 15 .

6. P. L. 1973, Chapter 184, approved 6/20/73, amended 2/4/74 (P.L. 1974, c. 3).

7. Ibid. (P.L. 1974, P. 1).

8. There were apparently two reasons for not naming the Commissioner of the Department of Environmental Protection (DEP) to the Energy Commission. First, nominations were made during the interregnum between the tenure of Commissioner Richard Sullivan and present-Commissioner David J. Bardin; and second, there was already a controversy over naming the DEP Commissioner to the Coastal Area Facility Review Act (CAFRA) Board (where some claim he sits in judgment over his own decisions).

Interview by Singer, with J. Mark Reifer, Supervising Research Associate in the N.J. Law Revision and Legislative Services, Division of Legislative Information and Research, August 12, 1976. Reifer is the supervisor of a staff that serves 11 legislative committees, including all those which recelive energy legislation.

9. P.L. 1973, P. 2 .

10. Ibid.

11. Interview by Singer with Reifer, supra note 8, February 3, 1976.

12. The overa11 energy data question is explored, and a new approach recommended, in: Margaret Fulton Fels, Exploring An Energy Data Base for New Jersey (Princeton: Princeton University, Center for Environmental, Studies, Report 非30, May 1976).

13. Interview by Singer with Richman, supra note 1. 
14. Letter from Reifer (supra note 8) to David Morel1, Princeton University, Center for Environmental Studies, July 20, 1976. Reifer further notes that: "None of the 15 professional researchers under my supervision has ever, to my certain knowledge, experienced the slightest difficulty in obtaining any information required in the preparation or review of legislation from any private corporation involved in producing, distributing, converting, or, even, using energy in any form. There are, of course, "Trade Secrets" for which we would not ask, and which we would not expect to be given in the absence of a state law protecting their confidentiality. There was such a state law in the form of the emergency energy fair practices act, which, as your study accurately notes, expired on June 30,1975 . In the absence of such a state law today the corporations of the New Jersey are quite justified in withholding all information which would in any way prejudice their competitive position."

15. Ibid.

16. Governor's Executive Order No. 9, Uctober 2, 1974.

17. Report of the Sub-Committee on Urgent Energy Problems (Trenton: Energy Crisis study Commission, October 10, 1973), pp. 1-2, 4-5.

18. Interview by Singer with William E. Schluter, former State Senator, May 3, 1976.

19. Ibid.; analyses of the Tocks Island Dam controversy are presented in: Laurence H. Tribe et. al., eds., When Values Conflict (Cambridge, Mass.: Ballinger, 1976) and H. A. Feiveson, et. al., eds., Boundaries of Analysis (Cambridge, Mass.: Ballinger, 1976).

20. New Jersey did not, however, join with New York State, Nassau and Suffolk Counties (in New York), five Long Island towns, and the Natural Resources Defense Council, Inc. in the suit which resulted in a temporary injunction granted on August 13, 1976 by a federal judgc in Ncw York. Judge Jack Wcinstcin, in hic temporary injunction, questioned the effect of transporting offshorc oil by tanker if states blocked pipelines on their coasts and contended that there was a deficiency in the environmental impact statement that the Interior Department had prepared for the proposed leasing of 876,750 acres in the Atlantic Ocean 60 miles south of Long Island and 47 to 90 miles east of New Jersey. According to Judge Weinstein, the Interior Department erred in assuming that oil and natural gas on the Outer Continental Shelf would be transported through pipelines to the east coast. (New York Times, August 17, 1976, p. 1.).

In a poot hearing memorandum, the Natural Rocourcec Dofenee Council contended that 240 miles of pipelines that gas and oil companies would like to lay in New Jersey would cause "severe disruption." The Council, in its memorandum, stated that New Jersey was the "point of primary onshore impact" and that the onshore impacts of pipelines, refineries, gas processing plants, petrochemical plants and other facilities would be "the most severe" of the drilling program, but the Interior Department's environmental assessments had "distilled" these impacts "down to pablum." (Donald Janson, New York Times, August 13, 1976, p. B3). 
James Mitchell, a Rutgers University professor of environmental resources, stated at the hearing that the Interior Department's estimate of the acreage needed for pipeline and other onshore facilities was far too low and its study gave inadequate weight to the impact of development on the Pine Barrens. An MIT expert, Jerome Millgram, stated that an oil spill could put as much as 500,000 gallons of oil on New Jersey and Long Island beaches. (Trenton Times, August 15, 1976, editorial, p. C2). Governor Byrne's counse1, Alan E. Handler, stated that New Jersey "supported the New York effort", kept in close touch with New York's attorneys arguing the case, and,"felt the relief sought by New York would serve New Jersey's interest."

Although the state of New Jersey did not join in the suit, Thomas A. Thomas and Elwood Jarmer, officials of the Planning Boards of Ocean and Cape May Counties, respectively, testified about their fears of the adverse impact of offshore drilling on their areas. The Interior Department in its post-hearing memorandum stated this "epitomized the parochial interests involved in this attempt to prevent Outer Continental Shelf leasing. These men simply do not want any sort of development or environmental impact that would affect their resort communities", the Interior Department said. It further said national needs for greater domestic oil supplies transcended "parochial" concerns. (Donald Janson, New York Times, op. cit.).

The injunction was lifted on August 16 by the U.S. Court of Appeals, and a dramatic final effort by New York State attorneys to appeal to the U.S. Supreme Court was unsuccessful when, on August 17, the scheduled date of the bidding, Associate Justice Thurgood Marshall decided to allow the bidding. It commenced later on that date, bringing in $\$ 1.14$ billion in bids by more than 60 oil companies for 101 of 154 tracts. The Baltimore Canyon is believed to hold as much as 1.4 billion barrels of oil and up to 9.4 trillion cubic feet of gas, worth an estimated total as high as $\$ 31$ billion. (Terry Kirkpatrick, Associated Press, Trenton Times, August 17, 1976).

The U.S. Court of Appeals in New York, in lifting the injunction, said it would study the environmental issues raised in this case. (Ibid., August 18, 1976).

21. Interview by Singer with Reiffer, op. cit; and interview by Singer with David C. Mattek, Legislative Aide to the Senate Committee on Energy and Environment, February 3, 1976.

22. P.L. 1973, op. cit.

23. S. 670 , became Chapter 46 of P.L. 1976.

24. P.L. 1974, Chapter 2, approved 2/4/74, amended 2/15/74 (P.L. 1974, Chapter 6).

25. Interview with Richman, op. cit.

26. Ibid. 
27. Interview by Singer with Philip Forlenza, attorney and Chief Regulatory Officer, New Jersey Baord of Public Utility Commissioners, August 2,1976 .

28. W. A. Kuncik, "Land Use Politics in New Jersey: The Strategy of Redefinition," Unpublished paper to fulfill graduate course requirement, Woodrow Wilson School, Princeton University, June 1975, p. 23.

29. Lorraine Graves, The Development of the CAFRA Boundary (Trenton: Office of Coastal Zone Management, N.J. Department of Environmental Protection, March 1976), p. 17.

30. Courier Post (Camden), April 17, 1973.

31. Graves, op. cit.

32. Ibid.

33. Ibid, p. 19.

34. Ibid.

35. Ibid., p. 21 .

36. "Coastal Zone Management in New Jersey in 1976", Remarks by New Jersey Commissioner of Environmental Protection David J. Bardin, before the Advisory Committee of the Texas Coastal Zone Management Program, General Land Office, State of Texas, January 13, 1976, Houston, p. 3 .

37. Coastal Area Facility Review Act, P.L. 1973, Chapter 185, Section 11:

38. New York Times, December 15, 1976, p. B-3.

39. Trenton Times, November 18, 1976, p. B-12.

40. Department of Environmental Protection, Opinion 20, CAFRA Application CA \#14-014, September 3, 1975.

41. Ibid.

42. League for Conservation Legislation, Newsletter, Volume 5, No. 4., June/July 1976, pp. 3,4.

43. DF.P npininn 2n, np. rit.

44. New Jersey Senate Ad Hoc Committee on Energy and the Environment, Report to the Senate: Some Recommendations, April 5, 1973, p. 17.

45. Interview by Singer with Edward Lloyd, N.J. Public Interest Research Group, August 12, 1976.

46. Trenton Times, May 17, 1976. 
47. Interview by Singer with Thomas F. Hampton, Supervisor, Office of Wetlands Management, Division of Marine Services, DEP, August 20, 1976.

48. John Echeverria, Riparian Law and Coastal Zone Management in. New Jersey, Staff Discussion Paper, Draft 非 (Trenton: N.J. Department of Environmental Protection, Division of Marine Services, Office of Coastal Zone Management, October 8, 1976), p. 13 .

49. N.J.S.A. 12:5-3. (Department of Environmental Protection, Opinion 20, op. cit., p. 8).

50. Interview by Singer with Edward Linky, Staff Attorney, Division of Marine Services, Office of Coastal Zone Management, DEP, re N.J.S.A. 12:3-7, 10 August 20, 1976.

51, Letter to Singer from Helga Busemann, Division of Marine Services, Office of Coastal Zone Management, DEP, August 13, 1976.

52. Edward Linky, An Inventory of Environmental Law in New Jersey: State Authority (Trenton: DEP, Division of Marine Services, Office of Coastal Zone Management), July 1976).

53. E11a Bone Chatterjee, A Study of New Jersey's Coastal Area Facility Review Act: Development of Legal Theories to Avoid Federal Pre-emption of State Regulation of Atomic Energy (Philadelphia: Temple University School of Law), April 1976, p. 26.

54. Linky, An Inventory..., op. cit.

55. See Chatterjee, op. cit., especially pages 5 (first paragraph), 27 (third para.), 30 (last para.), 35 (first and second para.) and 36.

56. Brookhaven National Laboratory, Regional Energy Studies Program, Preliminary Assessment of a Hypothetical Nuclear Energy Center in New Jersey (Upton, N.Y.: BNL 50465, November 1975), p. 104.

57. Ibid., pp. 104, 106.

58. State of the State message, op. cit.

59. BNL, Preliminary Assessment..., op. cit., pp. 107-108.

60. David Kinsey, New Jersey Coastal Zone Coordinator, Remarks before the April 10, 1976 meeting of the League for Conservation Legislation (LCL Newsletter, Vol. 5, No. 3, May 1976).

61. OCS-Related Onshore Development, a report from Roger M. Schwarz, Deputy Attorney Genera1, N.J. Dept. of Law and Public Safety, to the Cabinet Energy Committee, February 23, 1976, p. 10.

62. Ibid., pp. 9-11.

63. Assembly Concurrent Resolution No. 203, August 5, 1975. 
64. P.L. 1975, C. 217 (October 7, 1975).

65. Background information on New Jersey State Uniform Construction Code, N.J. Department of Community Affairs, November 18, 1975; and interviews by Singer with Mr. Charles Decker, Department of Community Affairs, May 19, 1976 and January 18, 1977. ASHRAE (American Society of Heating, Refrigeration and Air Conditioning Engineers) Advisory Code 9075 is a suggested energy conservation addendum to building codes. As of January, 1977, the effective date of the energy subcode was pushed back to mid-1977 to work out enforcement and other issues.

66. New Jersey has 2-year legislative sessions, and bills introduced in the first year of a legislative session "carry-over" into the second; bills not enacted into $1 \mathrm{aw}$ at the end of the second year of each such legislative session are considered to be "dead", and must be reintroduced in the succeeding session if they are to be considered. Legislation introduced in 1974 was "alive and well and living in Trenton" throughout 1975, but died on the second Tuesday in January, 1976. All energy and energy-related legislation pending today in the New Jersey Legislature was introduced after January 13, 1976, though much (if not most) of it was originally introduced in 1974 or 1975 (and some in 1972 or 1973), at which time each such piece of legislation had a different bill number than that it has at present. (Letter from Reifer, supra note 14).

67. S-1407, introduced on April 26, 1976.

68. Testimony of David J. Bardin, Commissioner of Environmental Protection before the Senate Committee on Energy and Environment, Toms River, March 10, 1976.

69. A-1525, originally introduced in 1972 as A-1673; in 1974 it was reintroduced as $\Lambda-608$. The 1976 veislun of this legislation is pending in the Assembly Energy and Natural Resources Committee.

70. S-80'2 was introduced by Senator Raymond Bateman (Republican, part of Somerset, Hunterdon and Morris Counties). Tt was originnlly Introduced in 1973 as S-2338; in 1974, it was re-introduced as S-466. Following Senate passage, the 1976 version of this bill is pending in the Assembly's Energy and Natural Resources Committee.

71. S-193 was originally introduced in 1975 as S-3352. This bill was reported to the floor of the Senate by the Senate's Energy and Environment Committee on April 29, 1976.

72. See David More11 with Dyche Kinder, Housing Growth in the Vicinlty of Nuclear Power Plants: A Case Study (Princeton, iJJ: Princetnn Iniversity, Center for Énvironmental Studies), report forthcoming, 1977.

73. S-1613, introduced August 12, 1976.

74. Interview with Linky, supra note 50, January $11,1977$.

75. See Brian O'Reilly, "Over The River and Into The Woods", New Jersey Magazine, Vol. 6, No. 7, December 1976, pp. 3-10, 32. 
76. S-1494; other sponsors are Senators Ammond, James Cafiero (Republican, Cape May) and Herbert Buehler (Democrat, Monmouth).

77. Trenton Times, June 6, 1976 .

78. ACR-166.

79. A-2073, sponsored by Assemblymen Stewart, Bassano (Republican, Union County); Foran (Republican, parts of Mercer, Hunterdon, Morris and Middlesex Counties), and Markert, (Republican, Bergen County).

80. S-1013, sponsored by Senators McGahn, Buehler, Martin Greenberg (Democrat, Essex County), and Joseph Merlino (Democrat, Mercer County).

81. S-102.

82. $S-636$.

83. S-495, sponsored by Senator Joseph Maressa (Democrat, parts of Gloucester, Camden and Burlington Counties), was originally introduced in 1975 as S-3280. The 1976 version of this bill is pending in the Senate Energy and Environment Committee.

84. A-1296, sponsored by Assemblyman Richard Van Wagner (Democrat, parts of Monmouth and Middlesex Counties), was originally introduced in the 1974 legislative session as A-2156.

85. S-1381.

86. A-790 of 1976, origina1ly introduced in 1974 as A-1269.

87. ACR-1 of 1976, originally introduced in 1974 as ACR-2.

88. ACR-155 of 1976, originally introduced in 1975 as ACR-3034.

89. S-582 of 1976, originally introduced in 1974 as S-1152.

90. A-350 of 1976, originally introduced in 1973 as A-2003; it was reintroduced in 1974 as $\mathrm{A}-730$.

91. S-22 of 1976, originally introduced in 1974 as S-689.

92. S-1135 of 1976, originally introduced in 1974 as S-200. Its short title is the "Oil Transfer Facility Corporation Act."

93. A bill similar to Senator Russo's S-1409 of 1976 was introduced by Senator Lynch (S-1397). Since both bills raise revenue through the imposition of a tax on oil movements, they are constitutionally required to originate in the General Assembly. Senator Russo's S-1409 is Assemb lyman Newman's A-1903; Senator Lynch's S-1397 is Assemblyman Bornheimer's A-1915. Newman is a Democrat representing parts of Burlington, Monmouth and Ocean Counties; Lynch is a Democrat representing parts of Middlesex and Somerset Counties; Bornheimer is a Democrat representing part of Middlesex County.

44. Trentun Times. June 3, 1976. 
95. S-623 of 1976, originally introduced in 1972 as S-783; in 1974 it was re-introduced as S-196. The 1976 version of this bill is pending in the Senate Energy and Environment Committee.

96. ACR-160 of 1976, originally introduced in 1974 as ACR-218.

97. A-985 of 1976, originally introduced in 1974 as A-1468.

98. A-983 of 1976, originally introduced in 1974 as A-1208.

99. S-680 of 1976, originally introduced in the Assembly in 1974 as A-1381.

10). Interview by Singer with Charles Richman, op. cit., January $21,1977$.

101. S-124 of 1976, originally introduced in 1973 as A-2436; in 1974 it was re-introduced as A-143.

172. A-819 of 1976 , urlg1naliy introduced in 1971 as A-2448; in 1972 it was re-introduced as A-242; in 1974 it was re-introduced again as A-295.

103. P.L. 1976, c. 46 (C. 39: 4-115); this bill was introduced by Senator Menza (Democrat, part of Union County) as S-670.

104. Trenton Times, June 11, 1976.

105. A-1248 of 1976, originally introduced in 1975 as A-3179.

106. A-1801 of 1976, introduced by Assemblywoman Burgio (Republican, parts of Essex, Morris and Passaic Counties).

107. A-735 and A-736, respectively, of 1976 were both introduced by Assemblyman Karcher (Democrat, part of Middlesex County). The former was originally introduced in 1974 as A-1274," the latter as A-1275.

103. A-1830; S-1447.

109. New York Times, August 13, 1976.

110. People and Energy, Vol. II, No. 7, July 1976, p. 2.

111. Trenton Times, August 13, 1976.

112. See Peter Meier and David Morel1, Issues In Clustered Nuclear Siting (Upton, NY: Bronkhaven National Laburatory, BNL 50561, September 1976), pp. 255-275.

113. New York Times, January 14, 1977.

114. Governor Byrne's State of the State address, op. cit.

115. S-3015.

116. I'renton Times, January 15, 1977.

117. Department of Community Affairs, Thirty-Eighth Annual Report of the Division of Local Government Services: 1975 (Trenton: DCA, November 1976), p. 268. 
118. S-344 of 1976 was originally introduced in 1974 as S-992; A-861 was originally introduced by Assemblyman Shuck (Democrat, part of Camden County) in 1974 as $\mathrm{A}-2040$.

119. A-991 of 1976, originally introduced in 1974 as A-1855.

120. AJR-7 of 1976, originally introduced in 1974 as AJR-33.

121. S-234 of 1976, originally introduced in 1974 as S-977.

122. SCR-20 of 1976, originally introduced in 1974 as SCR-145.

123. S-315 of 1976, originally introduced in 1974 as S-1115.

124. S-204 of 1976, originally introduced in 1971 as S-2079; in 1972 it was re-introduced as S-607; in 1974 it was re-introduced again as S-871.

125. Interview by Singer with Reifer, op. cit., June 16, 1976; and letter from Reifer to Morell, op. cit.

126. Minutes of the Publi.c Hearing before the Senate Ad Hoc Committee on Energy and the Environment exploring question of Deepwater Port (relative to proposed legislation) and energy development in general. Volume 1, January 23, 1973; Volume II, February 6, 1973; and Volume III. February 20, 1973.

127. Report to the Senate: Some Recommendations, op. cit., pp. 6-7.

128. Public Hearing before the New Jersey Energy Crisis Study Commission, February 5, 1974.

129. Public Hearings before the Senate Committee on Energy, Agriculture and Environment on Senate Bil1s 200 and 689, February 25, 1974; March 4, 1974; April 3, 1974; April 6, 1974; April 10, 1974.

130. Public Hearing before the Assembly Transportation and Communications Committee on Assembly No. 1208 and Assembly No. 1256, May 30, 1974.

'131. New Jersey Senate, Dissenting Statement by Senator Frank J. Dodd, April 5, 1973.

132. Public Hearing before the Assembly Transportation and Communications Committee, September 27, 1974. The five items of legislation which constituted the subject of th1s hearing were: (1) A-1527, sponsored by Assemblyman Herbert Klein, which would prohibit public utilities from giving preferred rates to high-volume users; (2) A-1855, sponsored by Assemblyman Kenneth Gewertz, which would require utilities to certify that any proposed use of raw materials adjustment 
clauses represented the most economical price; (3) A-2105, sponsored by Assemblywoman Betty Wilson, which would require utilities to institute low-cost "lifeline" rates for residential consumers;

(4) ACR 203, sponsored by Assemblywoman Gertrude Berman, which would create a special commission to review the PUC's powers and responsibilities; and (5) SCR 145, sponsored by Senator John Russo, which would create a commission to study present and proposed electricity rates of public utilities.

133. Interview by Singer with Charles Richman, op. cit., June 2, 1976.

134. Energy Facility Siting in Coastal Areas, Report to the U.S. Committee on Commerce and the National Ocean Study, December 1975, p. 2.

135. New York Times, June 14, 1976. 


\section{MARYLAND: INITIATIVES IN POWER PLANT SITING}

Maryland's legislature evidenced strong innovation in preparing and enacting one of the nation's most comprehensive power plant siting laws in the early 1970's, primarily in response to a controversy over the Calvert Cliffs Nuclear Generating Station on Chesapeake Bay. This law includes such important features as long-range site planning, prior state acquisition of an inventory of acceptable s̀ites, and a financing mechanism linked to electricity production in the state. However, the law covers only power plants, and does not affect siting of other energy facilities. Moreover, provisions for participation in this siting process by local governments and the public at large are very weak, with the state having near-total pre-emptive authority over local decisions.

Like most of the states in the Northeast, the legislature and the rest of state government in Maryland haveshown far less innovative capacity in dealing with other public policies in the energy arena. The Power Plant Siting Act of 1971 continues to stand out as the major exception.

\section{Legislature Structure}

Maryland's 90-day legislative session runs from mid-January to mid-April each year. Neither house of the legislature, termed the General Assembly, has a committee devoted solely to energy issues. In the 141-member House of Delegates, the Environmental Matters Committee receives all energy legislation. This committee is chaired by Delegate John S. Arnick (Democrat, Baltimore County), who is also Majority leader; it has a large membership, 23 legislators. In addition, energy issues involving appropriations are sent to the House 
Appropriations or Ways and Means Committees. In the 47-member Senate, there is not even an environmental committee, and the Economic Affairs Committee receives energy legislation. This committee is chaired by Senator Harry. J. McGuirk (Democrat, Baltimore City) and has a total membership of 9 Senators. If appropriations are involved, energy policy proposals will also be deliberated by the Senate's Finance Committee. ${ }^{1}$

The legislature does not have its own energy research staff, but uses the Maryland Scientific Advisory Council, a private research group, ${ }^{2}$ Several proposals have been made to create a Div1slou of Energy for the General Assembly, to be composed of legislators and staff. In 1975, however, this concept was rejected in the General Assembly. ${ }^{3}$

Because the legislative session is relatively short, committees meet three and sometimes even five days a week, Lhus giving continuity to their deliberations. This contrasts with New Jersey, for example, which has protracted legislative sessions (sometimes 9 months) in which committees may deliberate only once or twice (or not at all) during the course of a week, sometimes due to lack of a quorum. Maryland's large House Environmental Matters Committee does nót seem lu suffer thio problem as frèuently.

\section{Energy Facility Siting Legislation:} The Power Plant Siting Act of 1971

Among those who have siudled the subjcct of energy facility siting at both state and national levels, Maryland's Power Plant Siting Act (PPS is considered the most innovative and comprehensive contribution to state or federal law dealing with long-range energy and land use planning. ${ }^{4}$ Background

The state's enactment of the PPSA in 1971 grew out of concern over the future use of Chesapeake Bay and its tributaries, and out of a serious 
controversy involving approval of the state's first (and only) operating

nuclear power facility, the Calvert Cliffs Nuclear Generating Station

located directly on Chesapeake Bay. This was a prominent issue during the 1967-71 period, resulting in formation of a Governor's Task Force on Nuclear Power Plants in July 1969. This group was officially charged to answer the question:

"Do the special characteristics of nuclear power plants constitute a sufficient threat to the health, safety, or economy of Maryland to justify further action on the part of the state?" 5

In December 1969, the Task Force issued its report, entitled Nuclear

Power Plants in Maryland. The group summarized the Calvert Cliffs issue

as follows:

"The sequence of approvals and permit issuance for the Calvert Cliffs Nuclear Power Plant was felt by a large sector of the public to be improper; this sequence should not be permitted to recur.

Excavation at the Calvert Cliffs site began before the first public hearing by the AEC, and construction permits were issued although no approval has yet been obtained from the Department of Water Resources for permission to use Chesapeake Bay water to cool the condensers. As a result a public distrust has developed, with accompanying accusations that the regulatory agencies will be forced to approve normally unacceptable designs. During the 1968 session of the Maryland General Assembly, laws were amended so that construction of power plants and transmission lines cannot be started before permits are obtained from the Public Service Commission. At the same session, the water resources law was amended so that water use permits must not be obtained before construction begins." 6

Recommendations made by the Task Force included:

1. Immediate steps should be taken to define and/or establish an organizational authority for decisions on siting of nuclear power plants;

2. A state environmentàl monitoring program for Chesapeake Bay should be established, beginning with monitoring of effluents from the Calvert Cliffs plant;

3. Immediate steps should be taken to strengthen and coordinate the existing Environmental Research Program. 7

As is often the case, a crisis condition created the fertile atmosphere 
for far-reaching legislation. In this case, the Calvert Cliffs issue became a major springboard for enactment of the comprehensive Maryland PPSA.

In 1970, then-Delegate William Goodman (Democrat, Prince Georges County) introduced power plant siting legislation, a much simpler version than the statute which eventually became law. After Goodman's measure died at the close of the 1970 session, he worked with various legislative leaders, the Governor's office, and the Department of Natural Resources (DNR). These groups considered three alternative courses for legislative action:

1. Push for a comprehensive law (the currenl statute);

2. Enact a law dealing solely with research, and containing no formalized means to inject research into the decision-making process (this option wis llee one originally defeated in the legislature in 1970); or

3. Provide for research and site evaluation as the basis for nonbinding recommendations from UNR to the Publlc Service Commigsion (PSC), which would then authorize (or deny) construction of proposed energy facilities.

Goodman returned to the legislature in 1971 as a Senator. He opted for the comprehensive approach, which received the endorsement of Governor Marvin Mandel as part of his 1971 legislative program. ${ }^{8}$ Senator Goodman was the sole sponsor of this bill, which passed overwhelmingly on July 1, 1971.9 There was only one opposing vote in the Senate and 15 opposing votis in the House of Delegates. ${ }^{10}$

Principal Features of the Power Plant Siting Act

The two most significant dffferences betwecn Maryland's siting law and that of other states are: (1) its provision for advance state acquisition of

\footnotetext{
* Senator Goodman was also the author of the state's Wetlands Law and was the first legislator to support a plan for Transfer of Development Rights to control urban sprawl. 11 There are some who saw Goodman as a maverick who was more progressive than his constituents. This may have contributed to his defeat in his 1974 primary election bid for another term in the Senate.
} 
sites for new energy facilities; and (2) the establishment of an Environmental Trust Fund based on a surcharge on electricity generation. ${ }^{12}$

The law is administered primarily by the Department of Natural Resources (DNR), which classifies each site proposed in each utility's 10-year plan as either suitable or unsuitable. DNR administers the Fund and the power plant environmental research program, and has responsibility for acquiring a state inventory of potential sites. The Public Service Commission (PSC) retains final authority under the act for approving proposed facilities and issuing Certificates of Public Convenience and Necessity, which constitute the formal authorization to construct a power plant. Thus DNR recommends and advises, PSC makes the final decision. Other participants in this process are the Departments of Health and Mental Hygiene, Economic and Community Development, Agriculture and State Planning.

Ten-Year Plan and Site Evaluation. The PSC receives and evaluates the annual plans of the state's public utilities, which include a ten-year forecast of proposed and potential sites. These documents are then sent to the DNR Secretary. Within six months of receipt of a plan, DNR prepares a preliminary statement on each approved site: its environmental impact, irreversible or irretrievable commitment of resources, monitoring for environmental effects, necessary remedial actions, and site alternatives. The DNR Secretary is authorized to classify all proposed sites as to their suitability. A 1972 opinion by Maryland's Attorney-General indicated that if use of any site would result in any violation of federal or state environmental standards, such a site must be declared unsuitable. ${ }^{13}$ If a proposed site is determined to be unsuitable, the PSC must delete it from the 10-year plan unless the utility whose proposed site is affected can 
prove'by "substantial evidence" that the site should be retained. All sites already owned by utilities or slated for purchase in the future are to be included in the inventory of possible and proposed sites, thus initiating their evaluation by the state.

When a site has been classified as potentially acceptable, the DNR Secretary initiates a detailed investigation. A comprehensive environmental statement must be published at least two years prior to commencement of the facility's construction. DNR also publishes a biennial cumulative environmental impact report on all electric power plants operating in Maryland. This report includes all changes expected to occur as additional plants are constructed in accordance with the utility's 10-year plans. On the basis of all this information, DNR also recommends specific state environmental policies and objectives to the Governor.

State Acquisition of Sites. Detailed investigation to determine site suitability must be completed by DNR within two years. At the end of that period, the state must either purchase the site or remove it from further consideration. Sites are paid for from the Environmental Trust Fund administered by DNR. DNR has authority to selece and acquire anl inventory of no less than four nor more than eight sites for future power plants, based. on estimates of need from the Department of State Planning. The reserve must include at least one site suitable for use by each utillty generating more than 1,000 megawatts of power in the state (curcently only two utilitics in the state fall in that category). ${ }^{14}$ Sites may be acquired by contract or condemnation.

Following acquisition, sites are held in a Site Bank and are to be made available to utilities either through purchase at fair market value or under 
99-year leases. Pending use by a utility, these areas may be used for recreation or other approved purposes. A utility may request a state site either when its own proposed site is classified unsuitable and an alternate is required, or when it has need for an additional, generating facility and is unable to acquire a. site through its own efforts. When state-acquired sites are used, they are exempt from any local zoning rules, regulations or ordinances, and may be used for electricity generation without approval by any county or municipal authority or agency. Upon certification by the state, utility-acquired sites are also exempt from local zoning.

PSC Certification of Public Convenience and Necessity. Prior to construction of a facility, a Certificate of Public Convenience and Necessity must be obtained from the PSC. Upon notification that PSC has received an application for construction, DNR must complete any additional studies and investigation of the proposed site. DNR then gives the PUC its recommendation that the certificate be granted, denied, or granted with such conditions as are deemed necessary. The DNR analysis and other data developed under. the program must be available for public inspection, and are presented by DNR at the PSC hearing. Within 15 days following conclusion of the hearing, and based on the evidence presented, the DNR Secretary must presentits final recommendation to the PSC. Within 90 days after the hearing, PSC must grant or deny the certificate, or grant it subject to conditions.

The one-stop PSC certificate procedure includes many state requirements previously subject to separate actions by various agencies, including those dealing with private wetlands, water appropriation and use, and air emissions. Other state agencies act in an advisory capacity to the PSC. The act makes provision for judicial review for any party aggrieved by the PSC's final : 
decisions. Although PSC has final approval authority, the DNR Secretary has explicit standing to seek judicial review relative to the environmental aspects of power plant siting, thus permitting an advocacy role.

The PSC retains jurisdiction over approved facilities. 15 However, according to the evaluation of one state official, the PSC has a small, part-time staff and is not really structured to deal with complex issues in a comprehensive manner. 16

Environmental Trust Fund and Research Program (Fund). The DNR Secretary administers the Fund, which was financed initially by a surcharge on electricity consumed throughout Maryland. The act was amended in 1974 to add electricity generated in Maryland for sale to out-of-state customers. Beginning in January, 1972, the surcharge rate was 0.1 mill per kilowatt hour generated. Each year the surcharge is set at a level necessary to support the siting program, but it cannot exceed 0.3 mills nor may it continue beyond 1985 . The legislation specifically authorized utilities to add the surcharge to customers' bills."

In addition to site acquisition, revenue from the Fund is used for a program of continuing research on power plant siting and related environmental impacts. This research covers biological and ecological baseline studies, evaluation of new power generation technologies designed to minimize environmental effects, determination of potential use of waste energy released at proposed facilities, and analysis of the socio-economic and land use impacts of power plants. By $19 / 6$, such evaluations had cost close to $\$ 1,000,000$ tor an individual site. ${ }^{17}$ Another feature of the law provides for reimbursement of

* The surcharge was set at almost 0.22 mills per kilowatt hour in fiscal year 1976, and may be adjusted in order to provide a 1977 budget of $\$ 7,136,573.18$ This budget level reflects a state staff of 9 professionals and 4 secretaries and a contractual structure involving approximately 150 scientists. 19 From its inception through March 1976, the Power Plant Siting Program had expended $\$ 16,300,000$ of the $\$ 23,517,713$ authorized. 20 
utilities from the Fund for their environmental site evaluations needed to meet local, state and federal requirements. *

Payments to the Fund are based directly on the amount of energy used. Thus those who use the most energy, pay accordingly. This autonomous, substantial, self-financing source of funding for activities related to power plant siting gives Maryland an advantage over other states which use fees to finance the administrative costs of their energy facility siting programs. Activities Under Maryland's Power Plant Siting Program: An Update

To date, only one site has been acquired under the PPSA, the Elms site in south-central Maryland. Other sites have been investigated and either approved for acquisition by utilities or identified as potential power plant sites pending further analysis. 21

A shortfall in the Fund's revenues in FY76 due to reduced consumption of electricity in Maryland may affect the state's site acquisition program, at least temporarily. ${ }^{22}$ Electrical demand growth rates, typically around 7 to $10 \%$ annually before the $1973-74$ energy crisis, dropped to the $-1 \%$ to $+2 \%$ range, but by late 1975 had increased again to the $5 \%$ to $6 \%$ range. $^{23}$ Maryland's utilities are considering joint ownership of new nuclear generating facilities in order to share the costs of meeting the new upturn-in demand with more limited capital outlays by each individual company. 24 No major new resources will be needed from the Fund for site acquisition because subsequent

An amendment has been sought to elininate reimbursement from the Fund to utilities because it conflicts with the legislative mandate to prevent dissipation of funds, is difficult to administer, and has not been considered very successful. 25 This amendment has been proposed several times in the legislature but has not yet been enacted. A. 1976 proposed amendment to the Act would establish a revolving account within the Fund to provide financial loan assistance to local governments for certain expenses attributable to power plant construction when assistance cannot be readily provided by other means. This would alleviate the cash flow problem between construction, when funds are required for local government services, and the time when property taxes begin accruing after the power plant begins operations. 26 
site purchases will be funded from the sale of previously-acquired sites. 27.

Site acquisition appears to be the only part of the Maryland Power Plant Siting Program which is behind schedule. This delay has been due, in part, to local opposition and, in one case, to federal delay in the state's purchase of federal land. However, state officials expect to acquire the mandated minimum number of four sites by $1979 .{ }^{28}$ Land held in the Site Bank at the expiration of the surcharge in 1985 will continue to be available to utility companies as alternatives until the Site Bank inventory is exhausted. 29 By 1985 , it is expected that the slate will own two sites available for acquisition by utility companies, and will have identified and investigated two additional alternative sites. 30

Maryland's utilities have been applying for PSC certificates for construction of power plants at a rate slightly greater than one per year for the state as a whole. ${ }^{31}$ Most recent applications have been for fossil fuel power plants. To date, no applications have been received from utilities to buy or lease state-owned sites, as utllities have proposed to build on land which they already own. 32 The state's 1976 report on the status of its Power Plant. Siting Program set forth the philosophy behind the law in these terms:

"It is concluded that the state should have the responsibility for all aspects of the assessment of specific sites and power plants except for some aspects related to radiological health and safety, *

*

* With regard to nuclear power and radiation, the PPSP report notes that "Actual radiological impacts will be estimated blemrlally for the Cumulative Environmențal Impact Report, and projected ahead for a ten year period...The PPSP radiological monitoring efforts now rely upon Department of Health and Mental Hygiene personnel in the Radialion Chemistry Laboratory to carry some of the sample analysis work load, and personnel in the Division of Radiation Control provide manpower for routine sample collection. Both functions are now undermanned, diminishing the capacity to perform the desired number of analyses and making it infeasible to collect certain samples from the Peach Bottom site and the Eastern Shore on a routine basis... It is unlikely that any new nuclear plants will commence operating in or near Maryland before 1985, and thus require operational phase monitoring by PPSP before the Environmental Trust Fund's surcharge is discontinued in $1985 . " 33$ 
and that the state, not the applicant, should decide on the significant issues to be addressed at a given site...it is necessary that the agency given authority over siting have the responsibility for providing adequate energy at reasonable costs as well as for protecting the environment."34

In assessing the highly integrated nature of the research effort, the report states:
"Many pressing questions are inherently interdisciplinary and cannot be solved by engineers, biologists or economists working independently. Several features of the law represent a new philosophy in environmental control which is beginning to emerge in some of the states. Maryland, for one, is starting to use the powers of state government to solve environmental problems. This contrasts with the past when these powers were used solely to restrict and regulate the activities of its citizens and subdivisions." 35

Directors of the Maryland siting program work closely with federal.

agencies, particularly the Nuclear Regulatory Commission (NRC). Administrators reportedly are pleased with the degree to which this federal agency recognizes Maryland's capability in power plant siting issues. For the Douglas Point nuclear plant proposed in the state, a partnership airangement will allow a joint hearing to be held between the state's PSC and federal NRC.

This streamlining of the federal/state hearing process is meant to avoid duplication and would provide a single forum for public participation. Maryland is the first state to have devised this procedure with the NRC, although New York State is a likely second candidate. These arrangements did not require new legislation, and have been accomplished by signing a "protocol" between the state and federal agency. ${ }^{36}$ other streamlining features desired by PPSP administrators to hasten approval procedures include federal legislation for "early site certification." This would give federal approval to a nuclear site early in the application process, a procedure not now possible. 
Although Maryland's Power Plant Siting Program is complex, bringing in several diverse state agencies and scientific expertise, its Director feels it operates easily. He attributes this success primarily to the program's unique funding and adequate budget, which allow it to obtain "the best available talent in Maryland." 37

Ongoing debates exist in Maryland, as elsewhere, regarding the inherent conflict between energy and environmental needs. However, broad public support seems to exist for the PYSY, and there is wo perceptiblc citizen objection to the monthly surcharge used to operate the program. Utilities feel that the PPSP has operated in their interest, as well as in the environmental interest, and that confrontation over siting has been minimized under the state's program. 38

A Joint Legislative Committee on Power Plant Siting, established in 1974 by a resolution of the legislature, was given the mandate to evaluate the PPSP. In its report of November 1974 it concluded that the program was functioning in the manner anticipated by the statute creating it. 39 This committee, having fulfilled ils legislative mandate, is no longer functioning.

The Issue of Citizen Participation. Although Maryland's pioneering siting legislation generally elic1ts favorable comment, some basic concerns have been raised about the role of citizens and local governments under the statute. The National Environmental Policy Act. (NEPA) requires that local objections to proposed sites be considered. In Maryland's dectslutluaking process, the forum for this consideration is the PSC hearing held prior to issuance of a Certificate of Public Convenience and Necessity, the license 
needed to construct the facility. This step, however, comes only at the end of

a lengthy site evaluation process, in which no citizen nor local government

inputs whatsoever have been mandated. Under the law, sites are not subject to.

local zoning or similar land development controls.

A study of citizen participation under the Maryland Act reached the

following conclusions:

"The nature of the PSC places this agency in a difficult position to achieve full objectivity in their proceedings. The PSC is responsible for assembling and evaluating the long range plans of Maryland's public utilities regarding generating needs and means for meeting these needs. The ten year plan is the PSC's based on the electric company's recommendations....

What might be the single most important set of data of the ten-year plan is the summary of the projected annual growth rates as predicted by the electric companies. These statistics were the source of serious controversy at the PSC hearing for the Dickerson expansion. Local government has no significant role in compiling this data. Since demand forecasting is not an exact science the electric companies receive the benefit of the doubt in their predictions....

Normally the PPSP holds private meetings with local officials to explain the details of the power plant. Then public information sessions are held for the community at large to explain the arrangements. These meetings are not hearings, but consist of a general questions and answer format with officials from the DNR and the electric company. There is an important distinction between information sessions and hearings. The latter includes a process of rejection or acceptance with rights of discovery for the participants...

The PSC hearings are held in the area where the site is located. The participants are the applicant, the concerned local government and relevant state agencies. Private groups having an interest in the
proceedings can intervene at the pleasure of the PSC. A Peoples' Counsel* is available to assist these groups or any interest of the public in general that arises in the hearings... Prior to the hearings for a certificate, local agencies are only consulted on environmental matters 'when appropriate'....

It is difficult to evaluate the role of the Peoples' Counsel in the proceedings...it is questionable if the Peoples' Counsel has the resources to be a competent adversary of an electric company in these proceedings." 40

*The Peoples' Counsel, provided for under the Public Service Commission Law in 1955, is appointed by the Governor to represent consumers before the PSC. 41 
This study offered several recommendations, including:

"There should be included with the utilities' ten year plans detailed explanations on how the figures on future energy consumption. were compiled. This data should be forwarded to the county governments and hearings should then be held on the reliability of the forecasting techniques, with an aim towards alternate and more accurate methods to be employed....

Local officials should be included in the preliminary and detailed site investigations by legal right, and not 'when appropriate.' Research they perform on sites should be subsidized from the Environmental Trust Fund as are the utility companies research expenses....

Full discovery procedures, including the use of interrogatories, should be available at PSC hearings for participants....

A change in the rules should be considered to allow. a person not affiliated with the PSC to sit with the hearing examiner and participate in the recommendations to the commission."42

Any innovative and far-reaching statute, such as Maryland's, should be expected to encounter its share of frustrations. From the PPSP Administrator's perspective, protracted citizen intervention is seen as contrary to some of the basic reasons for which the law was established: to provide a scientific and rational basis upon which to make energy facility siting decisions, and to avoid narrow local prerogatives from prevailing in an issue with statewide and reglonal ramifications. This is perhaps the crux of the siting dilemma of how to Incorporate legitimate citizen and local government concerns in a timëly and meaningful manner. The Issue of Facility Coverage. Maryland'a oiting laṭ rnvers only electric generating facilities and their related transmission lines; it does not include other energy facilities such as oil refineries or pipelines, which are addressed in subsequent coastal protection legislation (described subsequently). A 1975 adninistrative reorganization of DNR consolidated the 
Power Plant Siting Program, Coastal Zone Management Program, and Coastal Facilities Review Program into a single Energy and Coastal Zone Administration. While this reorganization was supposed to ensure coordination of energy-related decisions pertaining to offshore oil mining, power plants, and other energy facilities, the new administration received no new legislative mandate to carry on long-range planning for other kinds of facilities as is now done only for power plant siting. 43

\section{The Coastal Facilities Review Act of 1975}

The state's Coastal Facilities Review Act (CFRA) was initiated by the Maryland Bar Association and supported by the Maryland Environmental Trust (IET), a statutory environmental advocacy organization funded by the state and operated independent of DNR. MET has sizeable influence in state policy matters. *

When the coastal protection proposal was first brought to the legislature, it encountered strong opposition from oil companies who termed it "a blueprint for a no-development plan." To break the deadlock, a compromise was proposed to exclude the City of Baltimore from the regulatory domain of the act. This was desired by municipal and energy interests because the Crown Petroleum Company wanted to build an oil refinery in Baltimore; inclusion of the City within the Act could have had a serious impact on this proposal. Crown lobbied very hard and had the support of Baltimore City officials. Delegate Steven Sklar (Democrat, Baltimore City), the General Assembly's representative to the legislative energy organization of the National Conference of State

*

CFRA was sponsored by all the House of Delegates committee chairmen, plus the Speaker. Delegate Arnick, Chairman of the Environmental Matters Committee, was the lead sponsor. 
Legislatures, pushed for amendments to CFRA which would eliminate local veto power. Sklar felt that the state should have final authority over its often parochial subdivisions (counties and municipalities). However, because the bill did give veto power to counties over unwanted oil and gas facilities, it was not resisted as vigorously by the Maryland Association of Counties as might have been the case without veto power.

Two major ingredients thus provided the keys to passage of this legislation. The first was exclusion of Baltimore City from CFRA's control (although the city agreed to come under the Act once the Crown Petroleum facility became a fait accompli). The second important palliative gave counties authority to preclude those facilities they did not want from locating in their areas.

In any analysis of Maryland's land use laws which affect energy facility siting, an understanding of state/local relationships is essential. Counties are powerful in this state for various reasons. They are large entities in terms of geography and population. Moreover, while most counties do not have legal home rule and must rely on the state legislature to pass local ordinances, a tradition has developed whereby county delegations can request - and generally receive -- exemptions from statewide legislation, or can modify the statute to include special conditions for a particular county. These practices have led to the organization of the legislature by county delegations, and to formation of interest groups along county lines. 45

\section{Regulatory Authority Under CFRA}

Maryland enacted CFRA in May 1975, thereby mandating permits for construction of facilities related to crude oil and natural gas in areas adjacent to the Atlantic Ocean and Chesapeake Bay. The act's stated purpose is to allow for 
adequate planning of oil-related facilities in order to minimize adverse impacts and resolve conflicts among coastal uses, while at the same time providing for adequate development of energy sources. CFRA's coverage includes 16 of the state's 23 counties and comprises 6,400 square miles, approximately 65 percent of the state's total land area. ${ }^{46}$ The act regulates the following facilities:

-- offshore pipelines;

-- production terminals or refineries designed to process at least 10,000 barrels of crude oil per day;

-- oil storage facilities of a total design capacity at least 100,000 barrels per day;

-- any operations which include port or harbor facilities, occupy at least 25 acres, and are used as assembly areas to supply offshore oil and/or gas exploration.

Applications for CFRA permits must be filed with the DNR Secretary. Fees are set to reimburse DNR for costs incurred in filing and processing applications. Approval of the application by DNR is deemed to be action taken on all other permits and licenses required by other state and local government agencies. Prior to acting on the permit, DNR must review a statement of the economic, fiscal and environmental impact of the proposed facility drawn up by parties selected by the Secretary after receiving advisory comments from the Departments of State Planning, Health and Mental Hygiene, Economic Development, and Transportation. The Secretary must make this statement available to the public within 18 months after selection of the party or parties to prepare it. The application may not be processed until the county government in which the facility is proposed certifies that all local land use classifications necessary for the facility have been or will be granted. (Concern has been expressed by state officials because no specified time limit is established for receipt of 
the county's statement.) The CFRA permit procedure thus gives both the state and county governments veto power over any proposed facility.

Within 60 days after the DNR statement has been completed, DNR must hold at least one public hearing in the county in which any part of the facility would be 1ocated. All pertinent information must be made available to the public prior to this hearing. Within 90 days after completion of public hearings, the DNR Secretary must make a decision in writing. This action requires a review of certain enumerated criteria, and it is during this second tier of review that siting decisions under CFRA are coordinated with other state programs and policies.

The Socretary in rearhing a declstum must consider the burden which the facility would impose on various public services and facilities, and whether the proposed project would be consistent with the State's Coastal Lone ManagentenL Plan(s) and Development Plan(s). Perhaps the most restrictive criterid are those relating to the environmental impacts of a project, including the requirement that the Secretary determine that the facility "...would have no matertal adverse effect upon the natural environment of the area, its scenic or natural beauty, rare or irreplaceable natural resources, or unique histor1c sites." Comment on and Criticism of CFRA

Maryland's enactment of CFRA was a direct response to proposals by oil interests and the federal government to lease tracts in the Atlantic ocean's Outer Continental Shelf. Indeed, the legislation makes specific reference to exploration in the Baltimore Canyon Trough area..

CFRA is not a comprehensive siting law. The act provides a mechanism for reviewing the impacts of a particular facility on a given site, but makes no commitment to long-range planning or to finding appropriate sites for oil 
development (as does the PPSA for power plants). Legislation was proposed to. use the same PPSA mechanism for oil facility siting, including state acquisition of sites; it was defeated in committee. However, CFRA does recognize that "meeting the energy requirements of the state and nation and planning for the proper use or development of the coastal zone is imperative;" that for faciljties of regional impact and/or benefit "the state interest and the national become a factor in the consideration of where these oil-related facilities shall be located;" and that "the national public interest in assuring adequate facilities for the production of energy resources requires that the state and local governments promptly and expeditously assess the impact of these facilities and determine, at the earliest practicable time, whether to grant necessary state and local authorizations."

CFRA is a reactive mechanism under which proposed developments can be rejected. Under this law, however, the state cannot force a facility to be located in an unwilling county. The state retains the option, of course, of initiating judicial review if it appears that a local decision is arbitrary. However, a 1975 court decision in Maryland upheld the right of a county, by local law, to prohibit an oil refinery within its borders. ${ }^{47}$ This perhaps sets an important judicial precedent for later CFRA decisions.

Both New Jersey and Maryland enacted their coastal protection laws pursuant to the federal government's Coastal Zone Management Act of 1972. There is one important difference between the two states' legislation, however. The Maryland act is more limited in that it controls only crude oil and natural gas operations, whereas New Jersey's CAFRA legislation also covers all major facilities for generation of electrical power, specifically including nuclear facilities. (Of course, electric generating facilities are covered in Maryland under the PPSA:) 
In addition, the New Jersey law covers a wide variety of major non-energy industrial facilities; new housing developments of 25 or more dwelling units; and sewage facilities -- none of which are addressed in Maryland"s coastal statute. New Jersey does not, however, have any statewide energy facility siting law, although several are pending in its state legislature.

\section{Other Legislation Related to Energy Facility Siting}

Wetlands Act

The Wetlands Act of 1970 differs from similar laws in other states in that it divides wetlands into two categories: "state wetlands" and "private wetlands." State wetlands are any land under the navigable waters of the state below the mean high tide. Private wetlands are those not considered state wetlands and which border on or beneath tidal waters subject to regular or periodic tidal action and support aquatic growth. A 11cense from the Board of Public Works is required to dredge or fill in any state wetland. The DNR Secretary, in consultation with the Maryland Agricultural Commission, designates the wetlands within the state, holds public hearings and promulgates rules and regulations for use of private wetlands based upon the value of the particular area. A permit is required in private wetlands to conduct all but certaln specified activities. Among these are the right to make improvements on the 1and; to preserve access to navigable waters; to protect against erosion; and to reclaim "fast" land (land lost by erosion). Specific provision for compliance with these dredge and fill regulations is made in the state's Power Plant Siting $\Lambda \mathrm{ct}$.

According to an explanation in the legislation, this act represents Maryland's first substantial change in riparian ownership rules in over 100 years. Tt repealed the long-standing Act of 1862 which was the basis of 
riparian rights during the previous century.

Flood Plain Law

The Flood Hazard Management Act of 1976 was enacted by the legislature and signed into law by Governor Marvin Mandel in May; its effective date was July 1, 1976. The stated purposes of this act are:

"to assist in the guidance of development to minimize the impacts of flooding; to delineate interim flood hazard areas and designate allowable uses; to provide state guidelines and technical assistance to local governments in management of flood hazard areas; to provide for comprehensive watershed management; to facilitate implementation of projects for flood control; to encourage and provide for local governmental units to manage flood-prone lands in a comprehensive manner; and to provide for the biological and environmental quality of the watersheds of the state."

By January 1, 1977, after consulting with counties, municipalities, and the Departments of State Planning and Agriculture, DNR was to divide the state into watersheds for detailed study. At the same time, DNR must prepare maps indicating interim flood hazard areas (areas of tidal or non-tidal inundation resulting from a 100-year flood). Maps are to be completed by April 1, 1977, and, after public hearings in the appropriate county, DNR must adopt each interim flood hazard area map as a rule or regulation (by August 1, 1977). By November 1, 1978, every county and municipality must adopt regulatory legislation governing uses within these designated areas, based on criteria including the impact on planned development. Alternatively, local governments may request that DNR prepare such rules and regulations for them.

Subsequently, the final Flood Hazard Area maps for each watershed will supersede the interim maps, and the original procedure of public hearings and adoption of final local regulations will have to be repeated. Implementation of flood management plans must begin within one year of completion of these final maps. The act requires a continuing flow of information from counties and 
municipalities to DNR on local development, changes in land use, and other physical changes. DNR must report to the Governor and legislature every two years on its implementation progress under the act.

Although the preceding statutes are the principal considerations for energy facility siting in Maryland, several additional laws indicate legislative concerns and activity and constitute an integral part of the overall land use/ siting picture in the state.

Environmental Policy Act

The Maryland Environmental Pulicy Act of 1973 mandatcs that all state agencies prepare an environmental effects report for each proposed state action which significantly affects the quality of the environment. The act articulates state policy in this manner:

\footnotetext{
"The protection, preservation, and enhancement of the state's diverse environment is necessary for the maintenance of the public health and welfare and the continued viability of the economy of the state and is a matter of highest public priority;
}

A11 state agencies must regulatc their affairs with an awareness that they are stcwards of the air, land, water, and living resources, and that they have an obligation to protect the environment for the use and enjoyment of this and all future generations;

Each person has a fundamental and inalienable right to a healthful envịronment, and each person has a responsiblity to contribute to the protection, preservation, and enhancement of the environment;

The policies, rules, regulations, and public laws of the state shall. be interpreted and administered in accordance with the policies set forth in this act." 48

\section{Areas of Critical State Concern}

In 1974, the legislature empowered the Department of State.Planning to designate areas of critical state concern based upon recommendations of 
municipalities and counties. It is anticipated that, by July 1, 1978, local governments will incorporate such areas in their plans. Critical areas are those which because of location, pending development, or suitability (geology, soils, acreage, water availability) are considered potential sites for major facilities or intensive development. The Department also was given powers of intervention in certain planning issues.

These two features (critical areas designation and intervention) were the only ones which survived the defeat in 1974 of an overall state land use bill which would have given the state authority to pre-empt the prerogatives of counties and municipalities. 49

Permit Procedures and Requirements

In 1975, the state legislature enacted Consolidated Permit Procedures legislation intended to streamline the permit process and allow citizens to participate more readily in the proceedings. This law calls for a joint permit hearing to be held for a project. requiring more than one permit. If the local government(s) involved so desire, this can be a joint hearing for local and state permits; if the local government opts out of the procedure, it will be a hearing for state permits only.

The title of the process is somewhat misleading, for no consolidated permit is issued. Each permit decision is still made separately by different agencies, the application and hearing stages being the only parts "consolidated." Nevertheless, every state and local agency involved will be aware of the concerns of other agencies. The cumulative impacts of any project may be considered at the hearing. While no new decision criteria are added, several of the existing permitting decisions can be based on broad discretion of the agency involved (for example, a water appropriation permit), and this process 
may make available to these agencies decision data which they might not ordinarily consider.

An amendment to the state's Water Code in 1974 required a permit to appropriate or use state waters. Although it works in tandem with provisions of the Power Plant Siting Act, this permit requirement is worthy of mention because of the importance of water use to energy facility siting. This act states:

\footnotetext{
"In order to conserve, protect, and use water resources of the state in accordance with the best interests of the people of Maryland it is the policy of the state to control, so far as feasible, appropriation or use of surface and underground waters of the State."
}

A DNR permit is required for appropriation or use of state waters, or to build any plant, building or structure which might appropriate or use any waters of the state. The burden of proof is on the applicant to show that the use will not jeopardize the state's water quality or natural resources. Farming and individual domestic use of water are exempted from this permit system. Various other state permits are required pertaining to: oil handling (primarily to ensure that oil spill prevention measures are in effect); grading and sediment control; air quality; and so on. These permits are all included in the one-stop process established under the Power Plant Siting Program, which uses state and federal standards as its basis, but some are still issued independently of the PSC.

\section{Other Energy-Related Legislation}

The $19 / 4$ session of the Maryland General Assembly wltnessed an Lupressive legislative response to the energy crisis of the winter of 1973-74. Most bills were drawn hastily in an emergency atmosphere, but were not enacted by the legislature due to the fact that the crisls attltude quickly dissipated with 
the ending of the OPEC oil embargo and the return of warmer weather. 50

Interestingly, many of the bills proposed in 1974 had a single sponsor, Delegate Steven Sklar of Baltimore.*

The 1974 session did see enactment of the following energy policy measures:

- Removal of the oil depletion allowance as a deductible item in state taxes;

- Divestiture of oil companies' ownership of gas stations; 51

- Amendment of the State Model Performance Building Code to promote efficient utilization of energy resources;52

- Passage of a Resource Recovery Loan Act to encourage conservation of energy and other natural resources, and to assist local governments in reducing the costs of solid waste disposal; the bill established a $\$ 5$ million loan mechanism to foster recycling; and

- Amendment of the criminal code such that false representations to the state in connection with an energy crisis or in the allocation of energy supplies will be punishable by imprisonment and fine.

A series of additional energy-related bills became law in 1975 and 1976;

- Emergency powers were granted to the Governor to deal with an actual or impending acute shortage of energy resources. This law was originally enacted in 1974 as an energy amendment to powers granted the Governor for emergencies in 1968 after the occurrence of racial riots. It has been renewed again at one-year intervals through March 1977;

- A bill was passed to further the state's efforts in developing a solar energy program. Solar energy units used in buildings are to be assessed equally with conventional heating and cooling units, thereby encouraging use of solar energy.

- Radiation control matters were placed under the jurisdiction of the Department of Health and Mental Hygiene, which is to develop comprehensive policies and programs for evaluation and determination of radiation hazards and their amelioration.

- A study of the Public Service Commission's rate structure policies was mandated.

*

Sklar also supported CFRA's passage with strong state authority vs. local veto power, although the veto power mechanism prevailed. 
One additional item of energy-related legislation was vetoed by the Governor in May 1975 after its passage in the legislature:

- Downgrading of state air quality standards in Allegheny and Garrett Counties, particularly for fuel-burning stationary sources.

This bil1 had caused a great deal of controversy in the legislature, where some legislators felt that the details of air pollution standards should be handled within the executive branch, not in the legislature. Veto of this legislative initiative allowed the executive branch to adjust Maryland's air quality standards on a case-by-case basis. 53

Maryland has an Energy Policy Office, established by Executive Order at the height of the energy crisis in November, 1973. This office currently has a staff of 12 , and an annual budget of $\$ 250,000$. The primary functions of this agency are public information and education, conservation, fuel allocation and policy analysis. Staff members have testified at the legislature on energy bills, and the office is in a position to provide information to legislators. However, this has not occurred with any frequency because the legislature has viewed this agency as one established on a temporary basis during the crisis, and indeed they have attempted to end its funding on several occasions. Thus, while the Maryland legislature has been innovative in energy facility siting, it has not taken full advantage of an existing mechanism to allow the state to move more rapidly on other energy issues. 54

\section{Eonclustons}

In assessing Maryland's record on energy legislation, one is immediately impressed with the state's imaginative and unique power plant siting law enacted in 1971, well in advance of the national energy crisis of 1973-74. As noted, procedures in the siting program could be altered to accommodate earlier local 
government and citizen inputs in the decision-making process. Although the state now has a coastal protection law, its CFRA is a reactive mechanism which does not mandate long-range planning strategies for that area as is done for power plant siting or, for example, as does New Jersey's CAFRA.

The legislature also has several other energy proposals before it, many relating to the PSC and rate structures. These are a response to the increasing costs of energy and to the political pressures to do something about these price increases. Many of these proposals will be studied.further, and may be reconsidered in the 1977 legislative session. Issues such as energy conservation have not yet been translated into legislation in any comprehensive manner, although some steps taken do indicate legislative interest.

Maryland's legislature has been described as innovative, and this characteristic will most likely lead it to seek further enlightened solutions to the energy dilemma. In addition, the legislative and executive branches of government in this state are under the control of the same political party, and they appear willing to cooperate where energy policy is concerned. This contrasts with New Jersey, for exampie, where serious intra-party dissention between the two jurisdictional branches of government on energy and other issues has prevented effective formulation of state energy policy. 
1. Interview by Grace Singer, Princeton University Center for Environmental Studies Researcher with John J. Szymanski, Legislative Analyst for the Environmental Matters Committee of the House of Delegates and for the Department of Legislative Reference, State of Maryland, May 2:, 1976 .

2. Ib id.

3. Ib id.

4. National Science Foundation, Office of Energy R \& D Policy, Proceedings of Meetings of Advisory Committee on Energy Facility Siting Held on October 24, 1975 (Washington, D.C.: U.S. Government Printing Office, February, 1976), p. 86 .

5. Execullve urder kistahlishing Tark Forec on Plucleul Puwer rlanes, July lygy.

6. Governor's Task Force on Nuclear Power Plants, Nuclear Power Plants in Maryland (Annapol1s, Md.: Task Force, December 1969), p. 5 .

7. Ibid., pp. 12, 14 .

5. Interview by Singer with Lee Zeni, Director of Energy and Coastal Zone Administration, Maryland Power Plant Siting Program, May 28, 1976.

9. Annotated Code of the Public General Laws of Maryland, 3-301.

10. Interview with Szymanski, op. cit.

11. Interview with Szymanski, Ibid.

12. Congressional Research Service, Library of Congress, Energy Facility Siting in Coastal Areas, Report prepared for the use of the Committee on Commerce. U.S. Senate (Washington, D.C.: Deiculuer, 1975), p. 65 (Maryland analysis by $W$. Wendell Fletcher, CRS analyst in Environmental and Natural Resources Policy).

13. Ib id.

14. Interview with Zeni, op. cit.

15. Ibid.

16. Interview by Singer with Simon F. McHugh, Jr., Execulive Assistant to Blair Lee III, Lieutenant Governor of Maryland, May 28, 1968.

17. Lee Zeni, "Maryland Pioneers State Siting Program", Electrical World, April 1, 1976, p. 32.

19. Maryland Power Plant Siting Program, Annual 10-Year Report (Annapolis: PPSP, May 1976), p. 1. 
19. Ibid.

20. Ibid., p. 16 .

21. Maryland Power Plant Siting Program, op. cit., p. 68.

22. Ibid., p. 16 .

23. Ibid., p. 41 .

24. Ib id.

25. Tbid., p. 15 .

25. HB694.

27. Maryland Power Plant Siting Program, op. cit., p. 71.

28. Interview with Zeni, op. cit., January 25, 1976.

29. Maryland Power Plant Siting Program, op. cit., p. 68.

30. Interview by Singer with Paul Masicott, Director, Power Plant Siting Program, February 24, 1977.

31. Ibid., p. 43 .

32. Interview with Zeni, op. cit.

33. Maryland Power Plant Siting Program, op. cit., pp. 31 and 33.

34. Ibid., P. 12 .

35. Ibid.

36. Interview with Zeni, op. cit.

37. Ib id.

33. Ib id.

39. Maryland Legislature, Joint Committee on Power Plant Siting, 1974 Report to the Legislative Council of Maryland (Annapolis: Maryland Legislature, November 19, 1974), pp. 6,7.

40. Philip Ochs, A Preliminary Study of Citizen Participation Under the Power Plant Siting Act (Toledo, Ohio: University of Toledo Law School, September 13, 1974), pp. 5-8, 12-13 and 15.

41. Letter to Singer from John J. Szymanski (op. cit.), June 8, 1976. 
42. Ochs, op. cit., pp. 22-23.

43. Letter to Singer from Margaret R. Johnston, Maryland Energy and Coastal Zone Administration, March 17, 1976.

44. Interview with Szymanski, op.cit.

45. Maryland Energy and Coastal Zone Administration, Annual Report: 1976 (Annapolis: MECZA, 1976).

46. Maryland City and County Date Book (Annapolis: State of Maryland, 1967), p. 162 .

47. Report from Edward F. Lawson, Esq., Special Assistant Attorney General for the Maryland Department of Natural Resources (Energy and Coastal Zone Administration), July 7, 1975, p. 5.

48. Annotated Code of Maryland, op. cit., 1-302, pp. 32, 33.

49. Interview with Szymanski, op. cit.

50. Interview with McHugh, op. cit.

51. Ibid.

52. Ibid.

53. Interview with Szymanski, op. cit.

54. Interview by Singer with Peter V. Stanton, Public Information Officer, Maryland Energy Policy Office, August 2, 1976. 


\section{NEW YORK: FOCUS ON POWER PLANT SITING}

The overriding issue in New York state since about early 1975 has been the serious financial crisis in New York City and in the state as a whole. While the New York legislature passed a power plant siting law in 1972, the financial issue has precluded enactment of much other energy legislation, including serious energy conservation measures. The almost-total absorption of state officials with the financial issue, and a lack of clear energy policy and guidelines on state and federal levels, are both evident constraints on such legislative action.

\section{Legislature Structure}

New York's legislature does not have standing committees devoted solely to energy, although the Assembly's Environmental Conservation Committee has a Subcommittee on Energy. There is no equivalent body in the Senate.

Over the years, the legislature has established several special commissions to study energy policy. For example, a commission was created in 1970 to lay the basis for enactment of the state's present power plant siting statute; ${ }^{1}$ and in 1972, a new commission emerged in companion legislation to the siting statute. A Joint Legislative Commission on. Energy Policy was created in 1973 to formulate comprehensive energy policy for the state and to study the Public Service Commission's rate proceedings, among other matters.

In 1975, a new Commission on Energy Systems superseded the Joint Legislative Commission; it too was charged by the legislature to investigate and formulate energy policy for the state. This latest commission works closely with the Assembly's Energy Subcommittee. Both groups are 
chaired by Assemblyman Daniel Haley (Democrat, St. Lawrence and Franklin

Counties). "A report made to. the Joint Legislative Commission by its Scientific Advisor, Establishing an Energy Policy for New York State - 1975, offered a wide variety of proposals on energy conservation and on alternate sources of energy. Work on this subject is continuing under the aegis of the newlyrestructured commission. ${ }^{2}$

New York's legislature has a very large number of standing committees (53), partly reflecting the state's complexity and size. As a comparison, there are 20 legislative committees in Maryland, 33 in New Jersey and $3 \%$ in California. ${ }^{3}$ Proposed legislation can be directed by the leadership of each house to any of a number of these committees, depending upon the specific subject. ${ }^{4}$ These include:

In the Assembly:

Consumer Affairs and Protection

Corporations, Authorities and Commissions

Environmental Conservation

Governmental Operations

Rea1. Property

Transportation

Ways and Means

Tn Lhe Sellate:

Conservation and Recreation

Consumer Protection

Corporations, Authorities and Public Utilities

Finance

Taxation

Transportation.

Often, energy legislation will be received by more than one committee in each house. For example, after deliberation by the Assembly's Environmental Conservation Committee, bills will be sent to the Ways and Means Committee for financial decisions.

*Defeated in the November, 1976 election. 
Legislative sessions have been getting busier and longer each year. The 1976 session witnessed an avalanche of $1,800 \mathrm{bil1s}$, over 100 of them relating to energy. 5 Most proposed energy legislation falls into one of three major categories: energy conservation, alternate energy sources and rate structure.

Each house of the New York legislature has staff members who handle energy research, and each can call on the research capabilities of the Public Service Commission (PSC) or the Emergency Fuel office (which functions to some degree as the state's Energy office). According to Dr. James Monroe, Executive Director of the Commission on Energy Systems, lack of research capability has not been a serious problem in New York state; the lack has been in setting energy as a priority issue in order to formulate sound policy. 6 Legislative Activity on Energy Issues

Energy Research and Development Authority

The most significant energy legislation enacted in 1975 established the state's Energy Research and Development Authority (NYS ERDA), a reconstitution of the state's Atomic and Space Development Authority (ASDA). ${ }^{7}$ The Authority's prime purpose is to accelerate development and use of new energy technologies as a supplement to existing sources, and to promote energy conservation. NYSERDA's legislative mandate emphasizes safe, renewable sources such as solar, wind, bioconversion and solid waste. Its creation as a replacement for ASDA indicates a shift in emphasis in New York away from reliance primarily on nuclear energy.

State Energy Office

Also significant was the passage in July, 1976, of legislation creating a State Energy Office (SEO) with comprehensive planning and coordinating authority. ${ }^{8}$ The SEO supersedes the state Emergency Fuel office (EFO), established originally 
to facilitate a fuel allocation program during the energy crisis of 1973-74.

In the absence of a comprehensive SEO, which went into effect at the end of

August 1.976, the EFO had been carrying out other energy work. The EFO,

which had 15 employees, became the nucleus of the SEO, which ultimately

will have approximate1y 40 employees, making it the second-largest SEO in the

11 states of the Northeast (only Connecticut"s 46-member energy agency is

Iarger).

The SFO legislation emphasizes energy conservation, setting forth its

purpose as follows:

"The legislature hereby finds and declares that the people of New York State have suffered shortages of all forms of energy; that such shortages are likely to recur; that New York is overly dependent on sources of energy from outside the state; such shortages and high costs have been inimical to health, safety and welfare of the people.

The state must therefore take steps to meet these shortages and high costs by cutting energy waste and reducing energy consumption; by insuring fair and efficient distribution of supplies in emergencies; and by promoting the use of indigenous renewable sources of energy wherever possible. It must do so by minimizing the risk to human health and the environment, and by maximizing the benefits to New York labor, business and industry. Toward these ends, research and development efforts of the New York State Energy Research and Development Authority and the regulatory functions of the Public Service Commisslun musl be coordinated with conservation and energy management programs. A11 of these must be accompanied by expanded public education, and, whitu necessary, mandatory restrictions on uses of energy.

The legislature finds that existing state programs relating to energy development, consumption, conservation, research and education are dispersed among various state agencies with no one office bearing the responsibility of overall management and coordination of the state"s energy program. It is, therefore, the intention of the legislature to create a State Energy Office to work with the Energy Research and Development Authority, the Public Service Commissiun, and other state departments to assure development and coordination of an overall state energy program."

Passage of legislation to establish the SEO and to implement various energy conservation measures places New York in a favorable position to receive federal assistance and guidance in the series of proposed national energy 
conservation programs included in the Energy Policy and Conservation Act of 1975, and in subsequent legislation enacted in August, $1976 .^{10}$

In the interaction between the legislature and the Governor's office prior to passage of this law, concerns were expressed about the SEO not receiving adequate funding, thus preventing it from being the strong, effective office envisioned by many. In 1975 , the EFO had a budget of $\$ 350,000$, which was eliminated by the legislature in 1976, primarily because the EFO was perceived as a temporary emergency office with limited functions. The amount proposed for the 1977 budget is $\$ 850,0000^{11}$

By creating the State Energy office through executive order, the Governor could have exercised greater control over its functions, since he could rescind the order at his discretion. Most state energy offices were created in this manner after the crisis of 1973-74. However, these operations were generally limited to fuel allocation, and they often utilized personnel from state civil defense offices. They did not encompass the comprehensive functions envisioned for New York state in the areas of energy conservation and other complex energy policy matters, issues on which a legitimate legislative mandate - such as the new New York SEO now has -- are of particular significance. This compares with the situation in New Jersey where an SEO is established by executive order and, lacking legislative mandate, has been relegated to a minor role in energy planning.

\section{Oil and Gas Leasing in State-Owned Lands}

Leasing of state lands under Lake Erie for production of gas was proposed in February 1976 and passed by the State Senate on May 13, $1976 .^{12}$ As of January 1977 the bill was being considered by the Assembly's Environmental Conservation Committee. By amending current law prohibiting such drilling, 
the measure would permit the Department of Environmental Conservation (DEC) to let leases on behalf of the state for exploration, development and production of oil and gas in state-owned lands.

Before proceeding with its leasing, DEC must make certain explicit findings or take specific actions, including:

- determining that a shortage of natural gas exists in the state;

- describing available technology of drilling and exploration to minimize possible environmental impact due to salt or brine intrusion, oil leakage, or other pollutants;

- determining thal euvironmental impact will be "minimal when compared to potential economic benefit to the state and its residents";

- promulgating requirements to ensure that any drilling which encounters oil-bearing strata will be immediately and permanently sealed; and

- requiring that each lessee post a bond of sufficient magnitude to guarantee repair or correction of environmental damage.

Within six months of the effective date of the statute, DEC would be required to report its findings and conclusions to the Governor and state legislature. Interestingly, at the same time that New York is proposing to allow drilling for gas in Lake Erie, the Pennsylvania House of Representatives has approved a law which would prohibit such activity in the same lake because of its concern over oil spills (see chapter on Pennsylvania). ${ }^{*}$ According to Dr. Glenn Stevenson, Principal Scientist of the New York State Assembly's Scientific Staff, Canada has been conducting exploratory drilling in Lake Erie since the end of World War II. In the past 10 to 12 years Canada has drilled approximately 838 we1.1s, and currently has 300 active gas wells. These wells have yielded a high quality "very pure methane gas" which has little or no sulfur. In all of this drilling activity, there has not been a single "showing of oil" which

* As of January 1977, this legislation was pending in the Pennsylvania Senate Environmental Resources Committee. 
would indicate a meaningful supply in Lake Erie. Geologists' tests on the American side of Lake Erie have never shown more than a very slight "showing of oil," indicating a very low probability that there is any quantity of oil in the area. 13

Another bill on this subject was introduced in May and passed in the Assembly in June 1976. It would require the DEC to make comprehensive findings relating to drilling for gas in Lake Erie. Depending upon the findings, a comprehensive plan to remove prohibitions against drilling in Lake Erie, including specific rules and regulations, would be submitted to the legislature for its consideration. As of January 1977, no further action has been taken on either bill. Efforts to reconcile the two measures are expected in 1977. The Senate bill is seen as more permissive and the Assembly bill as more cautious in their approaches toward gas drilling. ${ }^{14}$ In viewing the diverse actions taken within the New York legislature and in Pennsylvania and Canada, one might wonder which is the most prudent course for the two states to take. The latter New York bill recounts some facts about Lake Erie which give insight into the possible importance of the drilling proposals:

"Lake Erie is an irreplaceable natural resource. As one of the Great Lakes, Lake Erie provides:

(a) municipal water supply for over eleven million people;

(b) industrial water supply for many essential industries;

(c) recreational opportunities, such as swimming, boating, fishing, hunting, birding, picnicing, camping;

(d) lakefront facilities for year-round residents and summer visitors;

(e) commercial fishery resources;

(f) wildlife habitats and feeding grounds for migratory birds;

(g) visual amenities and esthetic beauty; and

(h) a natural highway for commercial transport." 15

\section{Basic Delays in Energy Policy Formulation}

Considering the number of energy bills introduced in the New York legislature in 1975 and 1976, very little such legislation has been enacted. 
This reflects to some degree the state's preoccupation with other pressing issues, including the state and city financial crisis. In addition, the complexity of energy issues and lack of policy and guidelines on either the state or federal level have been a detriment to expeditious passage of some types of legislation. For example, many bills have been introduced offering incentives for use of solar power. However, no federal or state standards exist for this equipment nor are there any consumer protection rules. The EFO, functioning as the state's energy office, advised against passage of these solar incentive bills even though in agreement with their basic aim. ${ }^{16}$ The EFO contended that consumers would be buying "a pig in a poke" because the state of the art in solar technology had not yet beell adequately devcloped. Some of the legal questions which have been raised In the legislature on this issue are: What happens if a building with solar panels has a taller building constructed close by, blocking out the sun? Do you offer tax incentives for energy conservation measures, or do you levy penalties against those who do not make certain conservation moves? Another example of legislattve delay is seen in the legislature's study of energy conservation in relation to appliances. Under the federal Energy Policy and Conservation Act enacted in December 1975, the National Bureau of Standards must establish guidelines before a state can move forward with its own legislation (and be eligible for federal financial assistance). Since these federal guidelines had not yet been provided during the 1976 legislative session, action on the state level could not proceed.

Development of an energy-efficient building construction code also has been stymied. By legislative mandate, the New York Building Code Council has bcen working 
on this issue since 1974..$^{17}$ Some at the State House feel that

the problem arises from the fact that some of New York's lawmakers want to legislate details of the building code rather than allow administrative professionals to do so. In contrast, New Jersey passed a state uniform construction code in 1975 permitting the staff of the Department of Community Affairs to develop regulatory details, including preparation of an energy subcode. $^{18}$ The New York legislature did pass a "right-turn-on-red" bill pertaining to motor vehicles, which will conserve gasoline and enable the state to participate in federal funding programs, provided other measures are taken (e.g., car pooling programs). Such measures have been enacted in other states, including New Jersey.

Some disquieting feelings have been raised in some quarters in New York government that energy policy may not be getting a fair hearing in the Governor's office, and that Governor Hugh Carey himself may be reticent on certain energy issues. Governor Carey in 1975 vetoed legislation establishing a statewide system to encourage reclamation, rerefining and reuse of used oils on the grounds that it would have created another state bureaucracy. The bill had 32 sponsors in both houses of the legislature, with 20 sponsors of the same political party as the Governor. ${ }^{19}$

The Counsel for the Emergency Fuel office pointed to the farreaching implications of the state's lack of policy on urgent energy issues in a May 1976 report given at a joint public hearing of the Senate and Assembly:

"...the state should develop a position with reference to the development of the Outer Continental Shelf before the federal government takes the position for us." 20 
New York's 1972 power plant siting act sets out a comprehensive, onestop siting process. ${ }^{21}$ The state's Public Service Commission (PSC) is the lead agency, given authority under the act to supersede other state and municipal permits and approvals where necessary.

Background to the Power Plant Siting Act

The 1972. siting law was preceded by exhaustive debate in the legislature, and many compromises between utility, industry and environmental factions had to be wurked out prior to its passage. ${ }^{22}$ In an unusual reversal of the sequence of utility regulation, in 1970 New York had enacted a law limited solely to major utility gas pipeline and electric transmission lines; power planes were not included. This law provided comprehensive procedures for review of pronosed projects, including a public hearing by the PSC prior to construction. ${ }^{23}$ Enactment of siting legislation for transmission facilities prior to similar provision for power plants was the result of several factors:

(1) Transmission lines traverse many towns and counties, producing an earliel recognition of the need for a centralized permitting authority;

(2) Legislation for siting of tranemiooion lines was less cumplfcaced and less controversial than the issue of power plant aiting, resulting in greater acceptance on the part of the legislature;

(3) Aesthetics vis-a-vis transmission lines was becoming a more piumlnent public issue as population moved out of the cities into the countryside;

(4) In New York, problems had been encountered in obtaining rightsof-way and in paying the high costs for this land, giving added impetus to siting lcgislation;

(5) Power plants were not as great a public concern when they were in the 2.00 to 300 megawatt size; this changed in the transition to nuclear power and to the 1,000 megawatt power plant. 
The regulatory void regarding power plant siting was resolved in 1972 with passage of the statute providing for licensing of generating facilities.

Government interest in power plant siting in New York State can be traced back at least to the winter of 1967, when Governor Nelson A. Rockefeller made an important statement on energy. * In 1970, a special commission was

${ }^{*}$ At a news conference on March 1, 1967, Governor Rockefeller and the private utilities in New York State joined in announcing an $\$ 8$ billion spending and expansion program by the utilities for nuclear energy. The program was designed to double the power available to the state by 1977. The state's participation was to be confined largely to coordination of the expansion program. The Governor's plan, which was approved by the utilities, included establishment of a committee to define electric power needs and recommend ways to achieve the "lowest practicable costs"; authorization for the New York State Atomic and Space Development Authority (now NYSERDA) to acquire a network of sites for future nuclear plants; and continued limitation of the New York State Power Authority to hydroelectric operations to avoid competition with the utilities in the field of nuclear energy. In stating his reasons for this project, the Governor said: "Frankly, one of the most significant aspects of the program should lead to a solution of the air pollution problem". In addition he said "such developments give promise of lower costs". 24

By June of 1967, the Governor was acknowledging a "head-on impasse" with Democratic legislators on his controversial power plant expansion proposal. The Democratic leadership of the State Assembly had killed the plan in committee that year, denouncing it as a sellout to the state's private utilities. During the legislative session the Assembly Speaker, Anthony J. Travia, a Democrat from New York City, said his counter-offer to the Governor was to give the Power Authority an equal role with the private companies in the expansion program, but that this had been "turned down flatly." New York Senator Robert F. Kennedy charged that the proposal would destroy the historic role of public power in acting as a low cost yardstick to keep down the costs of private power. In a compromise statement, the Governor then said the plan would give the State Power Authority a small role in the development of nuclear power by having it join with private utilities in developing a new breeder reactor. 25

Apparently, the legislature prevailed on this issue. In 1968, the State Power Authority was authorized to construct nuclear as well as hydroelectric or fossil power plants. It functions primarily in the area of municipal electric systems and rural electric cooperatives, but also sells power to utility companies who resell it to their private customers at lower costs than would be paid otherwise; to certain specified industries; and to the Plattsburgh Air Force Base. 26 
established by the legislature to study and recommend policy on this subject.

Called the Temporary State Commission on the Environmental Impact of Major

Public Utility Facilities, it was chaired by Senator Thomas F. McGowan

(Democrat, Livingston, Wyoming and. Erie Counties.), also. Chairman of the Senate's

Public Jtilities Committee. This Commission conducted public hearings on

all aspects of the siting issue, and its final report developed five alternative

legislative proposals for further consideration in the Senate and Assembly:

1. Consolidate all state requirements for licensing power plants into three distinct. permit proceedings, one by local authorities, one by the PSC, and one by the Department of Environmental

Coneervation (DEC);

2. Require site approval from the PSC and DEC as agencies, and from a separate three-member siting panel comprised of one representative each from PSC, DEC and the local government in the area of the proposed site;

3. Consolidate state requirements into a single PSC-DEC permit proceeding, with participation by local municipalities and counties;

4. Authorize the PSC as the sole agency, but require that PSC actions comply with all state and local requirements unless a court order to the contrary were obtained;

5. Five the PSC sole authority over siting, with the DEC and local governments acting in an advisory capacity. 27

Under the Leadershlp of Semaluil MeGowan, power plant siting legislation was enacted in 1972, based generally on Alternative \#2. In companion legislation, a commission was established to formulate comprehensive energy policy for the state and to study the state's electric power program to determine necessary or appropriate changes to protect the environment, public health and safety. This Commission was also charged to make recommendations on improved procedures for siting electric generating facilities and to encourage long-range planning by regulatory agencies and utility companies. 28 
New York has been criticized for not consolidating its proceedings for approval of power plants and transmission facilities. The reason given for keeping these separate, at least for the time being, is that review and hearing procedures for transmission lines have gone through their "shake down" period and are working smoothly. This is not yet true for power plant proceedings, where none of the applications filed for Certificates to Construct have yet reached the siting board hearing stage (see below). It is generally assumed that these two sets of proceedings will be united at some future date. ${ }^{29}$ Principal Features of the Power Plant Siting Law

After lengthy deliberation, the legislature selected a variant of Alternative $\# 2$ from the McGowan Commission's options, with explicit roles given to both PSC and DEC, along with a new siting board.

The New York law is similar to siting statutes in other states in that it requires a Certificate of Environmental Compatibility and Public Need from a state agency prior to construction of power plants. In New York, this certificate must come from the Board on Electric Generation Siting and the Environment, which consists of five members: the Chairman of the PSC (Board Chairman), the Commissioners of Environmental Conservation (DEC), Commerce, and Health, and a representative appointed by the Governor who is a resident of the specific political jurisdiction in which the power plant has been proposed. * To avoid conflicts of interest, no member of the Board may hold any official relationship to, or securities of, any utility corporation operating in the state, nor may appointees have been directors, officers of employees of such utilities.

In its findings and declaration section, the 1972 law states:

* Thus this fifth Board member varies depending on the site proposed. 
"the legislature finds that existing provisions of law do not provide adequate opportunity for individuals, groups interested in conservation and the protection of the environment, munjcipalities and other public bodies to participate in a timely and meaningful fashion in the decision whether or not to locate a specific major steam electric generating facility at a specific site."

The statute attempts to ameliorate this condition by widely distributing notification of hearings of "sufficient duration" to be held in the "primary proposed location."

The hearing is conducted by a PSC Hearing Examiner, joined by a DEC Associate Examiner who may submit a separate report dissenting or concurring with the conclusions and recommendations of the PSC Examiner. The DEC is required to present expert testimony and data regarding the facility's potential impact on the environment and its compliance with state and local laws, standards, policies, rules and regulations. Parties to the hearing, in addition to DEC, include:

- the state Departments of Commerce and Health;

- the Office of Planning Services;

- affected municipalities;

- individuals who file a notice of intent within a specified time;

- non-profit conservation, consumer or industrial organizations; and

- regional planning groups such as the Hudson River Valley Commission or the St. Lawrencc-Eastern Ontario Commission (when a facility is to be lecated in their jurisdiction).

Joint hearings may be held with federal agencies when appropriate.

The Board makes the final decision on applications, and must publish the reasoning behind its decisions. DEC, as a party to the hearing, has the right to appeal, thus allowing it to assume an advocacy role. The act makes extensive provision for judicial review. Following construction, DEC is required 
to monitor the plant's air and water discharges to assure compliance with its environmental standards.

As part of its application, the utility must submit detailed site and facility descriptions for its principal site, and for at least one alternate site and mode of generation. Other data must be included on environmental impact, compliance with state and local laws and regulations, cost of the proposed facility and its alternatives, and justification of the long-range need for the facility. Alternate sites and generating sources also require both notice and hearing. The hearing process can become protracted since suggestions for alternate sites can originate from any source. The Hearing Officer then determines if the utility must submit detailed site data on such alternate site suggestions. Applications of the state-owned Power Authority of the State of New York (PASNY), created in 1931, do not have to justify the necessity for the facility as do privately-owned utilities. This distinction is a formal acknowledgement of the historical jurisdictional division between public and private power generating facilities in the state. ${ }^{30}$ PASNY has to follow all the other requirements, and the law requires that the question of need be decided within PASNY by its Board of Trustees.*

One innovative feature allows local governments to be compensated for obtaining expert advice and testimony in the hearing process. The applicant must make available $\$ 25,000$ for this purpose, the unspent portion of which is returned after hearings are completed.

Included in the statute is a requirement for each electric utility in the state to prepare a ten-year plan, updated annually for the number and types

\footnotetext{
Whose members are appointed by the Governor with the advice and consent of the Senate.
} 
of generating facilities it expects to be operating, as well as data on anticipated research expenditures. Approval of this plan also requires public hearings.

New York's power plant siting law presently is scheduled to expire on December 31, 1978, and a legislative review of its impact is anticipated prior to that date as part of the dialogue over its possible extension. Comment on and Criticism of the Act

Since passage of the New York siting statute in 1973, seven applications have been filed for certificates to construct a power plant. As of January 1977, however, none had completed the siting process.

Some of those who felt originally that the act's one-stop permitting procedures would make energy siting easier now wonder whether in fact this has been the case. Critics attribute the slow progress in siting approvals to the comprehensive and detailed requirements of the law and to the presence of very active anti-nuclear groups in the state. 31 In addition, some point to the difference between New York state and federal intervention procedures. They feel that New York's mechanism allows the raising of issues which may not be factual, whereas in federal hearings a more clear technical basis for intervention must be established. 32

Public and Agency Participation. The drafters of New York's siting law took special steps to ensure broad public participation in the decision-making process, not only for siting decisions but even for the 10-year plans submitted by utilities. This provides an opportunity for early public comment on demand forer.asts and related issues, and stands out in contrast with Maryland's law which also requires 10-year plans from utilities, but does not call for any public participation until a utility actually applies for a Certificate of 
Public Convenience and Necessity when it is ready to construct a specific facility. In addition, the New York law, in its hearing procedure and its right to appeal, affords an environmental advocacy rcle for the state agency charged: with environmental protection. (DEC).

Local Laws Superceded. The statute includes an important disclaimer. First, it declares that applicants must be in compliance with state and local environmental and health laws. However, it then demurs on this point by stating:
"except that the board may rafuse to apply any local ordinance, law, resclution or cther action or any regulaticn issued thereunder or any local standard or requirements which would be otherwise applicable if it finds that as applied to the proposed facility such is unreasonably restrictive in view of the existing technology or the needs of or costs to consumers whether located inside or outside of such municipality."

The law thus allows the Board to preempt local laws on the basis of possibly subjective criteria.

Relationship to Other Energy-Related Siting Regulations. The state has no specific siting provisions for other energy facilities, such as refineries, gas separation plants, or cil storage areas (tank farms). This gap may be particularly important in relation to Outer Continental Shelf development. State law does, however, cover gas pipelines.

A major criticism of New York's siting legislation is that it does not unite the certification of electric generating facilities and transmission lines under the same regulatory mechanism. ${ }^{33}$. Since these aspects of utility planning are closely interrelated, it would seem preferable to control them under the same administrative procedure, and to effect this fusion of regulatory authority sooner rather than later.

Establishment of Need for the Facility. Although privately-owned utilities 
must justify the need for the proposed facility, applications of the Power. Authority of the State of New York (PASNY) do not, in an interdisciplinary proceeding, have to prove this point, so basic to overall siting questions.

Review of Nuclear Power Plants. A reading of Section 141 on exemptions from the 1972 statute can be confusing in regard to sitirg of nuclear facilities. This section states that the law shall not apply to:

"a major steam electric generating facility over which any agency or department of the federal government has exclusive jurisdiction, or has jurisdiction concurrent with that of the state and has exercised such jurisdiction, to the exclusion of regulation of the facility by the state."

Nuclear facilities, in fact, are included under the New. York siting law, although considerations of reactor and radiological safety are explicitly preempted by federal jurisdiction. Indeed, of the seven applications currently in the New York siting process, three are for nuclear facilities. 34

Site Acquisition. In 1968, the state's Atomic and Space Development Authority (ASDA) was authorized to take an active part in development and acquisition of nuclear power facilities. ASDA was granted condemnation powers and could acquire property for use in construction of nuclear power plants. 35 Passage of the 1972 siting law, and the shift in emphasis from rellance on nuclear power to development of alternate suurces -- evidenced by formation of NYSERDA in 1975 -- saw the transfer of this siting authority from ASDA to the siting board.

Although the 1972 statute contains no provision for a state site bank as in Maryland, the New York State Power Authority does acquire sites for its own immediate use (as opposed to sité bank1ng for [uluit energy development). 36 
Wetlands, Flood Plains and Coastal Protection Laws

Although New York's 1972 power plant siting law is the definitive document on this subject, the state's Tidal Wetlands Act enacted in 1973 forms an integral part of the overall siting picture. ${ }^{37}$ New York was the last Northeastern coastal state to enact coastal wetlands legislation. Prior to this, the state had little power to protect such lands. As in other states, state review of Army Corps of Engineers dredging notices did provide some control, but this extends only as far as the Corps' jurisdiction, to the mean high water line. 38

In 1972, a Wetlands Act passed by the state legislature was vetoed by Governor Rockefeller on the grounds that it was overly restrictive of state utilities' development. Another bill, drafted to meet the Governor's objections, was enacted by the legislature and signed by the Governor to be effective on September $1,1973 .^{39}$

New York's Wetlands Act is similar to that of other states in that it provides for an inventory of wetlands and regulation of their use. The law authorizes the Commissioner of Environmental Conservation to adopt land use regulations compatible with the public policy of preserving particular wetlands according to their ecclogical value. All regulated activities in the wetlands are prohibited without a state permit. The act upholds the rights of the private owner by providing for compensation when regulations are considered unjust, and in basing subsequent tax assessments on the lise limitations imposed by the regulations. Sirce this statute is administered under the Coastal Zone Management Program, the state is able. to receive matching federal funds. 40

In addition to wetlands protection, in 1974 the New York state legislature 
enacted a Flood Plain Law requiring DEC to assist local governments with flood plain regulation standards under the national flood insurance program. DEC is authorized to impose flood plain controls when lccalities fail to do sc. ${ }^{4}$

A coastal protection law proposed for the state died in legislative committee in the 1973-74 session because it conflicted with the "home rule" desires of towns (as municipalities are called in New York state), some of which already have strong coastal protection legislation of their own. State legislators agreed not to infringe on the policies of the towns. 42

Legislation Specific to Nuclear Facilities

Legislation to provide specific safety assurances and saleguards lui nuclear facilities is pending before the New York legislature. This Nuclear Responsibility Act would limit construction of new nuclear plants until certain specific conditions were met, including testing of emergency systems luside the reactor, provision for assured fuel supplies and for adequate storage and reprocessing facilities for radioactive wastes, publication of detailed evacuation plans, and removal of the liability limit which the federal government has provided the nuclear industry (the Price-Anderson Act). ${ }^{43}$ The substance of these measures is similar to the restrictions enacted by the California legislature (the three Warren bills) just before the more far-reaching voter initiative (Proposition 15) was defeated there on June 8, 1976. Similar legislation has been introduced in New Jersey. The New York bill is considered to have a good chance of passage in the Assembly, although it is opposed in the Senate by Senazor James T. MeFarland of Buffalo, Shairman of the Senate's Corporations, Authorities and Public Utilities Committee. The proposal, however, has the support of the state's Commerce Commissioner as well as local and national environmental groups. 44 
In addition, an amendment to the Public Authorities Law in relation to nuclear power plants was introduced in both houses on February 25, 1976.45 This proposal would not allow nuclear power plants to be operated within a 10n-mile raduis of any city which contains a population of one million or more people. It is a very short bill, which states:

"Notwithstanding the provisions of any law to the contrary, no nuclear power plant may be operated within a one hundred mile radius of any city which contains a population of one million or more. This act shall take effect immediately."

This is essentially a measure for protection of New York City, the only municipality in New York State with a million or more residents. As of late 1976, the bill had not moved out of committee in either the Senate or Assembly. Since it contains no "grandfather clause", the assumption is that -- if the bill were to pass in its current form -- it would require closure of the currently existing nuclear plants at Indian Point in Westchester County, less than 100 miles from New York City. ${ }^{46}$

A similar bill introduced May 11, 1976, would prohibit construction, operation, or an increase in operating capacity of nuclear reactors within any. city having a population of one million or more after the effective date of the law. ${ }^{47}$ The latter proposal has 18 sponsors, in contrast to the previous measure which had only two. It would not require closure of the Indian Point facility, but would prohibit siting of new nuclear reactors within New York City (Con Ed had proposed to locate a nuclear power plant at Ravenswood, Queens in the late 1960 's, a site subsequently rejected in the federal licensing process). This bill is in the Assembly Committee on Corporations, Authorities and Commissions, since it amends the public service law. No action took place prior to adjournment of the legislature at the end of June 1976 . 
Although New York state had over 100 energy bills pending before its legislature in 1975-76, only a very few of these proposals have been enacted in the last two years. This is attributed," in large measure, to a lack of energy policy and guidelines on the state and federal level. In addition, the financial crisis in New York City and in the state has been very demanding of legislators' time and effort.

Two prime accomplishments were the establishment of New York's ERDA in 1975 and its State Energy office in July 1976. A legislative gap still exists in connection with the various proposals for energy conservation which would enable the state to apply for federal funding. This should be facilitated by the new State Energy office, which was granted comprehensive authority in this area. New York also has a policy gap pertaining to siting of energyrelated facilities other than power plants, including those associated with Outer Continental Shelf development.

The complexity of energy issues plays its own part in slow progress, but perhaps a more relevant fact in New York state has been the presence of so many other "squeaky wheels" demanding attention on a priority basis. 
1. Southern Interstate Nuclear Board (SINB), Power Plants in the United States (Atlanta: SINB, September 1974), page 275.

2. Interview by Grace Singer, Princeton University, Centar for Environmental Studies Researcher, with Dr. James Monroe, Executive Director, New York State Commission on Energy. Systems, June 23, 1976.

3. Council of State Governments, "Selected State officials and the Legislatures," Supplement I, The Book of the States - 1975 (Lexington, Ky.: CSG, 1976).

4. Interview by Singer with Lorna R. Bernard, Counsel, Emergency Fuel Office and liaison with the state legislature, May 21, 1976.

5. Ibid.

6. Interview with Monroe, op. cit.

7. \#88, Chapter 864 .

8. A12095-59715-A.

9. Ibid., Section 1.

10. New York Times, Editorial, June 16, 1976.

11. Interview by Singer with William E. Davis, State Energy Office, January 27, 1977. (Mr. Davis was formerly with the New York State Department of Commerce as indicated in footnote 22.)

12. $\mathrm{S}-7836$.

13. Interview by Singer with Dr. Glenn Stevenson, Principal Scientist, New York State Assembly, May 18, 1976.

14. Interview with Davis, op. cit.

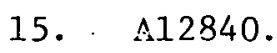

16. Interview with Bernard, op. cit.

17. Chapter 824, June 7, 1974.

18. N.J.P.L. 1975 , c. 217.

19. S7872 - A10104.

20. Comments of the New York State Emergency Fuel office submitted to the Joint Public Hearing of the Senate and Assembly of the State of New York by Lorna R. Bernard, Counse1, May 6, 1.976. 
21. The Siting of Major Electric Generating Facilities Act, New York Public Service Law, s 140 et. seq.

22. Interview by Singer with William A. Davis. Associate Industrial Scientist, Energy Siting Office, New York State Department of Commerce, May 18, 1976.

23. E. Graf-Webster et. al., Mitre Corporation, "Resource and Land Investigations (RALI) Program: Methodologies for Environmental Analysis," Volume III: Poijer Plant Siting, Report prepared for U.S. Geological Survey and distributed by National Technical Information Service, August 1974, p. 74.

24. New York Times, March 2, 1967, p. 1 .

25. Ibid., June 14, 1967, p. 20.

26. Interviev by Singer with Stephen Shuenliulz, Assistant Director of Public Information, Power Authority of the State of New York, June 24, 1976.

27. SINB, Power Plants in the United States, op. cit., 1976 update,

28. Chapter 386 .

29. Interview by Singer with Cloin Robertson, Siting Program Manager, New York State Energy Research and Development Authority, June 23, 1976.

30. Interview by Singer with Kenneth Graham, Information Specialist, Power Authority of the State of New York, January 25, 1977.

31. Interview with Davis, op. cit.

32. Interview with Robertson, op. cit., January $20,1977$.

33. Graf-Webster, op. cit., p. 78 .

34. Interview w1th Davis, up. cit.

35. "Laws and Procedures of Power Plant Siting in New England and New York," Power and the Environment, Report No. 3, New England River Basin Commission, March 1972, p. 7 .

36. Interview with Robertson, op, cit., June 23, 1976.

37. New York Environmental Conservation Law, Sec. 25-0101 - 25-0602.

38. Lorraine Lagna, Marine Sciences Research Center, State University of New York at Stony Brock, The Relationship of Spartina Alterniflora ro Mean High Water, May 1974, F. 87.

39. Ib1d., p. 88 .

40. "A Summary of State Land Use Controls," Land Use Planning Reports, July 1974, p. 38. 
41. Ibid.

42. Interview with Stevenson, op. cit.

43. New York Times, Editoria1, June 15, 1976.

44. Ibid.

45. S8182 - A10276.

46. Interview with Schoenholz, op. cit., June 28, 1976.

47. Al2683. 
PENNSYLVANIA: POLICY LIMITATIONS IN AN ENERGY-PRODUCING STATE

Although Pennsylvania is a complex industrial state which itself produces a greal deal of energy -- the only state in the Northeast to do so -- it has moved very slowly in the area of energy policy, including energy facility siting. These policy limitations seem especially meaningful in view of the existence of a proposal from a consortium of utility companies to construct a large energy cluster ("energy park") within the state.

\section{Legislative Structure for Energy Policy}

Pennsylvania's General Assembly consists of a Senate end House of Representatives. In the Senate, the Environmental Resources Committee receives most energy legislation; proposals for tax exemptions on alternative sources of energy (e.g., solar) and similar matters have been directed to the Finance Committee. The three pertinent committees in the House are Mines and Energy Management, Conservation and Finance. ${ }^{1}$

Conditions in the Pennsylvania House have been described as chaotic at least since 1974. Apparent1y there are three reasons for this. First, the House has an unusually large membership, 209 representatives. 'lhis compares, for example, with 150 in the lower house of New York, and 80 in both California and New Jersey. ${ }^{2}$ Second, according to the rules of the General Assembly, bills can be removed from further consideration at various junctures in the legislative process at the whim of any individual legislator. Third, after bills have remained on the legislative calendar for 15 days, they are automatically removed and must be reintroduced. 3 Those who attempt to follow legislation in Pennsylvania -- including, of course, the legislators themselves -- thus have a very difficult task. 
This unwieldly legislative structure perhaps explains, at least in part, the Pennsylvania legislature's meager record to date on energy policy...

\section{Overal1 Legislative Activity}

In the Council of State Government's March 19.75 compendium of actions taken in various states across the nation following the energy crisis which began with the OPEC oil embargo in October, 1973, the following. five categories were listed:

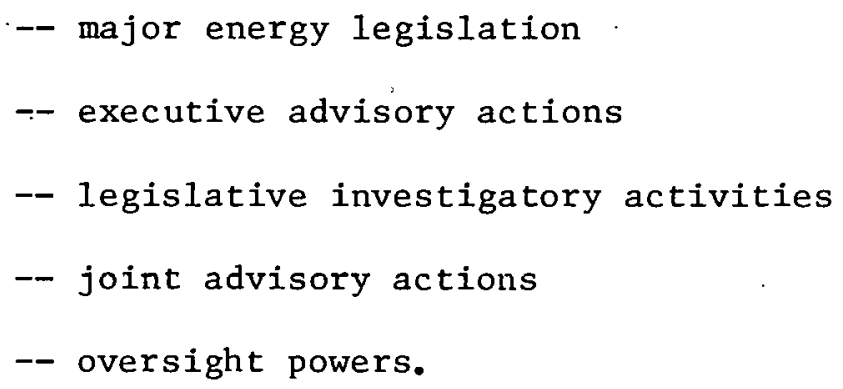

Of all these categories, Pennsylvania's only action was the formation of the Governor's Energy Council, established by executive order of the Governor in February 1974. 4 This was a much more modest. response than was evidenced in the other large states of the Northeast, and one of the . lesser responses nationwide. Although the Energy. Council has issued policy recommendations on energy conservation and coal development, most of these do not appear to have been implemented.

The following pages recount some of the more significant legislative events regarding energy policy in Pennsylvania in the $1975-76$ period.

\section{Energy Facility Siting Activities}

Under current Pennsylvania laws, no state approval is required if a power plant is proposed in an area zoned locally for such use, or if a variance has been granted by the local zoning board. If the proposed site 
is not zoned for such facilities and the local zoning board will not grant a variance, the utility company can apply to the state Public Utility Commission (PUC) for a Certificate of Convenience. The PUC may grant the power of eminent domain to the utility, thereby overriding local zoning laws. 5

In December, 1970, the Department of Environmental Resources was created through consolidating the functions of various existing agencies. This act also established an Environmental Quality Board consisting of existing agency heads, including the Chairman of the Public Utility Commission, public appointees and legislators. The Board has developed a draft environmental master plan for the Commonwealth which incorporates land capability planning. ${ }^{6}$ Policy implementation is expected to commence in 1977. In addition, the Office of State Planning and Development is expected in mid-1977 to issue a state land use plan, the result of a twoyear effort, including one year of public hearings. The plan will have a section on large-scale private or public development, including energy facility siting. Though state guidelines will be issued, decision-making authority will lie with counties who will be responsible for facilities. with impacts beyond the municipal level. 7 Input to the planning agency has been received from the Environmental Quality Board, with the expectation that the plans will complement each other. 8

In a 1974 report, the Governor's Science Advisory Committee outined the Commonwealth's energy priorities in this manner:

\footnotetext{
"There is agreement on the urgency and importance to Pennsylvania of proper development of nuclear power and of the three c's Conservation of energy, Conversion to Coal (in the 70's) and Conversion of Coal to sulfur-free gas and oil (for the $80^{\prime} \mathrm{s}$ ). 9
} 
The report also recommended development of power plant and transmission line siting criteria to apply to the year 2000 and beyond. As of late 1976, however, Pennsylvania's legislature was still struggling with the siting issue.

Proposed Power Facilities Planning and Site Approval Act .

This measure was introduced by Senator Franklin Kury (Democrat, Centre County, which includes Harrisburg) almost 10 years -- 5 legislative sessions -- aga when he was a member of the House. Over the years, different bills on this subject have been proposed, but Senator Kury's bill has emerged as the principal document, with at least a dozen sponsors at various times. The bill, however, has never made it past the committee stage. 10

Until about 1975, legislators' only concern with energy facility siting involved the issue of eminent domain, which generated a good deal of political attention. With the advent of citizen concern over the nuclear energy issue, however, attitudes shifted to focus on other aspects of. siting legislation. ${ }^{11}$ The specific catalyst for renewed interest in power plant siting legislation was the proposal in January 1975 by a consortium of utility companies to build an energy cluster in Pennsylvania (discussed below).

The Kury Bill has been under consideration by the Senate Environmental Resources Committee since at least February, 1975, but no hearings had been scheduled as of early 1977. Senator Kury, along with other legislators, was a candidate for re-election in 1976, and had asked that the bill be tabled. ${ }^{12}$ In addition, legislation passed in June 1976 commends 
the energy facility siting issue for study to the Joint State Government Commission.* Until this commission makes its recommendations, the bill would remain in limbo, and chances of passage even in the, 1977 legislative session are not considered good. ${ }^{13}$

Principal Features of the Bill. Although the Pennsylvania Power Facilities Planning and Site Approval Act makes no commitment to state site selection, acquisition or evaluation, as does the 1971 Maryland law, it does have another feature in common with Maryland's legislation: a surcharge on utilities operating in the state to provide revenue for administering and enforcing the provisions of the law.**

In its declaration of purpose, the bill states: "Primary consideration shall be given to the conservation and protection of the environment." To carry out this mandate, the bill would grant the Department of Environmental Resources (DER) final authority to issue (or deny) Certificates of Site and Facility for approved power plant construction applications. Under the Act, DER would be required to:

-prepare and maintain 10-year plans, based on comprehensive data from utilities, regarding all power plant facilities and the need for coordination with other utilities to meet the overall energy requirements of the region. This information must also include analysis of any facility's anticipated impact on the environment, public safety and health, and a description of the utility's plans for avoiding or minimizing any adverse effects;

-review and make public the information contained in the longrange plans, including an annual compilation of proposed power plant sites with general locations of transmission line routes and anticipated construction dates;

\footnotetext{
*Discussed on p. 121 . **

The surcharge is not to exceed the rate of .01 mil per kilowatt hour generated (vs. Maryland's .03 mil ceiling). Another difference between the Pennsylvania and Maryland surcharge is that Maryland specifically allows it to be charged by the utilities to its customers, and Pennsylvania makes no such provision. This difference may be academic since the cost seems certain to be passed along to the consumer, although not as a specific line item on bills as is the case in Maryland.
} 
-conduct mandatory public hearings on any proposed power plant sites, which must be identified five years in advance of construction, and decide whether or not such sites should be approved for inclusion in the utility's five-year inventory of sites;

-conduct public hearings in locations "as near as feasible to the proposed site" prior to issuance of any certificate for a power plant;

-conduct inspections, surveys, monitoring or testing with or without notice to the utility, as DER deems necessary;

-submit all plans, applications and notices of hearings to the PUC. No DER certificate may be issued until the PUC has been given a period of at least 30 days in which to review the application and render its advice and comment.

DER may not issue certificates until it makes certain positive findings, including that:

-use of the proposed site is consonant with the protection of the environment, public safety and health;

-the proposed facility is necessary to meet the electric power needs of the state;

-all practical alternative sites have been considered;

-measures have been taken by the applicant to conserve energy use.

Duties to be delegated to the Environmental Quality Board (which includes the Chairman of the PUC) under the proposed act include adoption of rules and regulations to implement the purposes of the act, and approval of the long-range plans prepared and recommended by DER for selection of power plant sites and transmission line corridors. Reinforcing current regulations, the proposed act provides powers of eminent domain to utilities on all land approved by DER, and allows pre-emption of local approvals or permits where necessary.

Comment on this Proposed Siting Legislation. While this bill would be a progressive departure from the current lack of state control over 
energy facility siting in Pennsylvania, it would still place the state in a reactive position on site plans, all of which would still be initiated by the utilities. The state still would not determine, on the basis of overall land use policy, where power plants might best be located. Authority would exist to decide where such facilities may not be placed, after sites had been proposed by utilities. The proposed act would incorporate early public and agency contributions into the dialogue on which final siting decisions would be based.

The Energy Cluster Proposal

In January, 1975, a proposal to develop an energy cluster in Pennsylvania was referred to the leglslature. This proposal, which by then had received a great deal of public attention, emanated from a consortium of utility companies operating under the name "Energy Park Development Group". Four corporate entities were included: Metropolitan Edison Co., Pennsylvania Electric Co., Pennsylvania Power \& Light Co., and Philadelphia Electric Co. Basically, the proposal called for development of an "energy park" of up to 20 power plants, for a total of 10,000 to 20,000 megawatts of generating capacity. Discussions of the proposal varied as to whether the cluster would contain only nuclear, only coal, or a mix of the two facilities. The formal proposal document considers "a mix of coal and nuclear, with a potential of standardization of each of the two types". 14

The principal conclusions and recommendations of the utiliey consortium which made this energy cluster proposal were as follows:

"Major Roadblocks to Be Resolved

-Satisfaction of regulatory and judicial authorities and public opinion leaders that the net adverse environmental impact of energy parks is less than the nct adversc cnvironmental impact of an equivalent amount of generation located on numerous scattered sites. 
-The earliest feasible date for the first unit in an energy park, taking into account minimum 'front end' times for a new concept, is 1985 if the first unit is fossil and 1987 if the first unit is nuclear.

Major Advantages of This Concept

-Optimization of site selection and licensing effort.

-Standardization of engineering and construction, leading to

lower costs and higher productivity.

-Efficient utilization of support services.

Major Problems to be Overcome

-Lack of sufficient cooling water to support the intended amount of generation.

-Unacceptable combined environmental effects of all the plants, such as waste products, gaseous and vapor emissions, aesthetics, etc.

-Aesthetics and cost of transmission requirement.

Pitfalls to be Avoided if Further Development of Energy Parks is Pursued

-Underestimation of the monumental size of the complex, particularly in terms of significant impacts on the natural environment; significant impact on the human environment; acquisition, maintenance and management of a stable construction force; acquisition of necessary waste product disposal area.

-Overestimation of the ability to gain public acceptance of the concept.

-Failure to bring federal and state agencies on board in the initial planning phases of the project.

-Financial inability to carry cost overruns." 15

In a July, 1975 report from Pennsylvania State University, Energy

Parks and the Commonwealth of Pennsylvania, the following principal con-

clusions were reached:

-"The energy park siting alternative is not likely to significantly reduce the consumer's kilowatt-hour cost of electricity.

-Including land devoted to additional transmission line rights-ofway, the park alternative may require additional land comitments to power generation. 
-The environmental consequences of a park do not differ qualitatively from the dispersed alternative, although such effects will be more intense at the site.

-The park's local socio-economic impact is anticipated to be less serious than forecasted by previous studies within the Commonwealth.

-The dissipation of reject heat from the park's generating units will place substantial demands on the involved watershed.

-No final assessment of the park concept or its various characteristics is possible without specific sites considered relative to dispersed siting alternatives.

-Work should be initiated to develop the necessary data and knowledge concerning the impact of energy center complexes.

-A reassessment should be made of the ability of existing state agency structures to respond to intra- and inter-state concerns on energy facility siting .... in particular, encouragement is given for a study to assess the applicability and transferability of Maryland's power plant siting process to the state of Pennsylvania."16

On Ju1y 16, 1975, the Energy Park Regulation Act was introduced in the Pennsylvania legislature. ${ }^{17}$ This bill would give local government explicit veto power over such facilities, rather than giving override authority to the PUC as is currently the case. This act would require any bulk power supply facility designed for an ultimate capacity of 5,000 megawatts or greater to obtain explicit local approval prior to a utility's acquisition of 1 and and/or construction for this purpose. This act, too, died in committee:

In a January 23, 1976 press release, the Energy Park Development Group (the utility consortium) announced deferral of further study of the cluster concept pending government resolution of several basic energy policies, specifically:

-an organized approach for siting power plants;

-encouragement of the use of coal; and 
-direct realty tax benefits to communities where power plants. are located* 18

The consortium urged favorable action on these issues, and stated:

"power plant sites must be considered within the broad context of a land use policy for the Conmonwealth. Without such a policy there is no way to resolve the many conflicting interests concerned with the siting question."

In addition to the reasons cited above, many observers believe that strong opposition from environmental groups and residents in the areas tentatively selected for the energy cluster were also responsible for the utilities' decision to defer further action on their cluster concept. ${ }^{19}$

Although the Energy Park Regulation Act proposed in 1975 was never passed by the legislature, continuing concern over the energy cluster issue and over the basic role of local governments in energy facility siting led to approval by both houses in June, 1976, of a legislative resolution directing the Joint State Government Commission to organize a Task Force to study the overall issue of energy facility siting. This Commission is a "nonpartisan and independent" body with a permanent staff which works with the legislature. 20 The resolution sets forth the following rationale for such a study:
"The concept of 'energy parks' for Pennsylvania has been under study of the Governor's Energy Council for the past year and, in that time, a number of basic issues have been identified, including the role of local government in power plant siting, the impact of amendments. to the federal Clean Air Act on the further development of coal-fired generating facilities, a recent Nuclear Regulatory Commission survey on the siting of nuclear 'energy parks', local incentives in the utility taxation field and state development in nuclear siting; and...
After a year's study which included consultant assistance in deter- mining socio-economic-environmental impact of 'energy parks', these

\footnotetext{
* Real estate taxes on power plants in Pennsylvanis are paid directly to the state. Local government leaders have complained that the rebate from Harrisburg does not compensate them properly for having a plant in their area.
} 
issues have yet to be definitely resolved despite a number of public hearings throughout the Commonwealth; and...

The Council itself has recommended that, pending resolution of these and other basic issues, further movement on the 'energy park' issue be deferred pending a full and thorough review by the General Assembly; and...

The General Assembly recognizes on one hand the need for additional electrical generation and on the other hand the legitimate concern of local government officials and local citizens.for the disruption of local life-style associated with plant construction, the lack of local tax benefits, local environmental impact and related legal and economic questions, all of which must be addressed.21

In addition to conducting an "independent" study of all the ramifications of energy facility siting, the Commission must specifically ponder the role of local governments in power plant site selection and the apparent 1ack of adequate local tax benefits to compensate for the costs of accomodating such facilities in the local area. Within nine months -- or in March, 1977 -- the Commission is to report the findings of its study to the General Assembly, along with appropriate drafts of any recommended legislation.

\section{Strip Mining Legislation}

Pennsylvania has large coal deposits, and one of the most stringent strip mining laws in the country. A permit and operator's license are required for each strip mining operation, and these are issued only after a reclamation plan has been approved and a sizeable performance bond posted. An operator must also obtain a water quality permit, and the bond covers water quality considerations as well. Reclamation requires return to original contour in certain instances, and must be almost concurrent with mining. Topsoil must be saved and replaced. In 1972, Pennsylvania issued 3,400 non-compliance citations under its strip mining law, highest by far in the nation; the next state in such performance was Kentucky, which issued 480 citations. 22 
In response to proposals to drill for natural gas in Lake Erie, a bill was introduced in the House in 1976 to prohibit drilling for oil and gas in the lake. ${ }^{23}$ The expressed concern in the House dealt with the danger of oil spills. The Governor's Energy Council considers this fear to be unfounded, since there is apparently no oil in Lake Erie; the Council takes the position that drilling for natural gas should go forward. Election year concerns also may have played a part in the legislators' consideration. The measure passed in the Pennsylvania House in June 1976, and was expected to be revived in the Senate Environmental Resources Committee in the fall when the legislature reconvened。 ${ }^{24}$ As of January 1977 the legislation was still in the Senate Committee. ${ }^{25}$ However, at the same time the Pennsylvania House of Representatives took this action, the Senate in neighboring New York State acted in an opposite manner to permit drilling for gas (though not oil) in Lake Erie. Canada allows such drilling on its side of Lake Erie, and currently has 300 active wells there.*

In another manner, Representative Bernard O'Brien (Democrat, Luzerne County), Chairman of the Mines and Energy Management Committee, sponsored a bill to place a moratorium on federal Clear Air Act standards for Pennsylvania in order to promote the use of coal. ${ }^{26}$ According to the legislative rationale, this moratorium would remain in effect until more is known about pollutants and better control equipment is available. The clear intent of this bill was to "shake up" the Department of Environmental Resources and make it more responsive to the economic issues involved. The bill is in Representative O'Brien's committee, where action might progress in the 1977 session. 27

See pp. 113-115. 
In the area of solar energy, legislative events in 1976 illustrate the difficulty often faced in getting legislation through Pennsylvania's House of Representatives. A bill to exempt solar energy mechanisms from state sales and use taxes was passed in the Senate by a vote of 44 to 3 ; $^{28}$ it was then referred to the House Finance Committee, which tabled the measure. Public hearings were to held on this issue during the summer, after the legislature adjourned; and national solar energy experts were asked by the Governor's Energy Council to testify at this hearing. As of 1977 , the issue was still pending in the House committee.

\section{Conclusions}

In the area of energy legislation, Pennsylvania seems to have moved very slowly as a result of two fundamental problems. First, itc legialative structure, particularly in the large House of Representatives, is unwieldy and cumbersome. This makes it difficult to facilitate legislation in an orderly fashion, especially on a complex subject like energy. Second, the Pennsylvanla legislature appears to be operating in a policy vacuum where land use, energy facility siting and other energy policies are rnncerned, although recommendatinns on conocrvation alul cual development have been issued by the Governor's Energy Council. A restructuring of the state'e legislative procedures and strong leadership might both be necessary if adequate energy measures are to progress.

In addition, the lack of a state siting statute leaves in force the existing procedures whereby a utility company can pruceed without state review if it obtains local approval, and can receive relief from the state PUC if it does not receive such local approval. This over-ride mechanism 
does not have the protection of detailed state site evaluation established in other states, such as neighboring Maryland. Even the major siting statute proposed in the Senate is limited in that regard, but it would certainly be a vast improvement over Pennsylvania's (non-) existing laws where energy facility siting is concerned.

Pennsylvania, as a highly-industrialized state, would seem ill-able to afford lack of progress on energy facility siting. The proposal for a large energy cluster within the state lends added urgency to the siting issue, and points clearly to the need for new statutory mechanisms. 
1. Interview by Grace Singer, Princeton University, Center for Environmental Studies Researcher, with Dennis Seipp, Governor's Energy Council - Legislative Liaison and Coal Coordinator, May 17, 1976.

2. Council of State Governments, "Selected State Officials and the Legislature", Supplement I, The Book of the States: 1975 (Lexington, Ky.: CSG, 1975), pp. 14, 113, 119 .

3. Interview with Seipp, op. cit.

4. Council of State Governments, State Responses to the Energy Crisis (Lexington, Ky.: CSG, March 1975), pp. 28-30.

5. Southern Interstate Nuclear Board, Power Plant Siting in the United States, September 1974 , p. 337 (1976 update)

6. Ibid.; and American Bar Association, Industrial Site Selection at the State Level, Draft Report, 1974, pp. $\overline{3-7}$ and 3-8.

7. Interview by Singer with Mark McClellan, Administrative Analyst, Office of State Planning and Development, January 27, 1977.

8. Interview by Singer with Eugene Eisenbise, Director of Planning, Environmental Quality Board, January 26, 1977.

9. The Governor's Science Advisory Committee, Energy for Pennsy1vania A Plan for Action (Harrisburg, Pa.: April 1974), p. ii.

10. Interview with Seipp, op. cit.; Senator Kury's bill in 1976 carried the designation S-293.

11. Ibid.

12. Ibid.

13. Ibid.

14. Energy Park Development Group, Energy Parks in Pennsylvania: Where, When and How, March 1974, Revised January 1975, p. 9.

15. Ib1d., pp. 3-5.

16. The Center for the Study of Environmental Policy, Pennsylvania State Univcroity, Encrgy Parks and the Commonwealth of Pennsyluani.a - Tsanes and Recommendations, Volume I: Summary (University Park, Pa.: PSU, July 1975), pp. 1, 2, 38 .

17. $\mathrm{s}-960$.

18. Press Release from the Energy Park Development Group, January 23, 1976. 
19. Interview by Singer with William Prindle, Delaware Valley Regional Plan Association, Environmental Planning Division, May 12, 1976.

20. Interview with Seipp, op. cit.

21. SCR-238, introduced March 30, 1976, approved June 28, 1976.

22. "A Summary of State Land Use Controls", Land Use Planning Reports, Ju1y 1974 , p. 45 。

23. $\mathrm{H}-1658$.

24. Interview with Seipp, op. cit., June 25, 1976.

25. Interview by Singer with Connie Bollase, assistant to Research Director; Joint State Government Commission, January 25, 1977.

26. $\mathrm{H}-1896$

27. Interview with Seipp, op. cit., June 25, 1976.

28. S-979. 


\section{DELAWARE: CONCERN OVER COASTAL PROTECTION}

Delaware i.s dominated by its relationship to the sea. No part of the state is more than approximately 8 miles from the tidewater, and the state's shoreline stretches 160 miles in length around a land area of only 1,983 square miles. The influence of the state's bays, beaches and rivers is particularly compelling in light of Delaware's lack of other significant topographic features or mineral resources. ${ }^{1}$ As a result of this gecgraphical happenstance, and because of pressures for development in the coastal area -particularly new energy tacilities -- Delaware in $19 / 1$ enacted a unique and stringent coastal zone statute prohibiting heavy industry, including energy facilities, from lccating in this arsa. Currently, the state has no other laws on energy facility siting, and its stance on energy policy in general might best be described as "low profile."

\section{Legislative Structure for Energy Policy}

The legislature has six-month sessions annually, from January through June. Although each house of Delaware's General Assembly has standing energy committees -- the Energy Committee in the Senate and the Natural Resources and Energy Committee in the House of Representatives -- there is no professional staff advising legislators on energy issues, and no research capability is currently available. ${ }^{2}$

The leadership in the House tends to direct legislation to the appropriate subject committee. In the Senate, however, subject matter is not always the principal criterion for such decisions; legislation may be placed in other committees based on political or personal considerations. Most legislative initiatives on energy have taken place in the House, apparently because the 
Senate is a more conservative body less imbued with activism.

As in most states, an initial flurry of activity followed the energy crisis of 1973-74. A grant of emergency powers was made to the Governor, and a Joint Energy Investigative Committee was formed to deal with the specifics of fuel shortages prevalent at that time. ${ }^{3}$ This Comittee has issued no reports, and as of 1976 it is completely. inactive.

In addition, the legislature created a Division of Emergency Planning and Operations in the Department of Public Safety. Until August 1976 this was Delaware's energy office, essentially a fuel allocation operation. This unit has a lone staff member, and too has issued no reports or publications. 4. Some of the conservation measures effectuated after the energy crisis included lowering thermostats in state buildings and granting. an extra holiday to state employees after Thanksgiving Day. ${ }^{5}$ An administrative reorganization was seriously considered by the legislature whereby several state agencies, including a more comprehensive Energy office, would be brought under the jurisdiction of the State Planning office. 6

In Delaware, as in many other states, initial interest and activity on energy policy was followed by a relaxation of effort as available fuel supplies returned to normal. An added factor in the state in 1976 was a crisis precipitated by the bankruptcy of a state-subsidized bank which had the full faith and credit of the state behind it. The political repercussions of this incident preoccupied legislators for many months, to the exclusion of other issues, including energy planning. ${ }^{7}$ Most legislative proposals on energy have been in the area of rate structure, primarily in response to sharply increasing costs. Although some of these measures have been enacted, the majority have not been successful, in part due to effective utility 
lobbying efforts. 8

The Coastal Zone Act and Energy Facility Siting

Delaware's Coastal Zone Act (CZA), passed in $1971,{ }^{9}$ is by far the most important document in the state with regard to energy facility siting, primarily because of its stringency and the state's predominant coastal geography. The act makes Delaware the only state completely banning new heavy industry and port facilities - including energy development - within two miles of its coast. 10 Background

On June 28, 1971, then-Governor Russel1 Peterson signed the CZA into law. Ry passage of this act, the state legislature was responding to the recommendations of a special Task Force on Marine and Coastal. Affairs appointed by the Governor in early 1970 to study the problems associated with coastal zone management. ${ }^{11}$

Other factors gave added impetus to the legislature's action. Governor Peterson's'strong backing of the act was important, as was the threat of imminent development of two major energy facilities: (1) a large oil refinery proposed by She11 oil Company at Deakneyville, Del.; ${ }^{12}$ and (2) a deepwater terminal for super-tankers proposed by Zapata-Norris, Inc. at an artifical island in the mouth of the Misplllion River in Delaware Bay, to be used as a storage area for oil and for shipments of coal too large to be facilitated by existing port accommodations.

These two proposals raised fears that the Delaware coastal zone would be turned into a petrochemical center, spreading the existing chemical complex in the Wilmington area (where the DuPont Company has its headquarters) to

* Contrary to popular thought outside Delaware, it is not a universally accepted fact in the state that Governor Petersion was defeated for re-election because. of his strong support for the Coastal Zone Act. Other reasons are considered by some to be the principal causes: e.g., Peterson's reorganization of state government and some unpopular official appointments made by him. 
undeveloped areas along the coast. Others were concerned by the fact that Delaware, as a small state, does not have vast areas to dilute the environmental and land use impacts of concentrated heavy industry in its sensitive coastal zone. In addition, there was support for CZA by those people in Delaware who value fishing, duck hunting and other recreational amenities offered in their coastal area. ${ }^{15}$ The lack of a state policy toward industrial growth in the coastal zone and the absence of regulatory authority over such development left the state in a vulnerable position in relation to pressure for development. This was recognized and dealt with in the 1971 CZA.

In June 19.70, prior to passage of CZA, the legislature enacted a year's moratorium on development in the state's coastal area to allow time for the Governor's Task Force to develop its recommendations for wise use of this critical area. ${ }^{16}$ The preliminary report of the Task Force, completed in February, 1971, recommended encouragement of new industries wich were compatible with high environmental standards and which would employ a relatively high ratio of employees in relation to the space occupied and the public services required, but also recommended that no further incompatible industries be allowed in the ccastal zone. Incompatibility was to be determined on the basis of quantities and types of pollutants emitted and the magnitude of the environmental impacts resulting from the size and nature of the industry. The Task Force also recommended prohibiting a deepwater port facility in Delaware Bay. The report emphasized the recreational values of the coastal zone for the people of Delaware and for visitors from more heavily urbanized neighboring states. 17

Principal Features of the Coastal Zone Act

In its statement of purpose, the statute proclaimed: 
"It is hereby determined that the coastai areas of Delaware are the most critical areas for the future of the state in terms of the quality of life in the state. It is, therefore, the declared public policy of the State of Delaware to control the location, extent and type of industrial development in Delaware's coastal areas. In so doing, the state can better protect the natural environment of its bay and ccastal areas and safeguard their use primarily for recreation and tourism. Specifically, this chapter seeks to prohibit entirely the construction of new heavy industry in its coastal area, which industry is determined to be incompatible with the protection of that natural environment in this area. While it is the declared public policy of the state to encourage the introduction of new industry into Delaware, the protection of the environment, natural beauty and recreation potential of the state is also of great concern. In order to strike the correct balance between these two policies, careful planning based on a thorough understanding of Delaware's potential and her needs is required. Therefore, control of industrial development other than that nf heavy induotry in the Coistis Zone of Delaware chrough a permit system at the state level is called for. It is further determined that off-shore bulk product transfer facilities represent a significant danger of pollution to the Coastall Zune dud generace pressure for the construction of industrial plante in the Coastal Zone, which construction is declared to be against public policy. For these reasons, prohibition against bulk product transfer facilities in the Coastal Zone is deemed imperative."

In its section on definitions, the following important meanings were established:

"The Coastal Zone is defined as all that area of the state...between the territorial limits of Delaware in the Delaware River, Delaware Bay and Atlantic Ocean, and a line formed by certain Delaware highways and roads...

Heavy industry use means a use characteristically involving more than twenty acres and...employing some but not necessarily a.1., equipment cucl: as, but not limited to, smoke stacks, tanks, distillation or recrentinn ulumlls, chemical processing equipment, scribbing towers, pickling equipment, and waste treatment lagoons; which industry, although conceivably operable without polluting the environment, has the potential to pollute when equipment malfunctions or human error occurs. Fxamples of heavy industry are oil refineries, basic steel manufacturing plants, basic cellulssic pulp-paper mills, and chemical plants such as petrochemical complexes. Generic examples of uses not included in the definition of 'heavy industry' are such uses as garment factories, automobile assembly plants and jewelry and leather goode manufacturing establishuents...

Bulk product transfer facility means any port or dock facility, whether an artificial island or attached to shore by any means, for the transfer of bulk quantities of any substance from vessel to onmshore facility or vice versa."

The borders of Delaware's coastal zone for regulatory purposes are shown in 
Figure 2 ; Figure 3 shows the locations of some principal industrial facilities within this area.

All new heavy industry and "off-shore gas, liquid or solid bulk product transfer facilities" are "absolutely prohibited" in the coastal zone. New manufacturing is allowed by permit only, provided that no permit may be granted unless the county or municipality having jurisdiction has first approved the use in question by zoning procedures provided by law. In passing on permit requests, the State $\mathrm{P} 1$ anner and the State Coastal Zone Industrial Control Board must consider several factors:

- environmental impact;

- economic effects;

- aesthetics;

- number and type of supporting facilities required and their impacts;

- effect on neighboring land uses, including recreational, residential and agricultural areas; and

- relevance to county and municipal comprehensive plans for development and/or conservation of their areas of jurisdiction.

The State Planning office administers the CZA, and the State planner is required to provide the Board with proposals for a comprehensive plan relating to allowed uses in the area. After a required public hearing, the Board may alter regulations proposed by the State Planner, as long as decisions are consistent with the intent of the law. The State Planner receives all permit applications and places them in three categories:

-heavy industry, prohibited entirely;

-a use allowable under CZA permit procedures; or

-a use requiring no action under CZA. 


\section{EXISTING INDUSTRIAL OWNERSHIP}

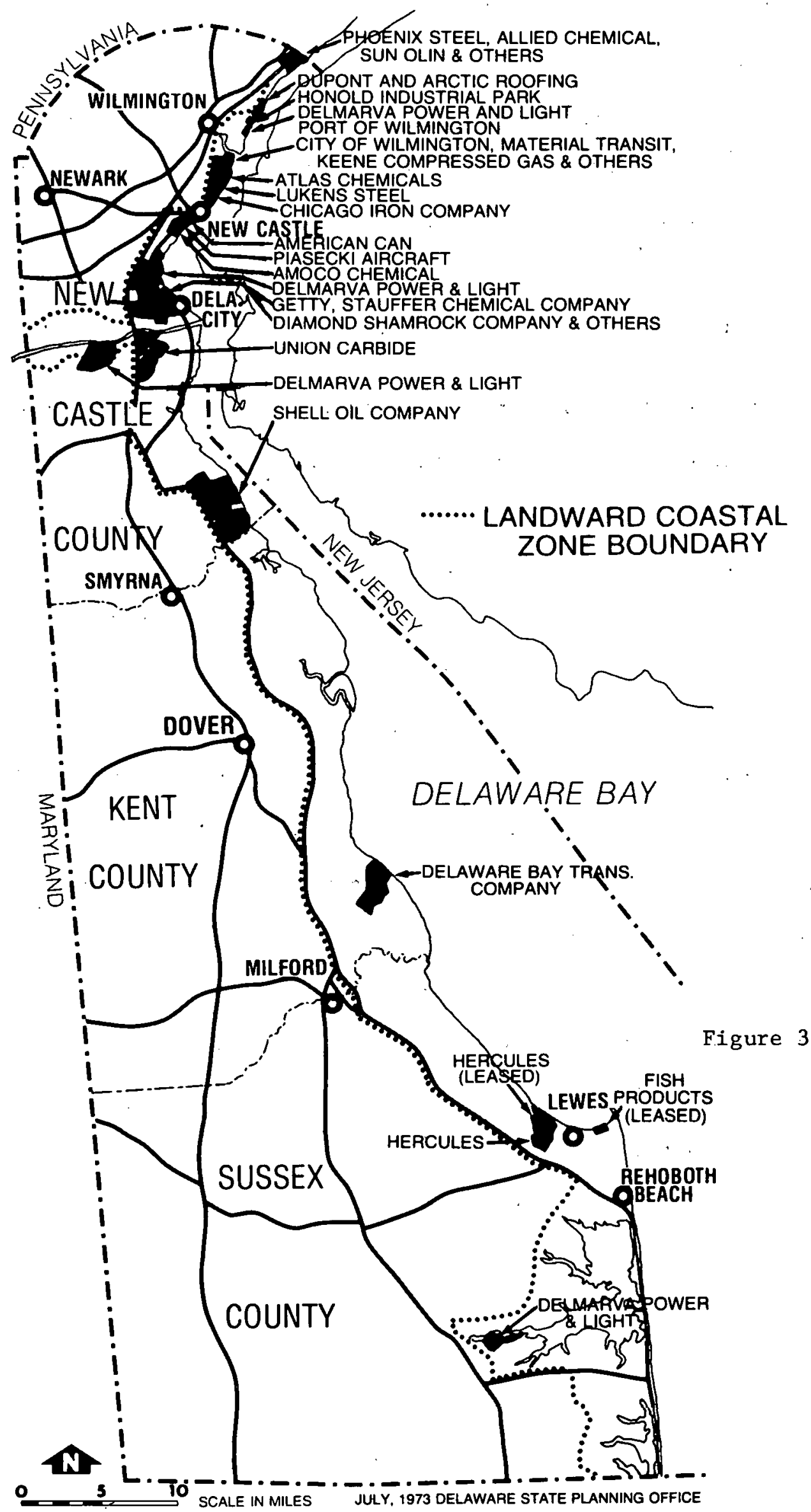


After a public hearing, the State Planner renders a decision, which may be appealed to the Board.

The Coastal Zone Industrial Control Board has 10 regular members:

- the Secretary of Natural Resources and Environmental Contro1;

- the Secretary of Community Affairs and Economic Development;

- the Directors of the Planning Commissions of each of the state's three counties;

- five persons appointed by the Governor and confirmed by the Senate, three of whom to represent the three counties (all five are exofficio voting members).

The Board has authority to hear appeals from decisions of the State Planner on coastal zone permits and may, after a public hearing, affirm, reverse or modify the decision with respect to applicability of a proposed use. The Board may not, however, grant a permit for uses prohibited under the act. Any party aggrieved by a final order of the Board, including the State Planner, may appeal to Superior Court in the county of the proposed facility. If the Court rules that a permit's denial or restriction constitutes an unconstitutional taking without just compensation, the Secretary of Natural Resources and Environmental Control may, through negotiations or condemnation proceedings, acquire the "fee simple or any lesser interests in the land." This authority must be exercised within five years from the date of the Court's ruling; after that period, the permit must be granted as applied for if the land has not been acquired under this provision. The act does not affect local zoning laws consistent with its intent. CZA provides for violation penalties of up to $\$ 50,000$ for each offense, with earh day nf violation constituting a separate offense. 
In the four-year period from June 28, 1971, when CZA berame law to June 30, 1975, 71 project applications were received by the State Plannjng office. In 37 of these cases it was determined that no permit was required under C.ZA; some of these applicants were seeking to install pollution abatement equipment. The next largest group of projects (16) were those which were not processed for one reason or another; e.g. no formal permit application was received.

Fj.ve proposed projects were denied CZA permits. Four of these denials were for energy-related entities, all bulk product transfer facilities specifically prohibited by CZA. These projects included:

(1) A facility to enable supertankers. of 250,000 deadweight tons to moor and unload crude oil for movement by pipeline from a tank farm at Rehoboth Beach to oil refineries in the Delaware Valley. ${ }^{18}$

(2) A liquifjed natural gas (LNG) terminal in New Jersey opposite Claymont, Delaware, involving a pier extending into Delaware waters beyond mean low water on the New Jersey side of the Delaware River. (The company abandoned the project a few days prior to the Delaware State Planner's decision to deny it a CZA permit.) 19

(3) Extension of a pier to be used for unloading crude oil and other petroleum products. 20

(4) A floating mono-buoy barge to off-load fuel at Pickering Beach into a pipeline connected directly to Dover Air Force Base's fuel supply facility. 21

Of the 13 CZA permits granted during this permit, 11 were for non-energy industrial entities ( 6 for expansion of existing plants, primari].y chemical facilities, and 5 for new manufacturing plants). The two energy facility permits 
granted were both to Delmarva Power and Light Company. One was for expansion of Delmarva's existing Edgemoor Power Plant, adding a new boiler to approximately double its power generating capacity. Three residents of Edgemoor appealed this decision to the Coastal Zone Industrial Control Board, which affirmed the State Planner's approval decision, and further to Superior Court which sustained the Board's decision.

Delmarva's other C.ZA application was for a new facility, the Summit Nuclear Generating Station. 22 Following is an account of that project's permit:

"The Company proposed to construct a nuclear power plant south of the Chesapeake and Delaware Canal near the village of Summit Bridge. The main part of the power plant - the reactors and turbines - would be situated outside of the coastal zone, but the cooling water intake structure and intake and blowdown pipelines would be within the coastal zone.

The State Planner and Company agreed that the power plant would not be a heavy industry use. The status decision was that a permit for new manufacturing would be required for that part of the plant within the coastal zone. The Company attorney claimed that no permit should be required because that part of the power plant under the jurisdiction of the Coastal Zone Act is not a manufacturing use by itself.

After an appeal public hearing on May 23, 1974, the Board derjided on July 3, 1974, to affj.rm the State Planner's decision. Subsequently, Delmarva Power and Light did apply for and received a coastal zone permit." (A public hcaring was held on November 18, 1974. No appeals were filed on the project, and a coastal zone permit was issued on Juluury 3, 1975):

However, plans to construct Delmarva's nuclear plant at Summit were withdrawn due to lack of financing and the company's excess capacity at other facilities. Primarily because of this withdrawal, legislation introduced in the state legislature in June, 1975 to postpone construction of nuclear power plants temporar1ly was not enacted, since none were under construction.

The Future of CZA

A number of proposals to amend or repeal CZA have been introduced in the past few years, a1though none have been enacted. In 1975, CZA came under 
severe attack from labor unions and the state Chamber of Commerce, which contended that the law gave Delaware a poor business image. 24

CZA may, however, be superseded in the near future by a comprehensive statewide land use planning act. Such a plan is being proposed by the "Delaware Tomorrow Commission," which was created by an executive order of Governor Tribbitt in June, 1974, and charged with the responsibility to develop "a statewide plan for growth." The commission is composed of 31 members from business, labor, farm, public interest and civic groups (including environmental organizations), as well as representatives from the legislature and state, county and local governmental agencies. The Commission held public hearings and submitted its final report to the governor in January, 1976. Its reference to CZA was as follows:

"Under the Federal Constitution, the States have the responsibility for land use regulation. In Delaware, as in most other states, most of that responsibility has legislatively been delegated to counties and municipalities. One of the questions being raised now is that since the State government provides financing for roads, schools, sewage disposal and other facilities, the demand for which is largely regulated by local government land development decisions, should the State government take back some or all of the land use regulatory responsibility it has historically delegated.

The first significant attempt by the State government to take back land use control was the Coastal Zone Act of 1971. That Act generated much debate by the Commission, primarily around the question of whether the Act itself, or perceptions about the Act, contributes negatively to the industrial development potential of Delaware.

Recommendation: The Commission concluded that the time has come to replace the initial. Coastal Zone Act with a comprehensive statewide planning act. The present regulations should be used intact as interim guidelines to govern industrial development in the coastal zone until the new land use management plan and regulations are complete and enacted. At that time, the comprehensive statewide land use management plan would supersede the current Coastal Zone Act and cther land use control legislation presently administered by the state. 25

In addition, the Commission's report made findings and recommendations on offshore oil and gas development: 
"Deepwater terminals and offshore drilling may develop along the East Coast. Delaware should be alert to and involved in such developments, both to reap the benefits of the job and revenue opportunities and to maintain control to avoid undesirable environmental and other effects.

Delaware's location in the eastern transportation corridors, our coastal rescurces that could be vital to Federal energy policy and our small area that limits growth-generation within our borders, make the State quite sensitive to external forces. If offshore drilling reaches peak production by 1985 and has a full impact in Delaware (in addition to New Jersey, Maryland and Virginia), the State's direct job opportunities in support of oil exploration and extraction could increase by some undefined increment, possibly in the thousands. These basic jobs might add three times as many more service jobs. At the other extreme, if production is small and/or a.ll or most of the impact acliues lo other coastal states, as it may, the effect on Delaware from offshore drilling could be minimal.

The Commission did not have the data required to predict such impact. Delaware awaits the findings of study on this subject by the Congressional office of Technology Assessment (OTA), supplemented by consulting services that Delaware may employ. The State Planning office, under the Coastal Zone Management Program, should do research to predict and eventually direct the landside impact of offshore drilling for oil and gas and/or a deepwater port. To offset the substantial fiscal deficits and employment/income/tax revenue fluctuations likely from such landside impact, the State must attempt to build into other sectors of our economy all the strength, diversity and stability possible.

Recommendation: The State should establish a program to participate in the Atlantic offshore drilling for oil and should study the development of deepwater terminals in such a way as to maximize the future economic benefits while minimizing any detrimental impact." 26

In May, 1976, a draft Land Use Planning Art was fnrmulated by tho statc Planning Office in concert with some members of the Delaware Tomorrow Commission and representatives of local government, and transmitted to the Governor. 27 The Commission met on June 7 and issued a press release stating that the legislation was too complex to be dealt with before the end of the legislative session which adjourned on . Tune $30 t h .^{28}$ The propooed atatute was to be studied over the summer by several members of the commission, who were to report their findings to the full Commission, after which public hearings 
would be scheduled. Specific reference to the coastal zane in the proposed law, which is an amendment to existing state planning statutes, is in its Critical Area Designation (Section 9142), where three categories are designated:

(a) Preservation Zones: acquifers, wetlands, prime farmland, prime forestland, beaches, areas containing or having a significant impact upon historical, natural, or environmental resources of regional. or statewide importance;

(b) The Coastal Zone;

(c) An area significantly affected by or having an effect upon an existing or proposed major public facility or other areas of major public investment.

The State Planning office would be authorized to designate these critiral areas and to create mechanisms by which thejr.r land use can be best controlled. Basically, the proposed legislation embodies the intent of the Delaware Tomorrow Commission's recommendations regarding statewide minimum standards in land planning and critical area designations. The legislation would revise the activities and structure of the State Planning Office in relation to capital programming by all governments in the state and all land use decisions which affect more than one governmental jurisdiction, plus increasing the authority and membership of the Council on State Planning,

Within a year of the effertive date of the law, the State Planning Office would submit its recommendations on minimum standards in land planning and critical areas to the Council on State Planning. After public hearings and possible revisions, the council is to transmit j.ts findings and opinions to the Governor. The Governor must approve the minimum standards and critical areas within 45 days after their receipt, or the Council's recommendations expire. Upon approval by the Governor, the proposal must be approved by resolution of both houses of the legislature within 45 legislative days or 
it is considered rejected. Rejection by either the Governor or the legislature would send the measure back to the Council for revision. Within one year after adoption, all plans and standards of counties and local governments must be revised to comply with the statewide minimum standards and critical area designations.

Commentary on CZA and its Future

Since the 1.970 development moratorium in the coastal zone and subsequent passage of CZA in 1971, Delaware has had time in which to plan for the orderly growth of j.ts highly-valued coastal region. CZA must be viewed as an interim measure, taken in direct response to concerns over imminent industrialization of this area. The genesis of the law; and particularly the pressures of time -the year's moratorium on development was due to end on June 30,1971 , only two days after the new legislation became law -- in part determined the CZA's singular nature. It is not a comprehensive planining document setting out in positive terms how the people of Delaware wish to accomodate inevitabJe growth. Rather, it proclaims certain developments which are not wanted for the area. While the law has been effective in achieving its purpose, many other types of development -- including housing sub-divisions, commercial establishments and intensive recreational facilities -- which also can have considerable impact on the coastal zone, are not covered by the legislation. CzA was, however, a good first step in formulating a comprehensive coastal zone plan for Delaware.

Contrary to the understanding of some that CZA has completely stopped all energy development in the coastal zone; the account above of certain approvals (as well as permit denials) under the act should provide balanced perspective.

At this point, it is uncertain how the proposed new law, if it were enacted, 
would affect the current ban on heavy industry in the coastal area. There are indications that support for coastal preservation is still very strong, but a realization may be setting in that certain energy facilities may have to be located on or near the coast, albeit in areas that are least sensitive to environmental degradation. This is in part a reaction to the advent of Outer Continental Shelf oil drilling off the coast of Delavare. Other Land Use Laws Related to Energy Facility Siting

The 1972 Beach Protection Act gives state.review powers up to 1,000 feet. from the low water mark. This includes authority to designate "no construction" zones seaward of dunes. Localjties retain their authority inland from the dunes. 29

The Wetlands Act of 1973 requires that a permit be obtained from the Department of Natural Resources and Envirnnmental Control for certain activities in the designated area, such as dredging, filling, dumping and construction. 30 The act has a feature similar to one established in CZA, in relation to state acquisition of wetlands after a court has decided that the state's action in denying a permit constitutes a taking without just compensation. Instead of the five years granted in CZA, the Secretary of Natural Resources and Environmental Control has two years from the court decjsion to initiate acquisition proceedings. After that period, if the land is not acquired the permit must be granted as requested.

Tidal wetlands comprise a significant portion of the state's coastal resources. These $12.0,000$ acres are important not only to the state, but to the entire Atlantic Coast as breeding grounds for commercial fishing and as feeding areas for migratory waterfowl using the Atlantic Flyway. These wetlands have been threatened by development. The state Division of Fish 
and Wildlife estimated the rate of loss of wetlands in the 1960's at about

1 percent per year, or about 1,200 acres annually. About 60,000 acres of

Delaware's tidal wetlands (50 percent) are owned by state, federal and private conservation groups, and it has been proposed that the state acquire an additional 26,700 acres by the year $20000^{31}$ The 1973 Wetlands Act was an important step in preserving these ecologically fragile lands.

\section{Nuclear Energy Reassessment}

In June, 1975, a bill was introdured in the House to postpone construction of nuclear power plants temporarily pending evaluation of the short- and longterm consequences of such facilities. ${ }^{32}$ This study would be carried out. by a Nuclear Power Evaluation Committee consisting of five members of the public appointed by the Governor, plus the chairmen of environmental and energy-related committees of the legislature. The statement of intent in the bill. declares:

"Because in many states nuclear fission is seen as a panacea and a cheap substitute for fossil fuels and because many states, including Delaware, appear to be rushing into the field of nuclear fission and permitting the building of nuclear generating plants without a clear knowledge of the assets and liabilities involved, there has been a recent increase in the number of commercial nuclear plants bejing buil.t and planned...

It is the purpose of this Act to permit the state of Delaware to stop, take a deep breath, and carefully examine the whole question. of commercial nuclear generating plants. It i.s alleged by opponents of commercial nuclear power that there have been more accidents at existing nuclear sites than is generally known by the public, and that there have been failures or near failures of warning and fail safe systems previously thought to be free of error. This Act provides for a Nuclear Power Evaluation Committee which would research the whole question of 'commercial nuclear energy as it applies to the State of Delaware, and make its report to the General. Assembly."

This legislation has not been acted upon, primarily because Delmarva's Summit 33

proposal was wi.thdrawn. 
In January, 1975, a House Resolution urged the Delaware Congressional Delegation to investigate the proposal by the President of the United States to increase taxes on crude oil and gas. ${ }^{34}$ Delaware legislators were concerned about the financial impact of this action on the state and its residents. $^{35}$ In February, 1975, a law was enacted removing the oil depletion allowance as a deduction on both state corporate and personal taxes. The stated purpose was to raise badly-needed revenue. 36

In January, 1975, the legislature enacted a bill to license petroleum refineries in the state and levy upon them a tax of 10 mills per gallon of crude oil processed. $^{37}$ This measure was vetoed by Governor Tribbit in February, 1975. The reason given for the Governor"s veto was that the state's only oil refinery, a 140,000 barrels per day facility at Delaware City owned by the Getty oil Company, threatened to close down if the tax measure became law. According to Sylvia Short of the Delaware Legislative Council, Getty brought in very articulate, out-of-state attorneys to argue its case, culminating in the Governor's action. 38

The issue, however, did not end there. In a sharp exchange of correspondence between Governor Tribbit and federal. Internal Revenue Service (IRS) Commissioner Donald C. Alexander later in 1975, the Governor requested and was denied a meeting to discuss a joint state-federal audit of Getty. This request was a result of accusations by the Delaware Citizens Coalition for Tax Reform, and Getty's response that it was audited every year by both IRS and the Federal Energy Administration (FEA). The Governor requested a joint conference between representatives of the state of Delaware, IRS and FEA to discuss the types of audits performed, the regularity of those audits, and particularly tanker costs 
and transfer cost of feedstock. ${ }^{39}$ In an October, 1975, letter to IRS Commissioner

Alexander, Governor Tribbitt stated:

"Your letter of October 8, 1975, in which the Internal Revenue Service rejected consideration of a joint state-federal audit of Getty 0il Company - without even the courtesy of a conference on the matter - points out only too clearly the States' difficulties in dealing with the Federal bureaucracy.

On the one hand, the Federal Energy Administration, which was requested to take part in such an audit if it was deemed to be jointly useful, readily agreed to participate in such a conference.

Yet the IRS, in a letter under your signature, asserted it would "be unable to participate in such a suggested conference,' claiming it does not feel a joint audit should be made. What is your justification for such a decision?...

A recent edition of 'Tax Notes,' published by the Washington based group, the llax Analysts and Advocates, stated thut "the request by the Delaware Governor...raises fundamental questions about the ability of a state government to enforce its income tax laws, with respcct to multi-national corporations...' The newsletter added that 'failure to respond to the Tribbitt request would put the IRS in the posicton of cooperating with tax audits conducted by foreign nations, while refusing similar assistance to state authorities.'

...It is my firm opinion that the IRS is brushing off as trivia1, a matter which could well be presedent-setting in nature, and which could prove important for this, and all other State governments, concerned with assuring that all. taxpayers - corporate and privace - pay ill tue and just taxes,

May I remind you that on February b, 1.974, you sent me d lelter in which you discussed a 'desire for a closer Federa1 and State information exchange?' You said you were working towards an 'improved interface, as soon as possible." Let me suggest that such an improved intcrface might begin now, with your cooperation.

'lhere is nn question that it is beyond the ability of the various State tax-collecting agencies to independently audit the returns of multinationa1 corporations which have, over the last decade, proliferated in our country. By their very size, such corporations are potentially the largest payers - or potentially the largest avoidere - of corporate income tax and other business taxes that are owned both to the Federal government and to the States.

Your excuse that 'our current agreement concerning the coordination of tax administration does not provide for joint audits, merely indicates to me that now would be an excellent time for you to update 
your thinking and revamp policies which appear stagnant, unhelpful and, indeed, obsolete.

In your letter sent this month, you assert that initiating such a joint audit would 'seriously affect our (the IRS's) operations." The IRS, like every other institution of the Federal government, derives its powers from the consent of the governed. Just whom do youl think the IRS should serve, if not the people?

The brusque turn-down of a request by a Sovereign state to an Agency of the Federal government is an affront to the entire historic concept of the state/Federal. relationship. Therefore, with improved communications in mind, I request that you make arrangements to meet. with me, at your earliest convenience, in my Dover office, to explain to me - and thereby to the citizens of the State of Delaware - the IRS's decision in this matter.

The letter from Commissioner Alexander dated October 8, 1975, to which the

Governor referred, made the following points:

"Our current agreement concerning the coordination of tax administration does not provide for joint audits. It does, however, provide for the exchange of information on audit adjustments made by our respective offices. Accordingly, any audit adjustments resulting from any examinations of tax returns filed by Getty Oil Company which are conducted by our District Director in Ios Angeles, who has jurisdiction in the matter, will be made available to you. We are forwarding a copy of your letter to that district for their information.

We have given careful consideration to the feasibility of a joint audit and the benefit to be derived from a meeting with your representatives. The basic purposes of the Federal-State agreements are to avoid the duplicate use of resources in tax administration. To initiate a program of joint audits with the States would seriously affect our operations. Accordingly, we do not feel a joint audit should be made.

Although a current agreement does exist providing for an exchange of information by our respective offices, we do not have a comparable agreement with the Federal Energy Administration. The participation of Internal Revenue Service personnel in a joint conference with your representatives and those of the Federal Energy Administration could create a disclosure problem. Therefore, we would be unable to participate in such a suggested conference."

The "Agreement on Coordination of Tax Administration with the State of Delaware!" signed in 1975 by IRS Commissioner Alexander and Governor Tribbitt makes specific reference to information which may be exchanged as: "data relating to the production, processing, and transportation of fossil fuels, 
minerals, and other natural resources." Tax Analysts and Advocates of

Washington, D.C., concluded as follows in their. October 27, 1975 Tax Notes

report:

"A public affairs spokesman for the IRS in Washington said the Commissioner's response may have been rather curt but that it was, nevertheless, the correct response. Agreement, he said, woul.d have set a precedent that would have been taken advantage of by so many states that there would be no agents left in the national office...

According to a former IRS official, the exchange of information between IRS and foreign governments when both suspect tax revenues are being lost, a practice that has been cited as a precedent for similar federai-state cooperation, is generally instigated at the request of the United States. It is not likely, he said, that the U.S. would provide substantial assistance to a foreign government iff the request were along the lines of "We think there is something wrong here; l.et's take a closer look.....'

Consideration should be given to the legitimacy of the state's claim and to the inability of a state, particularly a state the size of Delaware, to conduct a thorough audit of the international operations of a multinational corporation. And the federal Treasury would reap the benefits of any adjustments since the federal tax rate is $48 \%$ compared with Delaware"s $7 \%$ rate." 40

In microcosm, this incident points to the broader question of tax benefits from energy facilities, especially when large multinational corporations are concerned. This issue has clear relevance to energy facility siting policy. Often, the tax benefits to be derived by the governmental jurisdiction constitute the principal rationale for permitting oil refineries and other such energy facilities to locate in an area, causing probable deleterious effects to the environment. If a state (or loçal government) cannot arcurately assess the extent to which such tax payments are due, it is at a distinct disadvantage. This is especially true if its tourist and recreational revenues --- particularly in a coastal area -- are likely to be diminished as a result of locating an energy facility in the area. The state and its localities thus may be deprived of the full concomitant financial compensation for such losses. As a result, 
the large "sweetener" which often persuades reluctant communities may be diminished in importance when the true cost/benefit ratio is weighed in. decisions on energy facility siting.

\section{Dther Energy Legislation}

In a 1975 resolution, the House requested the Delaware Society of Professional Engineers to make a study relating to more efficient use of space heating and cooling equipment within all state-owned buildings' including schools. 41

On. May 28, 1976, a bill requiring public hearings on all applications to change the fuel. adjustment rate became law. The measure proclaimed:

..."customers of the Delmarva Power and Light Company have been shocked. at the large increase in their electric bills caused by application of the special Fuel Adjustment Clause; and...the Fuel Adjustment Clause has been applied by the said utility with only pro forma approval by the Public Service Commission, withont benefit of the adversary proceedings normally required for rate changes;... such hearings are necessary so that the public may know of impending changes in the utility rates and may offer evidence." 42

The Public Service Commission (PSC) was directed in a 1.975 Senate

Resolution to adopt regulations requiring utility companies in the state to institute and publish a customer Bill of Rights establishing certain procedures for resolving customer complaints. The following rationale is stated in the bill:

..."public utility companies are somewhat monopolistic and are free to ignore legitimate customer complaints thus leaving frustrated customers with little or no remedy...

The PSC has adopted no adequate regulations requiring the public utility companies to establish procedures to resolve customer complaints...

Such procedures including various guidelines are necessary and essential in order to assure the citizens of Delaware that their complaints will be heard and considered by the public utility companies." 43 
Energy has not been a legislative priority in Delaware, and the state does not have a broad-scope Energy office to stimulate and coordinate energy measures, especially for energy conservation. Only in August, 1976 was this lack somewhat addressed, when by executive order Governor Tribbitt created an energy advisoiry commission. Since Governor Tribbit was defeated for reelection in November 1976 by former Congressman Pierre S. DuPont, the future of even this limited move is uncertain. Neither does Delaware have energy facility siting legislation to offer regulation and guidelines on the location of such high impact factlities. This is especially important in a state like nolaware, with its limited geographic space.

Decisive action was taken in 1.971 to preserve the coastal area, highly valued by the people of the state. This was an interim step taken in response to a forceful set of circumstances. Delaware in 1976 is in the midst of establishing a comprehensive land planning mechanism for the entire state. In some form, this proposal. ultimately will supersede CZA, and may well decide the future of the coastal zone and of energy facility siting in the state as a whole. 
1. Earl H. Bradley, Jr. and John M. Armstrong, A Description and Analysis of Coastal Zone and Shoreland Management Programs in the United States (Ann Arbor: University of Michigan, Sea Grant Program, Technical Report No. 20: March 1972), p. 252.

2. Interview by Grace Singer, Princeton University, Center for Fnvironmental Studies Researcher with Sylvia Short, Librarian, Legislative Council of Delaware, June 21, 1976.

3. Council of State Governments, State Responses to the Energy Crisis (Lexington, Ky.: CSG, March 1975), p. 28.

4. Federal Fnergy Administration, National Energy Information Center, Directory of State Government Fnergy-Related Agencies (Washington, DC: FEA, September 1975), p. 19.

5. Interview by Singer with Michael Thompson, Fnergy Planner, Delaware State Planning Office, May 25, 1976.

6. Interview with Short, op. cit.

7. Interview with Thompson, op. cit.

8. Interview with Short, op. cit.

9. Chapter 70, Tjtle 7, Delaware Code.

10. "A Summary of State Land Use Controls," Land Use Planning Reports, July 1974, p. 11 .

11. Bradley and Armstrong, op. cit., p. 251.

12. See David Morell and Martin Wohlforth, Issues in Energy Facility Siting: A Case Study of a New Jersey Oil Refinery Decision (Princeton, NJ: Princeton University, Center for Environmental Studies), report forthcoming, 1977.

13. Ibid.; and interview with Thompson, op. ci.t.

14. Interview with Thompson, Ibid.

15. Ib1d.

16. Bradley and Armstrong, op. cit., p. 251.

17. State Coastal Zone Industrial Control Board and Delaware State Planning Office, Coastal Zone Administration - June 28, 1971 to June 30, 1975

(Dover, Del.: State of Delaware, July 1975), p. 1.

18. Ibid., p. 12 re CZA permit decision on First State Pipeline Company. 
19. Ibid., p: 14 re CZA permit decision on El Paso Eastern Gas Pipeline Company.

20. Ibid., p. 1.7 re CZA permit decision on Sun Oil Company of Pennsylvania.

21. Ibid., p. 43 re CZA permit decision on the Defense Fuel Supply Center at McGuire Air Force Base in N.J.

22. Ibid., pp. 13, 44-46.

23. Ibid., pp. $7,8,34$.

24. Interview with Short, op. cit.

25. Report of the Delaware Tomorrow Commission to the Honorable Sherman $W$. Tribbit, Governor of Delaware (Dover, De1.: Delaware Tomorrow Commission, January 1976), pp. 45-46.

26. Ibid., pp. 43-44.

27. An Act to Amend Chapter 91, Title 29, Delaware Code, Relating to State Planning and Providing for the Establishment of Statewide Minimum Land Planning and Land Management Standards and Critical Areas, May 12, 1976.

28. News Release from Delaware Tomorrow Commission Chairman 0. Francis Biondi, Esq., June 9, 1976.

29. "A Summary of State Iand Use Controls," op. cit., p. 1.1.

30. Chapter 213.

31. Bradley and Armstrong, op. cit., p. 262.

32. $\mathrm{HB}-528$.

33. Interview with Short, op. cit.

34. HR-18.

35. Interview with Short, op. cit.

36. Ibid; this law was introduced as $\mathrm{HB}-137$.

37. This law was introduced as HB-97.

38. Ihid.

39. Tax Analysts and Advocates, Tax Notes, Volume III, Issue No. 43 (Washington, DC: October 27, 1975), p. 9 .

40. Ibid., p. 10 .

41. HR-102. 
42. This law was introduced as $\mathrm{S}-7$.

4.3. SR-28. 


\section{THE NEW ENGLAND REGION: * \\ RELT.ANCE ON PETROLEUM AND REJECTION OF REFINERIES}

\section{Introduction}

Two major characteristics of the New England region strongly influence energy policy issues. First, the area's industrial, utility and residential sectors rely upon petroleum products for more than 80 percent of their total energy requirements. All. these petroleum products must be imported from outside, placing the region in an energy-dependent position. In addition to lacking 1Ls own sources of oil, New Fngland has no refineries nor deepwater ports (although a proposal for a refinery in Eastport, Maine is pending). Much of this heavy dependence on oil, greater in this region than anywhere else in the country, is related to its location at the very end of the fuel distribution lines and to the fact that, although gas pipelines were constructed in many other parts of the country, they never quite made it to New England. The effect of these circumstances has been that other regions have had the advantage of inexpensive fuel, placing New England's industries at a competitive disadvantage.

Faced with an overdependence on imported oil and sharply escalating oi.1 r.nsts; a result of the 1973-74 OPEC boycott, the states of the region searched for alternative energy sources -- but without much success. Any widespread use of coal threatened to violate air quality standards. New England was already more committed to nuclear power ( $16 \%$ of total generation) than any other section of the nation, but serious problems with those nuclear plants already in operation hampered further rapid advancement (see Chapters on New Hampshire and Vermont). 1

\footnotetext{
* Connecticut, Maine, Massachusetts, New Hampshire, Rhode Island and Vermont.
} 
One promising element in the New England energy picture is the region's current electricity reserve generating capacity of approximately 46 percent, of which only 20 to 23 percent is necessary to maintain reliability during periods of peak demand. This reserve capacity was developed during the 1960's when construction costs for new power plants were much lower than at present. ${ }^{2}$ $\Lambda 1$ though current excess reserve generating capacity represents a carrying cost to the region's utility customers, New England will not be forced to add as many new generating facilities over the next decade as will other areas. of the country. This offers the hope of a somewhat more equitable competitive situation to this region which to date has suffered inordinately high energv costs. New England's energy dependence, particularly in this cold area of the country, has placed a heavy financial burden on consumers of electricity and heating oil. In addition, electric power costs historically have been higher in New Fngland than the national average. This differential has been reported as high as 50 percent in the $1940^{\prime} \mathrm{s}, 15$ percent around 1960, and 33 percent in 1968. According to a 1970 study by the New England Regional Commission, the high cost of electricity was attributed to the large number of utilities and the small size of their loads and service area. The Commission recommended formation of an agency with authority to locate and construct new generating and transmitting facilities throughout the region. This revived the controversy that erupted 50 years ago over the proposed Passamaquoddy tidal power project in Maine, and has continued in one form or another since. A 1973 attempt. to set up a New England regional power and environmental protection agency

* The Chairman of Northeast Utilities has stated that the cost of 24 million barrels of oil had risen from about $\$ 50$ million in 1969 to $\$ 325$ million in 1974. Between 1973 and 1974 alone, New England's total energy bill rose by 139 percent, or roughly $\$ 1.2$ billion. The increase in this region was close to three times the national average on a per capita basis, causing enormous economic displacement. ${ }^{3}$ 
modeled after the Tennessee Valley Authority "to compete with private. utilities and thereby bring down the price of power" was unsuccessful. It was claimed that economies could be achieved by taking advantage of mass purchasing, avoidance of high dividends and corporate salaries, and solicitation of federal subsidies for construction of power plants. ${ }^{4}$ Public power advocates alleged that a major obstacle to achieving this regionalized approach was the influence of New England's private utilities, whose "massive propaganda campaigns, financed indirectly through customer electric charges, have defeated them repeatedly in the legislatures and at the polls." ${ }^{*}$ In fact, public power accounted for only 2.7 percent of New England's operating power plants in the early 1970's. Vermont is the only state with a significant share (21.4 percent) of public-owned power. This is attributed to the efforts of former Governor and Senator George D. Aiken, among others whn champinned the public power cause. 6

The region's second major characteristic relates to its natural resource amenities; which make it a highly desirable place to live and work. This favorable environmental quality has created strong sentiment in both public and private sectors to protect the region's natural resources from the potential impacts of proposed new energy facilities. 7

The legislative intent and content of the various state laws regulating energy facility siting emphasize this latter concern, particularly in their approach to oil refineries. Authority for the state to over-ride. the expressed wishes of local governments, available for power plant siting, is notably absent with

$\star$

In 1973 the voters of Maine rejected a proposed state public power authority.8 As recently as November 1976. an initiative measure for publicowned power plants was rejected by Massachusetts voters, although public power is planned for that state.9. 
respect to refinery siting, a controversial issue in which several states have passed legislation expressly granting veto power to local governments. This important distinction between siting processes for power plants and oil refineries is especially noticeable in New England, a response to earlier proposals to construct a deepwater port in Maine and a refinery at Durham, in coastal New Hampshire. Table 1 illustrates public concern and resistance to locating oil refineries in New England.

Table 1

New England Refineries P1anned But Not Constructed Due to Public Opposition

Company Location Size (Barrels/Day)

Maine

$\begin{array}{lll}\text { Maine Clean Fuels, Inc. } & \text { South Portland } & 200,000 \\ \text { Maine Clean Fuels, Inc. } & \text { Searsport } & 200,000^{*} \\ \text { Occidental Petroleum Co. } & \text { Machiasport } & 300,000\end{array}$

New Hampshire

Olympic Oil Refineries, Inc.

Durham

C.H. Sprague \& Son, Inc. Newington

Rhode Island

Commerce Oill Co.

Jamesport Island

(Narragansett Bay)

50,000

Northeast Petroleum Co. Tiverton

$$
\text { TOTAI, } \frac{65,000}{1,065,000}
$$

* This refinery is the same as the one proposed at South Portland. Thus the total capacity rejected in New England is $1,065,000 \mathrm{~b} / \mathrm{d}$. The siting incidents, however, are independent and additive.

Source: National Independent Refinery Development Act of 1975, Hearings before the Committee on Interior and Insular Affairs, United States Senate (Washington, DC: U.S. Government Printing Office, 1975), p. 190. 
Thus, one finds the ironic situation of an area heavily dependent on petroleum taking special legislative action to ensure local control (veto power) over new oil facilities. It has been suggested that what the region needs to deal with the onshore infrastructure pressures of offshore oil extraction, including refineries, is a New England interstate authority to compete on leases with the oil companies in order to grasp the proposal and turn it to the region's economic advantage, while ensuring adequate environmental protection. ${ }^{10}$ The New England area has a unique regional institutional mechanism -the New England Regional Commission -- engaged in extensive data gathering. and exchange among the six states on energy, among other matters. This Commission is a federal/state partnership comprised of the six New Fngland governors, plus a federal co-chairman appointed by the President of the United States who shares the chairmanship with one of the governors. The Commission was created in 1965. ${ }^{1.1}$ The goal of the Commission's Energy Research and Policy Formulation Program is to supply Commission members with reliable baseline information on New England's energy requirements and vulnerabilities, and to provide the region's governors with energy policy alternatives for future planning and program coordination. The Commission's Energy Program staff works closely with energy advisors to the six governors and with Energy offices in each state. Preparation of this chapter relied heavily on this unique regional source of information.

Although a number of other approaches were equally feasible, this chapter has been structured in terms of each of the six states, alphabetically, followed by a brief summary of overall trends and policy issues in New England as a whole. The primary focus has been on energy facjlity siting legislation, although some related information has been included on other aspects of 
energy policy. Time constraints precluded analysis of legislative structure in each state.

\section{Laws Affecting Energy Facility Siting in Connecticut}

In 1975, Connecticut enacted legistation parallel to that of several other New England states to provide for local voter approval of oil refineries. The state's act requires that, upon submission of a petition signed by at. least 5 percent or 200 of a town's voters, whichever is greater, the town hold a referendum on the question of whether an oil refinery may be constructed in that jurisdiction. Construction is prohibited if a majority of voters disapprove of the refinery..$^{12}$ Thus, Connecticut joined New Hampshire and Massachusetts which had earlier passed legislation allowing for explicit local "home rule" over oil refineries, indicative of the concerns of the region heightened by the prospects of Outer Continental Shelf drilling for oịl and gas on top of the controversies in Durham, N.H. and Machiasport, Me.

Power. Plant and Pipeline Siting

The Public Uti].ity Environmental Standards Act of 1971, as amended, is the principal legislation governing siting of energy facilities in Connecticut. This act established the Power Facility Evaluation Council $(P F E C)$, giving it the lead coordinative and regulatory role for issuing Certificates of Environmental Compatibility and Public Need for power plants and related facilities, and for oil and gas pipelines. Membership in the PFEC consists of the Commissioner of Environmental Protection, Chairman of the Public Utilities Control Authority (PUCA), or their designees, one designee of the Speaker of the House and one of the President pro tem of the Senate, plus five members of the public appointed by the Governor, at least two of whom must be experienced in the field of ecology. Not more than. 
one of these five public members can have an affiliation, past or present, with a utility, governmental. utility regulatory agency, or the like. Utilities must submit annual 10-year forecasts; 20-year load and reserve forecasts must be submitted every other year. Before reaching its decisions on applications for certificates, PFEC must consult with the Departments of Envi.ronmental Protection and Health, and with the state"s Council on Environmental Quality. This is to assure that the proposed facility complies with other permit requirements under state and federal law. However, if any conflict exists. with other state statutes, this siting act is to take precedence.

PFEC holds adversary procedure hearings prior to its decisions. Any. appropriate state or local official may testify, and qualified non-profit organizations such as environmental, consumer or commercial/industrial representatives may become parties to the hearing. The proposed facility!s cumulative effect on environmental standards, reliability of service and upgrading of facilities must all be considered.

The Connecticut Public Utilities Contro1 Authority operates in conjunction with PFEC relative to approval of power plant construction. PFEC, however, holds final authority pertaining to location of facilities, and has override powers over the decisions of all other state agencies. PFEC can authorize eminent domain proceedings for site acquisition, thereby over-riding local authority concerning power plants and pipelines (though not for refineries). Energy Planning and Policy Formulation

PFEC works in concert with the Department of Planning and Energy Policy created in 1975 to develop and implement a statewide energy p1,an. ${ }^{13}$ This new Department is empowered to develop and implement energy policy and emergency 
planning for the state, as well as to prepare and submit to the State Planning Council overall land use, water resources, labor, housing, and other plans. other functions include those normally performed by a State Energy office. The new Department is a more powerful and coordinated energy planning mechanism than exists in any other state of the Northeast.

The 1975 statute also established a new Energy Advisory Board, which is required to submit an annual energy resources report to the Governor and the legislature. This report must contain data pertaining to the state's energy requirements for the ensuing 20 years, recommendations for bringing energy supply and demand into balance, and suggested policies for energy conservation, control of demand, development of new sources of energy, and licensing of oil refineries, deepwater ports, nuclear power plants and offshore drilling facilities or other similar major capital entities. The Board's report also must identify any beneficial or adverse social, economic or environmental impacts of its projections and recommendations. 14

\section{Nuclear Regulation}

Another item of legislation in 1975 created a Temporary Nuclear Power Evaluation Council, consisting of eight persons with inter-discịplinary backgrounds appointed by the Governor. This Council is to evaluate whether the state can and should regulate nuclear power plants and related nuclear fuel. cycle facilities. The Council's studies are to include nuclear power plant quality assurance programs, environmental effects of radioactive and thermal effluents, transportation of radloactive materials, plant employee safety, emergency procedures and security systems. Originally, the Council was to report its findings to the General Assembly by February 1, 1976; but its hearings were still in progress as of late 1976, and the due date for this 
report was extended by a year. ${ }^{15}$

Pollution Control

Several state water protection statutes require permits for activities related to their jurisdictions, and thus may influence siting of energy facilities. These are:

Water Resources Act (1963)

Water Pollution Control Act (1967)

Preservation of Tida1 Wetlands Act (1969)

Inland Wetlands and Watercourse Act (1972)
- Regulating construction within a flood plain and other activities in coastal waters;

- Regulating discharge of any substance into state waters;

- Tidal wetlands are to be inventoried and protectcd;

- Inl.and wetlands are to be inventorịed and protected. 16

The state's Air Pollution Control Act (1971) functions in the traditional manner, and would be a further consideration in energy facility siting. 17

All terminals for discharge or loadlug of oil must bo lirensed pursuant to the Oil Pollution Iaw of 1969, amended in 1972. ${ }^{1.8}$ Anyone causing contamination of land or water by reason of such operations is liable for the cost and expense of the cleanup. Operators of vessels in state waters discharging or receiving oil or bulk petroleum products must post a $\$ 50,000$ bond with the Secretary of 3 Late to reimburse the state for the coet of nil spill. cleaulu.

Pursuant to the Environmental Protection Act of 1971, the Department of Environmental Protection (DEP) exercises general supervisory and coordinariry powers in a11. areas of nautral resource protection, pollution abatement, and mining or extraction. 19

The State Environmental Policy Act, effective in 1975, includes many of the features of the National Environmental Pollcy Act (NEPA) of 1969. Each Connecticut state agency must review its own policies and practices for consistency with the declared state interest in preservation and restoration 
of environmental resources. Toward that end, such agencies are required to prepare written assessments of their actions "which may significantly affect the environment," using long- and short-term cost/benefit analyses and giving due consideration to adverse effects and alternatives. Review of these evaluations is within the purview of the State Planning Council, which is to make "written recommendations to the Governor regarding the proposed state action, which recommendation shal1 be made public." 20

\section{Conclusions}

In recent years, particularly in 1975, Connecticut's legislature has been very active in enacting legislation bearing on energy facility siting. During that year, more significant new energy legislation was enacted in Connecticut than in any other state in the Northeast. Of particular note is the state"s energy planning mechanism, which is coordinated with land use and other resource planning; its Nuclear Power Evaluation Council; amendments to its siting procedures; and the local referendum process giving "home rule" authority cver approval of oil refineries.

The state is now actively involved in development of an energy resources management plan which could result in state initiatives in energy facility siting, rather than the current reactive posture which it shares with most other state governments across the country.

Although Connecticut's energy laws are comprehensive and appear generally to offer good coverage, no centralized permit authority exists for oil refineries or deepwater ports. Such approvals would be tied to the numerous regulatory proceduxes for issuing aix and water pollution control permits through the Department of Environmental Protection. 
In 1974, Maine's present Governor Jame's Longley was elected as an Independent candidate, ${ }^{*}$ with a policy explicitly opposed to locating oil refineries in the state. Thus it is perhaps symbolic that Governor Longley noted in a June 1976 interview that the state's environmental agency had recently approved Maine's first such facility. He appeared to accept this development with the statement: "So be i.t, if it wil.1 help solve Maine"s energy problems." 21

Siting Laws and Land Use Controls

Since 1967, numerous locations on the Maine coast have been proposed for huge oil refineries and deepwater ports. These proposals range from the wel1-publicized Machiasport plan to the current proposal by the Pittston

\footnotetext{
* Longley was the first Independent to be elected Governor in the United States. $* *$

The Machiasport plan was conceived by an independent oil promotor whose
} interest was bought out by occidental Petroleum. The plan called for construction of a $\$ 150$ million refinery beside the 100-foot deep waters of Machias Bay, 25 miles from the Canadian border. To accommodate the plan, the Maine Port Authority applied to the federal government for a foreign trade zone so that Occidental could import some 300,000 barrels a day of Libyan oil, process it, and pay duty only when it sold its product of 100,000 barrels a day (primarily residential heating oil) in New England markets. When a special import quota was requested, the proposal ran into sharp opposition from major U.S. cil companies who objected to any circumvention of the o11 import quotas that had given them protection in the high-price New England market. The plan was enthusiastically backed by top officials in Maine, including Governor Kenneth M. Curtis and Senator Edmund S. Muskie (both Democrats), who claimed that the area was "suffering from severe economic dislocation and poverty" and needed new development. 'l'he Machiasport proposal did not become a real1ty, primarily because neither the Johnson nor Nixon Administrations wanted to fight the Texas-Lousiana oil combine which was opposed to the foreign trade zone plan. In addition, conservationists pointed out that the bay is near the mouth of the Bay of Fundy, which has the highest tides in the world, plus other extremely hazardous navigational features. They recelved strong editorlal backlng from the Maine Times, which in September 1970 stated:

"Downeast Maine is one of the last great unpolluted, undamaged coastlines in the entire world. It is a magnificent resource of immeasurable value that belongs not only to the people of Washlngton County and Maine, but to the entire population of the northeast coast, the United States and the world... The proposed oily work at Machias does not have to be done. The alternative to oil is no oil." 22 


\section{*}

In 1973, when the energy crisis was looming, a 250,000 bbl.-a-day refinery and supertanker terminal was proposed at Eastport on the Atlantic Ocean at the Canadian border. This complex would cost $\$ 500$ million, and be built and operated by the Pittston Company, a New York energy conglomerate (coal, oi1). Once the sardine canning capital of the world, Fastport-- the easternmost city in the United States -- has a high unemployment rate due to the decimation of its fishing fleet by tough competition from foreign factory ships. Pittston's proposa! involves importing crude oil in supertankers over 250,000 tons and pumping the oil into holding tanks. After refjining, the oil would be taken out in smaller tankers and barges for distribution. Conservationists raised arguments centering on hazardous navigational. conditions similar to those used against Machiasport and other oil developments in this area. This proposal, however, had the backing of the Maine Times and more cooperation from Washington than was evident in the Machiasport case. In addition, Pittston had technical expertise and financial resources not evidenced by previous oil development. bidders in Maine. The Maine Board of Environmental Protection in June 1975 gave its approval to the proposal, and the matter remains pending as of this writing. There had been complications with the Canadian government, which in 1973 lodged an official protest charging that the proposal "presents an unacceptable risk in the transport of a large volume of pollutants through these difficult waters,"23 These objections were reiterated by Canada at a December 1976 hearing on the project, 24 If given final approval, the Pittston facility would become the first oil refinery in New England.

In recounting energy facilities rejected in Maine, it is interesting that one such rejection came in January 1977 from the U.S. Nuclear Regulatory Commission (NRC) for an 1150 megawatt, \$1 billion nuclear power plant proposed at Sears Island in Penobscot Bay. Studies at Sears Island revealed a 12,000 year old geological fault. NRC rules prohibit construction of a nuclear power plant above a fault which has had active earth movement in the last 35,000 years. The utility, Central Maine Power Company, may build a coal-fired plant on the site and has deferred plans for another nuclear plant until the 1990's. ${ }^{25}$ In 1970 an oil refinery proposed for Sears Island by Maine Clean Fuels was rejected by state officials who decided that the company lacked the finances or technical expertise to meet Maine's antipollution standards. 26 
The furor created by pressures for oil development contributed significantly to the passage of two stringent state laws in 1970 , the Site Location and Development Act and the Oil Discharge and Pollution Prevention Control Act, both described below. ${ }^{27}$ Both laws were legally challenged by oil companies whose objections were rejected by the courts. 28

Maine has the most comprehensive legal and institutional structure for energy facility siting among the six New England states, ${ }^{29}$ and its siting law is the oldest such statute in the region. The law provides centralized authority to the Board of Environmental Protection (BEP).

The purpose of the Maine Site Location of Development Law of 1970 is to ensure that location of development is consistent with the social and economic well-being of the population, and that impacts on natural resources are fully considered in reaching major siting decisions. ${ }^{30}$ The statute is not exclusjvely for energy facility siting, but covers all proposed development of land or water in excess of 20 acres, or which requires a license from BEP, or which involves drilling for natural resources. The siting law applies to various energy facilities -- including power plants, oil refineries, oil wells, deepwater ports, transmission lines, and pipelines -- as well as to other large-scale industrial, commercial and residential developments.

BEP is a multi-interest entity consisting of ten members appointed by the Governor, plus the Commissioner of Environmental. Protertion whn serves ex officio as BEP Chairman. ${ }^{31}$ Criteria specified for issuance of a permit by BEP include: financial capacity to meet air and water pollution control standards, compatibility of the proposed development with existing uses, preservation of the natural environment, provision for traffic flow, and suitability of the soils. 
Prior to construction, a developer is required first to obtain local approval. However, the law confers upon BEP negative authority to override local approval. Although BEP has the sole authority for siting approval at the state level, letters of review from other responsible state agencies must be considered in the developer's record of intent, e.g. the Soil and Water Conservation Commission, State Department of Transportation, Division of Sanitary Engineering, State Planning office, and the Departments of Marine. Resources and Inland Fisheries and Wildliffe.

Hearings are not conducted unless an applicant requests one after BEP's initial. decision, or unless BEP chooses to hear the case orally. However, it. has been BEP's practice to conduct public hearings on all projects of major consequence. $^{32}$ Mandatory hearings are limited to objections to BEP's findings. Notice of the hearing must be published in a newspaper in the proposed locality at least 1.0 days prior to such a hearing. Although there is no requirement for the hearing to be held in the locality of the proposed development, BEP has always done so. ${ }^{33}$. Any appeals from BEP's decisions go directly to the Maine Supreme rourt. When complex hearings are held, the pub]ic participation procedures under the BEP's regulations provide for:

- convening prehearing conferences twn to three weeks prior to hearings to expedite the orderly conduct and disposition of the proceedings. Notice is given to the applicant, intervening parties and others deemed appropriate to participate.

- conferring intervenor status on those who wish to offer testimony and who can demonstrate jinterest in the proceedings and capability to participate.

- providing an opportunity for interested persons to give oral and written statements concerning the proposal, as well as to attend and participate in prehearing conferences. However, only individuals classified as intervenors may cross-examine other witnesses.

- granting government agencies on federal, state, municipal or other levels rights similar to those granted to intervenors, as long as their agents represent the views of such agencies. 34 
In practice, all project-related materials available to BEP are made available for public review at least one week prior to any hearings. ${ }^{35}$ Public participation actually begins to some degree on the local level, since applicants must first satisfy local regulatory requirements prior to BEP action.

Under the state's Public Utilities taw, ${ }^{36}$ electric utilities also must obtain a Certificate of Public Convenience and Necessity from the Public Utilities Commission (PIJC) for construction of power plants capable of generating over 1,000 megawatts or for transmission lines which can carry over 125 kilovolts. Utilities have the power of emfneul domain, cubjest to the approval. of the PUC. However, residential homes cannot be taken through condemnation aulluitity unlees approval. is granted by the state legislature. The law also grants the PUC authority for regulation and licensing of natural gas pipelines within the state.

Under the Land Use Regulation Commission Law, ${ }^{37}$ the state regulates all J.and use activity in Maine's extensive unorganized territory (5I percent of the state's total land area). ${ }^{38}$ This includes all 1 and which is not within the boundaries of an organized town, city or Indian Reservation. In these. areas, the state cxercises planning, coning and subdivision conliuls. A permit. is required from the Land Use Commission prior to any consliuction: If BEP approves the proposed construction, the law's hearing requirement may be waived. If the PUC approves an application for utilities, the Land Use Commission may only place condltions on the use, but may not prohibit it. The Commission must adopt a land use plan delinenting proper use of resources and land use districts and standards which are consistent with the plati. Three bypes nf districts are specified: (1) protection districts, where development would be a threat (e.g., floodplains); (2) management districts, primarily for 
agriculture or forestry; and (3) development districts, for industrial and rẹsidential uses. Land use standards are designed to reduce pollution; protect. scenic features, and incorporate transportation planning and traffic safety.

The Coastal Wetlands Act requires that a permit be obtained from BEP, as well as fxom the appropriate municipality before commencement of any construction activities in a coastal wetland. 39 This power may be delegated to municipalities having appropriate review bodies and procedures. BEP or the municipality can prohibit proposed uses of wetlands which threaten public safety, adversely affect adjoining landowners, or damage wildlife or fisheries.

The Act Relating to Dredging, Filling or Otherwise Altering of Rivers, Streams and Brooks requires a permit from the Environmental Protection Commissioner for such activities. ${ }^{40}$ Criteria equivalent to those of the Wetlands program are employed.

The Flnod Disaster Protection Act makes available flood insurance from federal HUD for those localities which have land use plans restricting floodplain development. ${ }^{41}$ Premiıms are predicated on varying risks based on specific land use measures taken.

The Shoreland Zoning Law requires communities to adopt zoning and subdivision controls for land within 250 feet of any pond (over 10 acres), river or body of salt water in order to protect wildife, control building sites and preserve shoreline cover. ${ }^{42}$ Local controls must be at least as strict as state-proposed ordinances. If communities do not adopt zoning laws pursuant to this statute, or if BEP and the Land Use Commission judge local laws to be too woak, these authorities may impose state controls. 
The Act for a State Register of Critical Areas requires the State Planning office to inventory important

"areas containing or potentially containing plant and animal life or geological features worthy of preservation in their natural condition, or other natural features of significant scenic, scientific or historical value." 43

When the inventory is completed, localities will be required to develop plans for protection of the designated areas. The act establishes the Maine Critical Areas Advisory Board to assist the State Planning office in identifying critical areas and coordinating their use and protection. Under Maine's Zoning Enabling Law, ${ }^{44}$ real estate used by a utility company is exempted from municipal ordinances. Specific determinations are made by the PUC based on the doctrine of reasonable necessity for public welfare and convenience.

Maine was one of the first three states in the U.S. to qualify for grants under the 1972 federal Coastal Zone Management Act. Initial state projects have been divided into three elements: (1) extensive technical analysis of coastal areas, including mapping, inventory and planning; (2) study of the effects of development and other actions on the ecological, physical, and historic characteristics of the coastal area; and (3) a citizen participation program, including public opinion polls. 45

\section{Pollution Control Iaws}

Another response to the various proposals for oil facilities in Maine, the 0il Discharge and Pollution Prevention Control. Act was enacted to preserve the recreational and fishing uses and natural amenlites of lhe slate's coastline and estuaries from the dangers of spills which can occur during transfer of oil between vessels, and between vessels and onshore facilities. ${ }^{46}$ The statute prohibits discharge of oil in cuistal waters, on beaches, tidal flats 
and adjoining lands that drain into coastal waters. It applies to oil. terminals, deepwater ports, and associated facilities. Under this law, BEP is granted powers j.n an area up to 12 miles from Maine's coastline. BEP lịcenses oil terminal facilities annually and can regulate the operation and inspection of facilities, removal of oil (which must be done immediately by the offending party), and safety and operations of vessels. All licensees must pay an annual fee based on $\$ .005$ for each barrel of nil transferred. This money is credited to the Maine Coastal Protection Fund, to be used for clean-up costs and damages. The Fund is maintained at $\$ 4$ million. (A similar law has recently been adopted in New Jersey.)

The Protection and Improvement of Waters Law regulates discharges into state waters and requires a license before any pollutant is so disposed. 47 licensees must treat their effluent discharges with the best practicable treatment given the technology available. BEP can issue orders to end violations, with subsequent enforcement, if necessary, by the Maine Attorney General. However, the Attorney General may institute injunction proceedings independent of BEP for civil or criminal actions under the law.

The state's Protection and Improvement of Air Law requires a license for operation of any source of aịr contamination. 48

*Under the Outer Continental Shelf Lands Act, the federal government claims jurisdiction over lands beyond three miles from the coastline. Under the Federal Water Pollution Control Act of 1972, owners of any offshore facility must report any discharge of oil in United States waters. Under these circumstances, the President may declare an emergency and is to prepare a national contingency plan to remove the spilled oil.49 Thus, Maine's law may be in conflict with federal law. A Supreme Court decision -- U,S. v. Maine -- has vested exclusive ownership of the ocs in the federal. government, outside the three-mile limit. States bordering these areas are not entitied to any share of the sizeable leasing revenues which oil companies pay for exploration rights. 50 
The State Energy Resources Act, amended in 1974 and again in 1975, provides for long-range planning.to prevent energy shortages in Maine and to promote use of new sources of energy. 51 The statute's two major goals are conservation of natural resources and environmental protection. The act established the office of Energy Resources (OER) in the executive branch and an Energy Resources Advi.sory Council to assist.in. formulating an energy plan. OER is required to prepare a comprehensive state energy resources plan, to include analysis of Maine's supplies of and demand for energy, and to devise a state energy policy to meet the needs defined in the energy plan. The office can accept federal and private funds to be deposited in the Maine Energy Resources Development Fund for energy research and development activities.

Maine's Oil and Gas Conservation and Development Control Act prohibits waste of these critical commodities, defined as uncontrolled discharge, production in excess of reasonable market demand, inefficient storage, and placing of wells so as to cause any decrease in recovery. 52 The law applies to all state lands, including those on the continental shelf. A BEP certificate is required to transport oil or gas through the state's offshore waters, and a certificate of compliance from the owners of a well or refinery is needed before the owner of a pipeline can connect it to the facility. Permits are also required prior to all drilling activites. BEP may require performance bonds from those who produce, store, transport or refine crude oil or gas, and may also require liability insurance to indemnify fishermen and riparian owners for damages caused by pollution and waste. Fines are established for violations of the statute's regulations, drilling without a permit, or keeping false records. 
A nuclear moratorium citizen initiative drive was underway in Maine in 1976, sponsored by a group called Safe Power for Maine. To. succeed, the initiative must obtain 36,395 signatures; once this occurs, the group intends to petition the legislature to consider a nuclear moratorium. If rejected by the legislature, the question would then be put to the voters in a ballot referendum. 53

Conclusions

Maine has an impressive array of laws to regulate various activities * -including construction of energy facilities -- which have a potentially negative impact on its environment and land use patterns. Its Site Location of Development. Law of 1.970, while not devoted exclusively to energy facility siting, is the state's principal statute governing all major development, including siting of most energy facilitjes, and was initiated in part as a response to pressures for oj.1 development.

As in many states, Maine's siting law, though admirable for its coordinative powers and overview perspective, is a reactive mechanism which still leaves siting initiatives to utility companies, rather than to the state government. The siting law does not address issues of energy supply and demand, although this gap was filjed to some degree by passage of the State Energy Resources Act. Morenver, the Maine Siting Statute does not include analysis of alternative sites or alternative power sources as does New York's siting law, for example. The degree of public participation in the Maine siting procedure depends very much on decisions of the Board of Environmental Protection, a.though the law does afford opportunity for early local notification.

\footnotetext{
* Maine is one of only four states in the ration to have a law banning non-returnable beverage containers; the others are Vermont, Michigan and Oregon.
} 
Maine's siting law has been in existence for six years without substantial changes in its provisions. It is thus the oldest and most comprehensive of such laws among the six New England states. Although this perhaps indicates a degree of success, it might now be desirable to add specific energy criteria to the overall siting process.

\section{Laws Affecting Energy Facjlity Siting in Massachusetts}

Prior to enactment of a new state statute in 1973, the cities and towns of Massachusetts retained complete authority over approval of all energy facility siting. This situation changed with major legislatinn onactod by the General Court (the state legislature) in December 1973, to be effective on December 31 , 1974, In which serong state-level decision-making powers were introduced for the first time. Thrọgh subsequent amendments to this act, all major new energy facilities in Massachusetts have been brought under the purview of state decision-makers, with local veto power being maintained for oil facilities. This has made the Massachusetts approach one of the most comprehensive in the entire Northeast.

\section{State Control of. Energy Facility Siting}

The Energy Facilities Site Evaluation Act was the result of a twn-year study by the Massachusetts Flectric Power Plant Siting Commission, which was created by law in 1.971 . to examine the regulatory procedures of the Commonwealth regarding siting and operation of power plants and transmission lines. In 1974, after passage of the new state law, the Commission concluded that natural gas facilities also should be brought under the scope of the same art; this was accomplished by legislation in the same year. The jurisdiction of the act was broadened in 1975 to cover oil facilities, including oil refineries, storage terminals containing a minimum of 500,000 barrels of nil or refined 
oil products, and new oil pipelines longer than one mile. ${ }^{54}$ Under legislation adopted in 1976, the Commission's authority was broadened to consider the total energy needs of the state and to study various forms of energy expansion, with emphasis on offshore development. Membership on the Commission was jncreased to include the President of the Massachusetts Building and Construction. Trades Council (AFL-CIO) and the President of the Greater Boston Chamber of Commerce, or their designees 55 (see note below).

The act vested overall regulatory and coordinative authority in the new nine-member Energy Facilities Siting Council, comprised of the Secretaries of Administration and Finance, Consumer Affairs, Environmental Affairs and Manpower Affairs, plus five public members appcinted for three-year terms by the Governor. These public members must have experience in specifically designated fields, one as a registered professional engineer, one in conservation and protection of the environment, and one each in the activities of the electric power, gas and oil industries. The three industry specialists have only one cumulative vote, which may be exercised only on matters relating to their respective industries. Thus Council membership in Massachusetts strikes a balance between public and private sector representation; in contrast with New Hampshire's wholly state agency membership and Maine"s wholly private sector membership. The Council Chairman is named by the Governor.*

* Legislation under consideration in 1976 would also have broadened Council membership to include legislators (2 Representatives and 2 Senators) and a labor representative appointed from a list of five names submitted by the Massachusetts State Labor Council, AFL-CIO. This legislation passed the joint Government Regulations Committee and was sent to the House Ways and Means Committee. However, due to strong pressure from the Chamber of Commerce and the Massachusetts Building and Construction Trades Council (AFL-CIO) to spur nuclear power plant construction, amendments were adopted to add representatives of the Chamber of Commerce and the construction trades union. The printipals behind this thrust were Joseph Fitzpatrick of the Boston Chamber of Commerce and John Davoren, former Secretary of State who was defeated for re-election in 1975. Mr. Davoren is employed by the Massachusetts Building and Construction Trades Council. Proposed amendments to allow industry represcntatives on the Council to vote on all matters before it were defeated.56 
The Council is authorized to require and approve the following:

-Forecasts of demand for gas and electricity over 5 and 10 year periods respectively, and planned actions with respect to proposed oil facilities. No state agency may issue a permit until such demand forecasts have been approved by the Council.

- Notice of intention to construct an oil refinery, to be received at least two years in advance (one year in advance for other oil entities). This notice must include a complete description of the need for the facility in terms of meeting defined demands, identification of alternatives to the proposal, and analysis of its environmental impacts (land use, water, air, solid waste, ncise). No oil facility may be constructed until the Council has approved it.

In addition to this required notification process, Massachusetts has a unique provisiun establishing an appeal process whereby an applicant can petition the Energy Facilities Siting Council for a Certificate of Environmental Impact and Public Need. Such a request can be filed if:

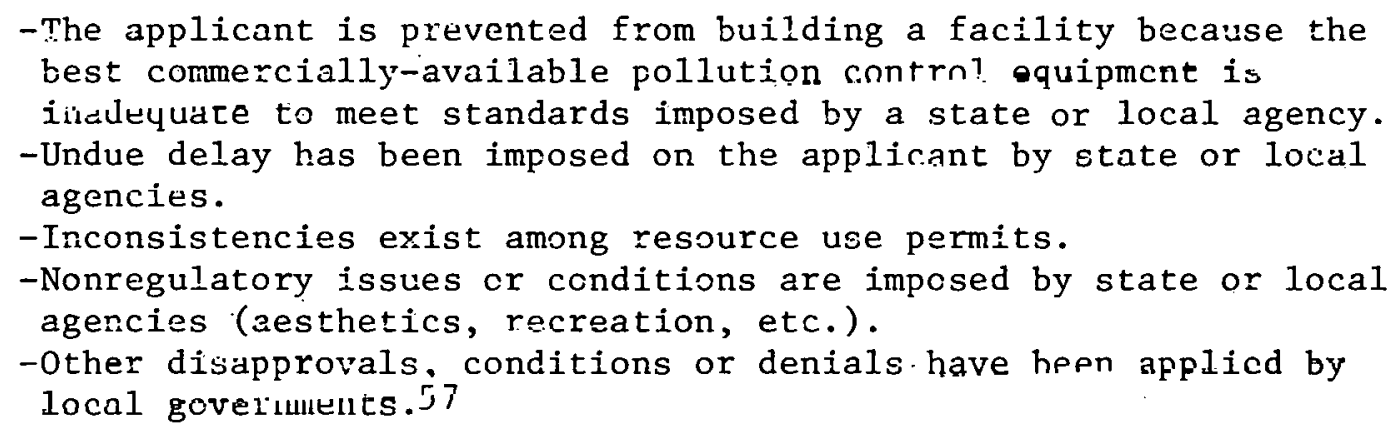
Granting of relief by the Council ronstitutca a comblete override of $\varepsilon$ tatc or local agcrcy rejection of any permit or lirenso ucucogaty lu cunstruct tacilities covered by the act. However, with specific regard to oil facilities, zoning laws already in effect on the date when a notice of intention was filed cannot be overriden by the Council. 58 This exception may be a result nf the o11 refinery controversies in New Hampshire and Maine.

Public hearings are required at carh step Laken under the act: longrange forecasts of electric power and gas peeds, notice of intention to construct an energy facility, a petition for a Certificate of Environmental 
Impact and Public Need, and application for a certificate under the National Pollution Discharge Elimination System (NPDES) of the Federal Water Pollution Control Act of 1972 .

The Council is required to make determinations within six months of receipt of an application for a Certificate cf Environmental Impact and Public Need. It must approve or deny long-range forecasts within 12 months, and act on a notice of intention to construct an sil refinery within 24 months and on other types of oil facilities within 12 months.

A fee system has been designed to cover most ccsts of operating the program. Filing fees for Certificates of Environmental Impact and Public Need may not exceed $\$ 25,000$; long-range forecast fees for power plant facilities may not exceed $\$ 400,000$, with each applicant being assessed a proportionate amount in relation to total $\mathrm{kw}$-hour sales within the Commonwealth; a maximum of $\$ 125,000$ may be required from gas companies, based on their proportion of gas revenues within the Commonwealth. For a notice of intention to construct oil facilities, a maximum of $\$ 400,000$ may be charged, based on expected capital investment:

The Council shares some of its regulatory power with the Department of Public Utilities (DPU) which, in addition to rate setting and other regulatory powers, can institute use of the power of eminent domain for energy facilities. The DPU also provides technical support to the Council. The Council, however, has final decision-making authority regarding evaluation of utility forecasts and approva1 of proposed energy facilities covered by the act. A response to ocs drilling proposals is contained in a 1976 Amendment to petition the Council for the right to exercise the power of eminent domain with respect to oil pipelines. 59

A measure enacted in August, 1975 requires a public referendum regarding 
attitudes toward oil refineries and deepwater ports in the Commonwealth. This issue was on the official state ballct in November, $1976 .^{60}$ The question was stated in this manner:

Shall the General Court enact legislation authorizing the construction of an oil refinery and a deepwater port, subject to the approval of those communities directly affected and any reservations that the General Court may prescribe?

The 1975 act further states:

If a majority of said votes is in the affirmative, it shall be deemed and taken to be the will of the people that the General Court shall enact legislation authorizing the construction of an oil refinery and a deepwater porr, and if a majority of said votes is in the negative, it shal] he depmed nnd talren to be the will of the people that the General Court shall not enact said legislation.

This referendum was approved by a margin of almost two to one. ${ }^{61}$ However, local veto power over oil facilities is still permitted. Now that the legislature may move forward with some kind of deepwater port legislation, it is significant that the Energy Facilities Site Evaluation Act does not appear to cover deepwater port facilities. This leaves the state without a coordinated legal and institutional structure or process vested with permit authority for such facilities. Since the referendum was approved, the state will have to rely upon numerous air, water and land regulatory statutes as well as associated federal statutes, at least until a more centralized process is developed for deepwater ports. In 1974, the state courts held that the Massachusetts Port Authority (Massport), which could build and operate a deepwater port facility, was subject to the authority of the Massachusette Environmental Protection Act (MEPA): This ronld not apply to private sector development of a deepwater port, however. ${ }^{62}$ oil refineries are covered under the Energy Facilities Site Evaluation Act (as amended). 
In another referendum on the ballot in November 1976, voters rejected an initiative measure for public-owned power plants via the creation of a public power authority. Public power will, however, go forward on a more limited basis under the recently established Massachusetts Municipal Wholesale Electric Company (MMWE), the state's first public power corporation. MMWEC is the agent for 25 municipal electric systems, providing them with assistance in making leng-range energy supply studies; in obtaining power from the New England Power Pool; and in arranging financing for municipal electric facilities. MMNEC's ability to issue tax-exempt revenue bonds enables it to finance its own generating facilities, the first of which is planned for surplus property at Westcver Air Force Base. MMWEC's basic purpose is to keep the cost of electricity down through competition with private utilities. 63 Environmental Protection and Pollution Control

Under the Massachusetts Environmental Protection Act (MEPA), ${ }^{64}$ it is the pelicy of the Commonwealth to preserve its environmental resources and promote the public welfare by mandating all state agencies to determine the environmental impact of their respective activities and to publish their findings in writing for public review. This must be accomplished before work can commence. Permits for private sector activities require preparation of an environmental impact report, though no funds of the Commonwealth are to be expended.

Massachusetts has a large coastal area; its Coastal Zone Maragement program extends 1,200 miles and encompasses 87 coastal communities. Several waterrelated statutes reflect this prominent geographical feature. These laws. $\because . .:$ bear directly on energy facility siting and constitute important criteria for approvals under the state's Energy Facilities Site Evaluation Act. 
The Clean Water Act regulates discharge of pollutants into state waters through management of a permit system. ${ }^{65}$ The Division of Nater Pollution Control licenses terminals for loading and unloading of petroleum products, as well as for disposal of hazardous waste substances. Those found responsible for oil spills are assessed the cost of restoration and are subject to fines or imprisonment if appropriate.

The Clean Water Act also provides for the Department of Natural Resources (DNR) to license activities for extraction of mineral resources in Massachusetts' coastal waters. After a lease request has been filed, DNR can take no final action until it has obtaincd information as to the quantity, quality and location of the resources, and the risk to marine and other natural resources. The Director establishes charges and fees for such licenses and leases. $\Lambda \mathrm{n}$ environmental impact report must be filed, and a public hearing must be held with notice given to each city and town bordering on the coastal waters of the Commonwealth. These stipulations work in tandem with several federal laws governing activity in coastal waters, especially Army Corps of Engineers permits under the Rivers and Harbor Act of 1899. 66

'l'he Discharge of Petroleum Products Law authorizes the Department of public Works (DP.i) to regulate and 1icense structures below the highwater mark and to license construction of underwater pipelines and cables. DPW may "require any pipeline to be relocated." Federal government activities are exempt from this statute. 67

Pursuant to the Scenic and Recreational Rivers and Streams Act, DNR Illdy adopt or amend regulations restricting or prohibiting activities on the scenic and recreational waters of the Commonwealth. This act could restrict use of certain bodies of water as cooling agents for power plinnts. ${ }^{68}$ DNR. 
maintains additional controls under the Protection of Inland Wetlands Jaw, ${ }^{69}$ Activities in coastal wetlands are regulated by DNR under the Protection of Coastal Wetlands Act. ${ }^{70}$ The goal of this statute is to protect salt marshes and contiguous freshwater marshes and tidal flats, and to prevent coastal erosion. The Coastal Fill and Dredge Act confers further regulatory authority upon DNR. ${ }^{71}$,

Both the Coastal and Inland Wetlands Acts lack permit powers. Thus, it appears that DNR has 1imited authority to prevent proposed activity by an applicant unless it falls under the jurisdiction of the Coastal Fjill and Dredge Act, which does provide for permits prior to a proposed activity. However, even this may be inadequate since DNR can impose conditions under the Coastal Fill and Dredge Act, but cannot deny a permit. ${ }^{72}$

Local and state Departments of Health share jurisdiction under the Air Pollution Act. ${ }^{73}$ In a. 1974 energy-oriented amendment to this act, immediate economic relief, was sought from the spiraling costs of energy due to the high cost of fuels. This amendment, considered an emergency measure, directed the Massachusetts Department of Public Health (DPH) to review the state's ambient air quality standards and implementation plans in order to minimize their economic impacts. Initial steps involved postponement of dates for attaining standards to the latest dates permitted by federal law. The amendment also directed consideration of fuel switching, stack heat and varjatjons in plant operations in lieu of existing controls on sulfur or ash content of fuels or emissions, as long as ambient air quality standards could be achieved in that manner.

Energy Policy Coordination

Within the executive branch, the Governor's Resource Mangement Policy Council. (RMPC) also could serve a substantive coordinating role in energy 
policy formulation. ${ }^{74}$ The RMPC is comprised of eight of the ten Cabinet members. It is broadly charged with overseeing development and coordination of resource management policies and programs of the Commonwealth, and specifically directed by the Governor to coordinate and direct the state's participation in coastal zone management, air and water quality, land use and rural development programs, and to report its recommendations periodically. This policy-oriented body, similar in some ways to New Jersey's Cabinet Energy Committee, could make a significant contribution to the multi-layered energy management issue. Conclusi.ons

Statutory provision for energy faciljty siting in Massachusetts has been in effect only since the beginning of 1975. Although comprehensive, it is relatively new and thus largely untested. The Energy Facilities Site Evaluation Act applies to most energy faciljties, but does not appear to cover deepwater ports.

The Massachusetts siting act is interesting in several respects. First, while it affords state override power on local decisions for electric and gas facilities, it does not grant these powers for oil facilities when local zoning laws are in effect prior to the proposal to construct an oil facility. This feature is similar to New Hampshire's law. A second notable feature is the Siting Council."s authority to waive standards and grant approval. for a varlety of reasons, including:

"the electric, gas or oil company believes there are inconsistencies among resource use permits... or ...believes that a non-regulatory issue or condition has been raiscd or imposed by such state or loc.a1. agencies such as hut. not. limited to apsthetics and rerreatinn...."

This latter provision may permit the Council to make potentially arbitrary interpretations. This compromise may reflect the highly complex nature of 
writing and administering energy facility siting statutes, however.

A third notable feature of the Massachusetts siting act is the composition of the Siting Council, a composite of public and private sector representatives. This contrasts with New Hampshire's wholly state agency membership and Maine's wholly private sector membership. When these laws have received the test of time, it will be interesting to determine if one structure proves more effective than the others, although such comparisons are often difficult because of inherent differences in each state. Finally, the Massachusetts siting mechanism takes a reactive regulatory posture akin to the institutional procedures of most states, including all six in the New England region.

In light of the controversy regarding federal. oil and gas leases in the Outer Continental Shelf, it is interesting to note the requirement in the Massachusetts clean Water Act that, prior to state leasing, information must be obtained as to quantity, quality and location of such resources and the risk to marine and other natural resources. This is the reverse of the federal procedure, in which leases are granted prior to obtaining knowledge of resource quantities.

\section{Laws Affecting Energy Facility Siting in New Hampshire}

In 1973, New Hampshire experienced an energy facility siting controversy which received widespread national attention. In microcosm, this conflict is illustrative of the siting dilemma faced by many states and localities. The issue involved a proposal by Olympic Refineries, then controlled by the late Aristotle Onassis, to construct a large oil refinery on the coast at Durham, home of the University of New Hampshire. ${ }^{75}$ (New Hampshire has a relatively short coast, some 15 miles in total.) This refinery proposal was rejected by a vote of the residents of Durham in a special referendum, and legislation proposed for a state override of this local decision failed in the state' 
legislature, despite its sponsorship and strong support by Governor Meldrim Thomson. 76 Under subsequent New Hampshire 1.aw, oil refineries now require explicit local site approval, with state override specifically prohibited. 77 In another energy facility siting controversy on-going since 1969, a proposal to build two 1,150 megawatt nuclear power plants in the marshes at. Seabrook, near the Atlantic Ocean, has been turned back by the U.S. Environmental Protection Agency (EPA). In a reversal of its original decision, EPA in November 1976 revoked its approval of the $\$ 2$ billion-plus plant's cooling system. Although the project has the enthusiastic backing of Governor Thomson, the citizens of Seabrook in a non-binding November 1976 referendum voted 768 to 632 against the nuclear plant.

This controversy points up the sometimes conflicting requirements of governmental agencies. At Seabrook, EPA opposes an open cooling system which would draw water from the ocean. However, the Nuclear Regulatory Commission's (NRC) building permit granted in June 1976 specifically forbids use of cooling towers on this site as an alternative. EPA objections focus on the inadequacy of once-through cooling to "protect the fragile marine environment and assure the protection and propagation of...shellfish, fish and wildlife." ${ }^{3}$ NRC's objections are in part related to cost/benefit factors which they feel are unfavorable with use of the closed-cycle cooling towers. Since EPA approval is part of the NRC's licensing requirements, the plant is stymied, although more hearings are expected in 1977. The original Seabrook proposal in 1969 was for a single 860 megawatt unit-- now vastly expanded to a total of 2,300 megawatts. This compares to the single 540 megawatt Vermont Yankee plant

* The utility, the Public Service Company of New Hampshire, had planned to spend $\$ 165$ million on tunnels 1.5 miles long and 22 feet in diameter to bring the water in and out of the plant's once-through cooling system. 79 
across the Connecticut River on New Hampshire's western border: 80 .

In view of the controversy over the Durham and Seabrook proposals for New Hampshire's meager coastline, reasons for this site selection require further exploration. This is especially relevant in that the Seabrook facility would ship a substantial amount of its power out of the state. One clue is given in a site survey done for the utility in the late 1960's, which noted: "The site shall preferably be in New Hampshire due to public relations and tax considerations." 81

Power Plant Siting

In 1971, the Flectric Power Plant, Transmission Siting and Construction Procedure Act became law. Its purpose was to balance adverse environmental impacts against the need for new sources of power. ${ }^{82}$ Under this statute, site and facility certification is required prior to construction of power plants and transmission lines. Economic, environmental and technir.al factors are to be considered jointly under the act. The law regulates bulk power facilities, defined as electric generating stations and associated facilities larger than 50 megawatts, plus electric transmission lines carrying over 1.00 kilovolts over a new route more than 10 miles in length.

The act is administered by the Bulk Power Si.te Evaluation Committee (BPSEC), which has ultimate authority over siting and related activities. It is comprised of the directors of various state agencies: environment, planning, public utilities, economic development, radiation control, air pollution, parks, water supply and pollution, natural resources, and health and we? fare.

The BPSEC has two major functions. The first is to review and comment on long-range plans for utility expansion. In this role, BPSEC conducts hearings 
on any new plant site, which must be identified in the utility's plans at least five years in advance of construction. The Committee's second major function is to hold joint hearings with the Public Utilities Commission (PUC) upon receipt of an application for certification of a specific site or facility. The PUC transmits the companies' long-range site plans to BPSEC, which considers their environmental. impacts, including effects on aesthetics, historic sites, air and water quality, the natural environment, public health and safety. It sends its findings to the PUC, which then weighs the need for the electric power in view of present and future demands, adverse effects on system stability, and economic factors. Based on BPSEC findings, the PUC decides whether to approve the proposed site.

Either agency can veto a proposed facillity, and its negative decision is binding on the other. In fact, any state agency with jurisdiction over any aspect of the development may negate the project for justifiable cause. Neither BPSEC nor the PUC has authority to override these state agencies. Al.though the applicant must mect the permit requirements of other state agencies, it need only apply to a single agency in a "one-stop process". Two hearing procedures are required, one for long-range planning, the other for specific site proposals. BPSEC must publish notice of hearings in the area of each proposed site included in the utilities' long-range plans. For specific site proposals, PUC and BPSEC hold joint public hearings in the county where the proposed facility is to be located. The first hearing is informational in nature, with the utility presenting data to the public. The subsequent, hearing is conducted as an adversary proceeding, with an Assistant Attorney General. acting as counsel for the public to represent their interests for both adequate power and for environmental protection. 
Utilities' long-range plans must cover all power plants and transmission lines to be constructed within five years. These plans must include such details as routes of transmission lines, environmental impacts, relation of proposed site to existing ones, and cooperative efforts planned with state agencies. BPSEC decides if these proposed sites should be included in the fiveyear inventory, a step which must take place at least two years before commencement of construction. PUC and BPSEC must approve specific sites based on a "comprehensive planning process" which includes economic and future demand factors. The PUC is authorized to exercise the power of eminent domain, if necessary, for site acquisition. Thus, provided BPSEC approves a siting permit and PUC implements eminent domain proceedings, the state has authority to override local wishes for power plant siting ${ }^{83}$ (again, a sharp contrast from the situation with respect to oil refineries).

Under New Hamphire's Public Utilities Law, if utilities wish to take land for intrastate transmission lines or pipelines and cannot secure an agreement from the owner, the PUC must hold a hearing and may then approve the taking. The PUC must approve construction of any facility, transmission line or pipeline in a locality where a utility is not currently doing business, and it must approve a line to a consumer over 1,000 feet from an existing line. In addition, the PUC must issue a permit before a utility can construct transmission lines or pipelines over or under state lands or waters. 84

The state's Peaceful Uses of Atomic Energy Law regulates nuclear materials in a manner consistent with the U.S. Atomic Energy Act. Rule-making powers in this area are delegated to several state agencies:

Department of Health and Welfare - hazards to public safety Department of Labor - working conditions Department of Public Works and Highways - transportation of nuclear materials on state highways 
Public Utilities Commission - transportation of nuclear materjals by common carrier

Council on Resources and Development - hazards to natural resources. 85

Siting of oil and Gas Facilities

In. early 1974, the state adopted an Act Relative to Energy Facility

Evaluation, Siting, Construction and Operations. This legislation established a new decision mechanism for siting of oil refineries and other petroleumrelated facilities, including deepwater ports and natural gas facilities. ${ }^{86}$

The decision process is similar to that of the previously-discussed law governing power plants, with one major exceptlon: Juchl guverimululs are given veto power over refinery siting. The same agencies are represented on the inter-agency group, here entitled the Fnergy Facility Evaluation Committee (EFEC). 87 It can review, approve, monitor and enforce conditions relative to planning, siting, construction and operation of oil reflnerfes and related energy facilities.

This law was enacted after the 1973 oil refinery siting controversy in Durham. It was initiated by a variety of groups, including private sector refinery developers, environmental interest groups, and the Attorney General's office. ${ }^{88}$ Principal features of the law are as follows:

-A single state permit is required to construct and operate a facility. This permit must be either issued or denied by EFEC within 14 months of receipt of an application. -A11. state agencies with authority to grant permits are represented on EFE.C, which has broad powers with regard to issuance of permits. and monitoring and enforcement of compliance with such permits. -Application requirements allow EFEC to enter into the planning process for refinery development at an early stage, in order to facilitate development of environmentally-sound operation and siting critteria. -The state, through EFEC, conducts all hearings pursuant to the law. Hearing processes are designed to provide information to FFEC from all interested segments, jncluding state agencies, the public and the applicant.

-All relevant environmental and economic factors must be considered by EFEC, which has the power to issue cease and desist orders and to take appropriate action in Superior Court to enforce compliance with the act. 89 
The principal distinctive feature in oil refinery siting is the state requirement that sites selected for such facilities receive local approval by majority vote in a town, or by public referendum or two-thirds vote of the governing body in a city. This mechanism was established by a 1974 amendment to the Powers and Duties of Towns Law, originally enacted in 1935.90 This feature of the siting law, in sharp contrast to provisions for power plant siting, was enacted the same year as passage of the legislation governing EFEC permits for oil refinery siting. As an alternative, localities may vote to support siting of refinery facilities in their jurisdiction, allowing EFEC to carry out specific evaluations of proposed facilities.

Although only one application is required under the siting act, this application must satisfy the requirements of other state agencies having jurisdiction over any aspect of the construction or operation of the proposed facility. This includes air, water, noise, land use standards, and so on. As is the case with power plant siting, any state agency vested with authority to regulate any aspect of construction or operation of the proposed facility may deny authorization for the development, with supportable justification. Denial by any one such agency negates an applicant's opportunity to obtain a permit from EFEC, which like BPSEC for power plant siting does not have authority to override another state agency's regulatory authority. ${ }^{91}$

Provisions for public participation in siting of oil and gas facilities are basically the same as those for power plant siting, with an initial public information hearing held in the county in which the facility is proposed. Subsequent hearings, as adversary proceedings, afford opportunity for both oral and written testimony by interested parties. Again an Assistant. Attorney General serves as counsel for the public. The public is afforded access to all EFEC 
records, files and reports. The siting act does not provide for long-range planning and site inventory, however, as does the law governing power plant siting.

\section{Pollution Control and Environmental Protection}

The Water Pollution Act requires that a permit be obtained before discharging pollutants into waterways of New Hampshire. A permit is also required, under this law, for dredging, filling, or construction in or on the borders of the surface waters of the state, including wetlands. 92

Under New Hampshirc's Tidal Waters Act, a permit must be obtained from the Water Resources Board for construction activities in or adjacent to state waters. 93 The 1aw's purpose is to prevent harm to wildlife, prevent obstruction of commerce and recreation, maintain stream channels and ensure their ability to absorb flood waters. If a decision is appealed to the courts under this 1 aw, and if the court affirms the state's action, the state may then have a perpetual negative easement rather than a fee simple claim to the land, such that it cannot be dredged. The state may also purchase the land.

The Air Pollution Control Act established a State Air Pollution Control Agency within the Department of Health and Welfare and an Air Pollution Contro] Commission composed of representatives of industry, health, recreation groups and the general public. ${ }^{94}$ The Commission is authorized to conduct hearings and investigations, to advise the Agency on policies and plans, and to issue rules and regulations -- effective after public hearings -- to control. air pollution. The Agency is authorized to administer a permit system for construction and operation of any device which contributes to air nollution. It may delay or prevent construction. of any facility which would cause violations of the ambient air standards established by the New Hampshire implementation plan 
promulgated under the federal Clean Air Act. The Agency may issue abatement orders to violators, although provision is made for variances in cases of economic hardship.

The Oil Spillage in Public Waters Act provides a procedure for clean-up after spills. This law applies to pipelines, refineries, ports, terminals, vessels and any other facility which transfers or stores oil or its byproducts.95 New Hampshire claims title over its waters and submerged lands for 200 miles from the roastline, a claim which could cause conflict with federal and international 1.aw. The state's Water Supply and Pollution Control Commission implements a bond system and maintajns an emergency clean-up fund.

\section{Conclusions}

In New Hampshire's two siting laws, one governing power plants and associated transmission lines and the other regulating oil refineries and related facilities, broad siting powers are vested in the lead "one-stop" agency administering the particular law, although other state agencies may also have veto power over the proposed facility. New Hampshire, like many other states, has siting statutes which are reactive to utility company initiatives. In addition, no clear frame of reference is defined in the law to determine the state's overall energy needs, nor are impacts of facility development on local and/or regional infrastructure clearly defined. The power plant siting law does, however, provide for long-range planning of sites (albeit based on utility proposa].s). Public participation appears to be well served, especially in pre-hearing informational sessions and in the appointment of an Assistant Attorney General to serve as counsel for the public. Success of this latter feature, of course, depends very much on the individual's personal ability to confront the utility's attorneys in adversary proceedings. 
New Hampshire's 1973 controversy over the Durham oil refinery proposal resulted in a clear confrontation between local and. state authority over energy facility siting, and over the broader issues of land use and home rule. Local siting power was explicitly affirmed, at least as far as oil refineries are concerned, in a 1974 statutory amendment requiring such facilities to receive local approval. The state's coastline is relatively short, which tends to heighten public concern over its use. The incident in Durham is instructive because it focuses on the crux of the siting issue: 1ocal citizen determinations vs. state or regional perspectives. Both goals somehow must be served, and therein lies the difficult balancing act.

\section{Laws Affecting Energy Facility Siting in Rhode Island}

In 1974, the Rhode Island General Assembly enacted a unique law granting it the power of final approval or denial over the location and construction of oil. refineries and nuclear power plants; none can now be built without the legislature's explicit approval. 96 of the 11 states of the Northeast from Maine through Maryland, Rhode Island was the first to pass such a law; Vermont followed in 1975 (Vermont's law applies to nuclear power plants only). By early 1976, at least 28 states in the nation were considering some type of law to curtail nuclear power, although not necessarily through a complete moratorium. 97 At least 20 of these states were pursuing the citizen initiative process, 98 witnessed in California's June 8, 1976, referendum where voters rejected one form of proposted new nuclear controls. Of these 28 states across the country, Rhode Island lias the distinction of being the first to enact some form of nuclear restriction.

* In 1975, the General Assembly attempted tu broallen and clarify its powers pertaining to approval of these facilities. The discussion below of the Rhode Island Port Authority and Economic Development Corporation Act, which granted override powers to the General. Assembly prior to construction of oil refineries or nuclear plants, provides further information on this issue. 
Although comprehensive "one-stop" power plant siting legislation, including long-range planning, was proposed in Rhode Island in 1975, it was not enacted. 99 This left the state's Public Utilities Commission (PUC) as the principal siting authority. The PUC is vested with power to issue or deny Certificates of Public Necessity and Convenience for the location, construction, and operation of power plants and related. facilities, except nuclear power plants which require specific approval from the legislature. This feature of the law remains untested, since no nuclear plant (or oil refinery) has been. proposed in Rhode Island since its passage. ${ }^{100}$ The PUC also has jurisdiction over natural gas facilities.

Certificates are issued by the PUC after a hearing and after an applicant has demonstrated compliance with state and federal statutes pertaining to air and water pollution control and public health and safety. This includes approval from the Coastal Zone Management Council on facilities sited within its area of jurisdiction (concerning multiple-use development and ecological. compatibility as well as present and future land uses). The application procedures also include information on present and future energy supply and demand. Public participation is afforded through defined adversary hearing procedures, When testimony on the proposal may be presented by state agencies with jurisdiction over aspects of the development, local officials and interested citizens.

The PUC has the power to override local authority for site acquisition through the mechanism of eminent domain, if it finds that the proposal is for the benefit of the general public, is necessary for service, and will not interfere unduly with orderly regional and scenic development. 101 
However, the PUC does not have authority to override the decisions of other state agencies concerning negative impacts of the facility. Therefore, the process may be characterized as essentially composite in nature, with the PUC serving in a coordinating role. Port Development Authority and Refinery Siting

In order to attract new industries and thereby relieve unemployment, the state legislature in 1974 enacted the Rhode Island Port Authority and Economic Development Corporation Act. The public corporation named in the act is empowered to acquire and develop real and personal property to promote the state's economic development. Under this law, the public use designated by the Corporation is considered superior to any other use, and the Corporation has been given power to employ eminent domaln proceedings where necessary. Acquisition of land belonging to the state or any of its political subdivisions, however, requires consent of the party holding the land. Moreover, the Corporation's projects must conform with applicable comprehensive plans, zoning or other land use ordinances. 102

It was this law which granted the General Assembly fj.nal authority to approve or deny siting of any oil refinery or nuclear plant. However, the Corporation has authority to promote and develop plans for an oil refinery. 
Ambiguities relating to authority by the General Assembly over the corporation's oil refinery development plans remained unresolved as of late $1976 .{ }^{* 103}$

*In April 1975 the General Assembly amended this act to specify that all entities within the state, including the Corporation, required approval of the General Assembly for siting of oil refineries and nuclear power. plants. This amendment also broadened the General Assembly's authority over all plans for these facilities, not just final plans as originally specified. However, the amendment was vetoed in May 1976 by Governor Phillip W. Noel. In his veto message, the Governor indicated that he was in agreement with the legislature's role in approving or denying the facilities specified and the need to clarify certain sections of the law. However, he stated:

"Unfortunately, it is my opinion that this legislation will not allow the General Assembly to participate in these types of decisions in a meaningful way. This legislation contains many ambiguities that could well act to discourage potential developers. This legislation does not spell out precisely how the General Assembly will exercise its power of approval. Does the legislature intend that approval be by resolution or by statute? If it is intended that approval will be by statute then the use of the word 'exclusive' conflicts with the requirement that statutes of this state be submitted to the Governor for his signature. I do not believe that the General Assembly intends to abrogate the responsibility of several regulatory agencies which have a responsibility in this area. However, the language contained in this legislation can be construed to mean that the General Assembly will preempt these agencies in certain areas of heretofore delegated responsibilities.... I am further concerned that because of the ambiguities and the various ways in which this legislation can be interpreted that it will lead to extensive litigation which will not be in the best interests of the State of Rhode Island."104 
Rhode Island's coastal area is its most prominent geographical feature, and the state has several coastal and water protection laws which form part of the criteria upon which the PUC must base its decisions to approve or deny proposed energy facilities. The Coastal Zone Management Council (CZMC) administers the Waters and Navigation Law of 1971. In this role, the Council must take into consideration the possibility of multiple use development, ecological compatibility, present and planned uses and facilities, and overall development of the state. The Council's area of concern includes any operation "within, above or beneath the tidal water below the mean high water mark,... and to the extent of the state's jurisdiction in the territorial sea" (200 miles or I fathom in depth, whichever is greater). Activities specified under the Council's jurisdiction include:

- power plants;

- petroleum processing, handing, storage and transfer;

- mineral extraction;

- sewage treatment; and

- activities in intertidal salt marshes.

The Council äts jn an adviscry role, coordinating among various governmental. and private interests. It can, however, implement binding arbitration in any dispute between municipalities or state agencies involving the coastal region and its resources. 105 While there is no provision in the law for financing the Council's hearings or studies, it is authorized to accept federal funds and has received grants under the 1972 federal Coastal Zone Management Act. Pollution Control

Water pollution prevention in Rhode Island is the shared responsibility 
of the Division of Water Pollution Control and the Department of Health. Special provision is made for possible oil spills. State offjcials have authority to regulate "all methods employed...in any vessel or at any installation on land that serves as a storage or transfer facility for petroleum products. ${ }^{106}$ The Conservation of Marine Resources Act regulates transportation and deposit of any waste or dredge material within the territorial waters of the state. ${ }^{107}$ The Obstruction to Navigation Act grants powers to the Department of Natural Resources to regulate deposits of "mud, dirt and other substances in the public tide waters of the state."108

Laws protecting Freshwater Wetlands and Coastal Wetlands are similar in nature. 109 They require that approval be obtained from the Department of Natural Resources prior to undertaking various activities in these areas, including diversion of water or otherwise altering the character of the lands to be protected. State approvals may not be granted unless the governing body of a locality within whose borders the project lies also approves. 110 The constitutionality of the 1971 Freshwater Wetlands Law providing for state control over these lands was challenged in the courts and upheld by the Rhode Is 1.and Supreme Court on February 26, $1976 .^{111}$

Jnder Rhode Island's Clean Air Act, ${ }^{112}$ the state has the usual. enforcement powers with respect to air emissions. * These standards must also be considered by the PUC in reaching decisions on energy facility siting.

* In the case of Natural Resources Defense Council (NRDC) V. EPA in 1973, assessing Rhode Island's Clean Air Act, it was determined that to the extent that the statute allowed the State Director of the Department of Health to consider economic and social factors and technical feasibility in issuing abatement orders, the act was inconsistent with federal standards and EPA.must disapprove it. Pursuant to federal. law, provisions must also be made for revision of plans after a public hearing.113 (There was a similar finding in Massachusetts.) 
Rhode Island's Atomic Energy Commission was created by law in 1955 to conduct studies concerning statutory changes that may be required to control nuclear materials as by-products of operating nuclear facilities. The Commission is also directed to coordinate industrial and commercial uses of atomic energy and to cooperate with the federal AEC. ${ }^{114}$

The General Assembly has not enacted the comprehensive state land management bill proposed in 1975. This act would have had major ramifications for energy facility siting. 115

\section{Conclusions}

Rhode Island's General Assembly has been unable to enact proposed comprehensive energy facility siting legislation, and a broad state land management law which would have altered the process for making such determinations was defeated in the legislature. Thus, energy siting remains the purview of the Public Utilities Commission. This present PUC review mechanism does not afford the advantages of a siting authority with multi-jurisdictional membership such as exists in other states, wherein members' interdisciplinary backgrounds offer an opportunity for decision-making based on a wide range of institutional concerns.

The state's 1974 law granting the legislature power of final approval or denial on siting proposals for oil refineries and nuclear power plants remains untested, since no such proposals have emerged since the law's enactment. However, it is unclear whether the legjslature could override other state agency negative determinations (e.g., state wetlands requirements), or if it could modify an oil refinery or nuclear power plant proposal through a conditional approval.

Long-range energy planning, efferts on infrastructure, and basic state 
initiatives in site selection are not served very well under Rhode Island's current institutional mechanisms, although the innovative Rhode Island Port Authority and Economic Development Corporation can initiate ports and related energy development.

\section{Laws Affecting Energy Facility Siting in Vermont}

Vermont received attention in April. 1975, when it enacted legislation granting unique powers to the state.legislature to approve or prohibit construction of any proposed nuclear power plant within the state. ${ }^{* 116}$ of the 1]. states of the Northeast from Maine through Maryland, on.ly Vermont and Rhode Island had such laws as of September 1976.

\section{Legislative Control Over Nuclear Power Plant Siting}

Concern over nuclear power in general, exacerbated by the state's specific problems with the Vermont Yankee nuclear power plant (located at Vernon, Vermont) prompted passage of this legislation. This is Vermont's only operating nuclear power facility. The 1975 law requires the Public Service Board (PSB) to obtain explicit approval from the state legislature before issuing a Certificate of Public Good for construction of a nuclear power plant. ${ }^{117}$ This act was an amendment to the Vermont Public Service Law, which governs siting of power plants and transmission line corridors. This law has not actually been tested since its passage, as there have been no proposals to build any new nuclear facilities in Vermont.

The degree of legislative concern over the Vermont Yankee plant is evident not only in the 1975 decision to vest final nuclear siting approval in the legislature itself, but also in a related joint resolution introduced on

* As noted in the preceding section, Rhode Island's statute -- passed in 1974 -requires the legislature's approval prior to location and construction of oil refineries as well as nuclear power plants. 
February 27, 1976. Although this resolution was defeated in the House

Committee on Government Operations, it did have widespread support in the legislature, and its wording is indicative of legislators' concerns: ${ }^{118}$

"Whereas, the viability of nuclear energy as a power source of the future presents serious and substantial questions; and

Whereas the state of Vermont, through the emissions agreement reached between Vermont Yankee and the state prior to construction and through passage of H.1.27 during the last legislative session, has already expressed its concern about nuclear energy as a power source; and

Whereas, Vermont Yankee has a long history of problems which affect the safe operation of the plant including six major problems which have come to the attention of the Board of Health: plant;

(1) Wear and subsequent vibrations in the fuel rod channels at the

(2) Cracks in the collet housing;

(3) Inverted tubes in control rods used to control the plant's reactor;

(4) Inoperable hydraulic shock suppressors;

(5) The need to expand storage facilities for spent fuel at the p.lant, and

(6) The torus movement problem; and

Whereas, the recent changes approved by the Nuclear Regulatory Commission to allow Vermont Yankee to continue operation are operational responses to a structural problem; and

Whereas, the NRC has no review process whereby the state of Vermont. may address the changes in overall safety occasioned by the various problems at Vermont Yankee and the solutions apprnved by the NRC; and

Whereas, any costs incurred by the closing of Vermont Yankee including the costs of the shutdown, safety modifications and replacement power purchased, are the responsibility of the General. Electric Company and should be assumed by them, now therefore be it

Resolved by the Senate and House of Representatives:

That the Board of Health, the Public Service Board and the Water Resources Board are directed to take whatever action is required to require Vermont Yankee to cease operations pending correction of the plant's structural deficiencies; and be it further

Resolved that the General Assembly hereby expresses its disapproval of the decision by the NRC to allow Vermont Yankee to resume operation, and recommends that in the futurc the NRC establish a poliny of a thoroug! periodic review of safety factors in nuclear plants and encourage state participation in the review process; and be it further 
Resolved that the General Assembly hereby establishes a joint standing committee on nuclear energy, to be somposed of the House Committee on Government Operations and the Senate Committee on Energy, and that the Joint Committee on Nuclear Energy appoint two of its members from the House and two of its members from the Senate to the Nuclear Advisory Committee which will also consist of the Attorney General, the Chairman of the Public Service Board, the Commissioner of the Department of. Health, and the Secretary of the Agency of Environmental Conservation or their designees; and be it further

Resolved that Vermont Yankee shall not resume operations after a safety shutdown without first obtaining the approval of the Nuclear Advisory Committee." 119

The Vermont Yankee nuclear power plant gained further attention on July 21, 1976, when a federal court ruled that the earlier order granting its operating license must be returned to the U.S. Nuclear Regulatory Commission (NRC) for further consideration because the environmental impact of wastes produced at the plant had not been considered when the plant initially was granted its operating license. In a two-case decision, the court charged the NRC with being "arbitrary and capricious" in its past approvals of power plants, ordering it to review its prior approval of Vermont Yankee (and a plant at Midland, Michigan). In this review, the NRC was told to take into full consideration nuclear waste disposal and the alternative of energy conservation in lieu of constructing new power plants before approving any new nuclear power plants. In response to this court decision, the NRC announced on August 13, 1.976 that it would temporarily stop issuing construction permits and licenses for nuclear power plants to operate at full power until it. completed a study on the impact of nuclear waste disposal. The NRC announced that its report was expected by September $30,1976$.

An NRC spokesman said that although the 61 nuclear power plants in the U.S. that were already operating were not affected by the Vermont Yankee decisions, their licenses may be re-examined, Five nuclear plants scheduled 
to commence construction in Louisiana, Washington (two plants), Florida and Kansas were to have their permits delayed. ${ }^{120}$ However, the NRC moratorium has been 1ifted. As of early February 1977, construction or operation of any nuclear facilities had not been appreciably affected. This includes Vermont Yankee, which has had normal operation throughout the controversy. ${ }^{121}$ The matter; in early 1977, was again before the courts. ${ }^{122}$

Concern had been expressed by some, including the Natural Resources Defense Council, Inc. (NRDC), which initiated one of the suits against the NRC, that NRC's stated deadline of September 30 would make it virtually impossible to complete a thorough study of waste reprocessing and disposal. 123 Indeed, the study, 1ssued in early october 1976, was described by an NanC attorney as a "transparent device to escape the court's decision." 124 The U.S. Energy Research and Development Administration (ERDA), which by federal 1.aw 15 responsible tor answering the disposal question, currently is undertaking a multi-year program to $\bar{f}$ ind sites for burial of radioactive wastes. ERDA is studying salt beds and shale deposits throughout the country, but none of these studies were anywhere near complete by September 1976.125

Two days after the tederal court dccision was annuinced (un Inly 23, 1976), Vermont's Nuclear Advisory Board -- which oversees Vermont Yankee from the state perspective -- held a special. meeting to discuss the plant's recent accidental discharge of radioactive material, into the Connecticut River. 126 This latest incident and the federal court decision will have an obvious impact in Vermont, reinforcing the legislature's commitment to innovative state exercise of authority in the nuclear energy arema.

Regulation of production, manufacture and transportation of nuclear materials' is established under Vermont's Radiation Control Law of 1967, which 
requires a license from Agency of Environmental Conservation's Protection

Division.' 127

The Division has authority to impound nuclear materials in an

emergency.

Other Regulation of Power Plant Siting

Before it can issue a Certificate of Public Good for any power plant in Vermont, the Public Service Board (PSB) must consider certain criteria, including:

- that construction not unduly interfere with orderly development in the region;

- the facility is needed to meet present and future demand;

- the plant will not adversely affect system stability, reliability and economy factors;

- the plant will not have an undue adverse effect on aesthetics, historic sites, air and water purity, natural environment and public health and safety. 128

The PSB is comprised of three members appointed by the Governor: the Commissioner of the state's Public Service Department (Chairman) and two other members who serve on a part-time basis. T.t serves as the coordinating and decisjon-making body for purposes of fossil fuel power plant siting approval. or denial, and as the principal advisory agency to the legislature for purposes of permit approval or denial concerning nuclear power plants.

The PSB must approve all eminent domain takings by utilities. Public participation is provided through defined adversary hearing procedures, in which participating state agencies may testify on the proposal, along with local officials, regional planning bodies, and interested citizens. Although the PSB is empowered to use eminent domain proceedings to override local authority for purposes of site acruisition, it does not have override authority over state agency decisions concerning the facility. ${ }^{129}$ Monitoring and enforcement authority j.s retained by state agencies maintaining regulatory jurisdiction. 
The PSB also has jurisdiction over construction of dams used for generation of electricity. Before issuing a construction permit for such dams, the Board must consider their effects on scenic and recreational values, fish and wildlife, bathing, town revenues, forestry programs, and the natural flow of water below the dam. PSB must also consider applicable municipal and regionaj. plans. 130 Fnvironmental. and Energy Statutes

In 1971, a l.aw was enacted creating the Vermont Agency of Fnvironmental. Conservation, thereby combining functions previously performed by several state departments. This agency regulates those Land developments - including utility facilities - not covered under the Public Service Law. ${ }^{131}$

Severa]. water protection laws are used as criteria by PSB prior to granting permits for energy facility siting. Discharge of any waste into state waters is prohibited without a permit from the Department of Water Resources under the Water Pollution Control Act. ${ }^{132}$ Dredging, excavation and construction activities are controlled pursuant to the Regulation of Stream Flow Law. ${ }^{133}$ The purpose of this law, consistent with riparian rights, is to assure continuous flow of water in streams. The Protection of Navigable Waters and Shorelands statute was enacted to conserve the state's water resources by preventing pollution, controlling building sites, and preserving shore cover. ${ }^{134}$ The Lands Lyjing Under Public Waters Law applies to lakes and ponds in much the same way as the Stream Flow Law applies to streams. ${ }^{135}$ The Air Pollution Control Act also sets standards relevant to the state's energy facility siting process. 136

The Natural Gas and 0il Resources Act regulates these resources in the state. $13 \%$ It established the Gas and Dil Resources Board, which may enter into contracts for lease or sale of gas and oil resources on state-owned lands, 
including such resources under submerged lands.

State Land Use Controls

Vermont is one of the few states in the nation to have enacted a comprehensive state land use law, although many other states have such statutes in various stages of consideration. 138 However, Vermont's statute, the Land Ise and Development Act of 1970, does not apply to power plants or transmission facilities, which continue to be licensed under the state's Public Service Law. The detailed state land use plan required under the act was disapproved by the legislature in its mandated review, and is being redrawn.

\section{Conclusions}

Vermont's General Assembly has demonstrated a capacity to enact statutes still uncommon in the nation, including a legjslative override authority over proposed nuclear power plants, the state's comprehensive land use law (which does not, however, affect power plant siting) and a law banning non-refundable beverage containers. $^{*}$ These actions indicate the innovative quality of the state's 1awmakers, at least since 1.970 when the Land Use and Development Act became law.

The state's Public Service Law covers only power plant and transmission facility siting; other energy-related facilities are not covered by any such comprehensive state siting mechanism. This may be of less consequence in Vermont, which is the only non-coastal state of the six jin the New England region and thus does not have the same kind of energy development pressures related to Duter Continenta]. Shelf exploration and deepwater ports which confront states wi.th coastal shores.

* Vermont is one of only four states in the nation to have such a law. The others are Maine, Michigan and Oregon.139 
While the Vermont Public Service Law provides ancther example of a state mechanism reactive to the siting initiatives of private utilities, the Public Service Board does have broad criteria on which its decisions are to be based. These criteria include both impact on infrastructure and need for the facility, factors not present in a number of other state power plant siting laws. Vermont's legislation does not, however, adequately address the question of long-range energy facility planning as does, for example, neighboring New Hampshire's siting 1aw.

Siting Legislation in New England: Summary and Conclusions

Energy-related issues in New England involve a basic conflict between pressure to develop energy facilities in the region, and resistance to the shortand long-term environmental and economic effects of such development. In attempting to achieve a balance between environmenta.l quality and economic (or energy) development, the states of the region increasingly have devised new legjislative siting mechanisms, some of which remain untested. Although the institutional procedures vary from state to state, several common themes are evident. Each of the six legislatures in this region has vested in a state body the authority to override local decisions on siting of certain energy facilities, particularly power plants. All of these state agencies or commissions granted authority over energy facility siting serve in a coordinative capacity, in that they are to take into account the standards and permitting powers of other state agencies. This pattern differs from Maryland, for example, which has established an entirely new siting mechanism apart from the permit procedures of the other state agencies. Four have override power over the decisions of other state agencies; New Hampshire and Vermont are the exceptions 
to this pattern.

Provision for local decision by referendum over oil refinery siting proposals appears to be developing as a legislative trend in New England, having been enacted in Connecticut, Massachusetts, and New Hampshire. In Phode Island, the legislature (rather than the local government) must give its explicit approval to construction of any oil refinery. These moves are particularly significant in light of proposals by the federal government for Outer Continental. Shelf drilling for oil and gas in the Georges Bank off the New England coast. Five of the six states in the region (excepting only Vermont) have coastal areas, and this legislative sentiment is indicative of heightened concern over the effects of such activity. New Hampshire's action fol.lowed the controversial Durham proposal in 1973; the new refinery siting legislation was passed in Connecticut, Massachusetts and Rhode Island with the perspective of the New Hampshire case, as well as general concerns over the onshore impacts of ocS oil (and gas) activity. In addition, the succession of oil facility controversies in other New England states, especially Maine, have served to keep this a prominent issue in the region.

Another jnteresting New England trend was initiated in Rhode Island in 1974 and followed by Vermont in 1975, when by statute their legislatures reserved for themselves final approval or denial authority over all proposed nuclear power plant construction. (As mentioned, in Rhode Island this legislative authority also includes oil refineries.) Vermont's law was triggered by operational problems with the state's only nuclear power plant, Vermont Yankee.

The states of this region vary in the manner in which they meet several important siting criteria; in their coverage of al1 or only some energy facilities; 
in their attempts to balance environmental and economic impacts; in the scope provided for public participation; in the degree of 1ong-range planning; in their requirements. regarding proof of need for the facility; in the degree to which supply and demand factors are assessed; and in the extent to which the proposed facility would affect.infrastructure in the area. Maine appears to have the most comprehensive siting statute, although this law does not cover energy facilities exclusively. Maine's siting law, enacted in 1970, is also the oldest such measure in the region. and this state has had the most experience in coping with oil refinery siting proposals.

Institutional procedures in all six New England states remain reactive to the siting initiatives of utilities and energy companies; although Massachusetts and Rhode Island do have Port Authorities which can initiate energy proposals. Structural capability to formulate innovative state energy policy appears to have expanded significantly in Connecticut in 1.975 with creation of a Department of Planning and Energy Policy. Massachusetts in 1973 (and in subsequent amendments) devised a siting process wh1ch brought all types of major new energy facilities under the purview of a single state decision-making entity, the Energy Facilities Siting Counci.1.

Since the energy crisis of 1973-1974, the increased cost of oil has led directly to a rise in the cost of electric power. Public concern over energy costs has now become a major political issue in New England, which experiences Jonger and colder winters than other parts of the Northeast. This explains the spate of significant siting legislation after that time. The region remains very energy-dependent, with its industries, utilities and residences relying upon petroleum products for more than 80 percent of their total energy requirements. 
The degree to which the New England states value their large, unspoiled areas is evident in the number and variety of environmental protection statutes bearing on energy facility siting. The region now must plan for the onshore impacts of offshore oil and gas drilling; ${ }^{140}$ it must decide to what extent it will become dependent on nuclear energy; and it must decide on conservation measures which may alleviate some of these energy pressures. The six New England states cannot adequately plan for energy facility siting using only the reactive mode in which they now operate, but will have to guide their energy destinies with more positive actions. 
1. Peirce, Neil R., The New England States - People, Politics and Power in the Six New England States, (New York: W.W. Norton \& Co., 1976), pp. 31, 32; and Commonwealth of Massachusetts, An Economic Development Program for Massachusetts, August 1976, p. 12 .

2. Commonwealth of Massachusetts, Ibid., p. 14.

3. Peirce, op. cit., p. 31 .

4. Ibid., p. 34 .

5. Ibid.

6. Thid.

7. Ibid.

8. The Council of State Governments, State Headlines, No. 76-24, November 29, 1976.

9. New England Regional Commission (NERC), Annotated Index of Energy Facility Related Statutes, Energy Program Technical Report 75-4, Revised January 1976, p. i.

10. Peirce, op. cit., p. 33.

11. NERC, Annotated Index, op. cit., Preface,

12. PL 75-337.

13. New England Regional Commission, Decision-Making for Energy Facilities in New England: Institutional and Legal Process, Energy Program Technical Report 75-7, December 1975, pp, 156-157.

14. NERC, Annotated Index, op. cit., pp. Ct. 1, 1-z.

15. Interview by Grace Singer, Princeton University, Center for Environmental Studies Researcher, with Kevin R, Guernier, Research Specialist, Office. of Legislative Research, The Connecticut General Assemb1y, July 15, 1976.

16. NERC, Annotated Index, op. cit., pp. Ct. II, I-III, 3.

17. Ibid., p. Ct. IV, 1 .

18. Ib 1d., p. Cr. V, 4-5.

19. Ibid., p. Ct. V, 1 .

20. Ibid., p. Ct. V, 2 . 
21. The "Today" program, WNBC-TV, June 25, 1976.

22. Peirce, op. cit., p. 401, 402; also see Peter Bradford, Fragile Structures: A Story of Oil Refineries, National Security and the Coast of Maine (New York: Harpers, 1975).

23. Peirce, Ibid., pp. 403, 404.

24. "Proposed Oil Refinery in Maine Debated at Environmental Hearing," New York Times, December 5, 1976.

25. "Sears Island Power Plant is Abandoned", Trenton Times, January 26, 1977.

26. Peirce, op. cit., p. 402.

27. Ibid., p. 401 .

28. Ibid., p. 404 .

29. NERC, Annotated Index, op. cit., P. NE 6 .

30. Ibid.,.pp. Me. V. 1. - V.3.

31. NERC, Decision Making for Energy Facilities, op. cit., p. 119.

32. Communication to Singer from David H. Leake, Chief, Division of Information and Education, Maine Department of Environmental Protection, December 9, 1976 .

33. Ibid.

34. NERC, Decision-Making for Energy Facilities, op cit., p. 120-121.

35. Ibid., p. 121 .

36. NERC, Annotated Index, op. cit., pp. Me. I, 2-3; this law was amended in 1973.

37. Ibid., pp. Me. III, 3-4; this law was amended in 1973 and again in 1974.

38. "A Summary of State Land Use Controls", Land Use Planning Reports, July 1974 , p. 22 .

39. NERC, Annotated Index, op. cit., p. ME. III, 1; this law was adopted in 1967 .

40. Ibid., p. Me. II, 8; this law was adopted in 1974.

41. Ibid., p. Me. III, 2; this law was adopted in 1973. 
42. Ibid.» P. Me.III, 5; and "A Summary of Land Use Controls", ,op. cit.; this law was amended in 1973.

43. NERC, Annotated Index, Ibid., p. Me. III, 6.; this law was passed in 1974.

44. Ibid., p. Me. V, 6., this law was amended in 1973.

45. "A Summary of Land Use Controls", op. cit.; and Energy Facility Siting in Coastal Areas, report prepared for the U.S. Senate Commerce Committee and National Ocean Policy Study, December 1975, p. 41.

45. NERC, Annotated Index, op, cit., pp..Me. II, 4-6; this law was passed in 1970 .

47. Ibid., p. Me. II, 1; this 1 aw was passed in 1973.

40. Ibid., P. Me. IV, 1; this law was amended in 1969.

49. Ibid., Me. II, 6.

50. Northeast Legislative Energy Update, \#2, March, 19.76 .

51. Thid., p. Me. I, 1 .

52. Ibid., p. Me. V, 45 .

53. National Conference of State Legislatures, informal compilation of data on nuclear moratoria in the states.

54. Southern Interstate Nuclear Board, Power Plant Siting in the United States, September 1974, 1976 update; and NERC, Decision-Making for Energy Facilities, op. cit., p. 127.

55. H4921 (Chapter 26), adopted October 15, 1976.

56. Interview by Singer with Linda Sweeney, Legislative Aide to Joint Governmental Regulations Committee re House bills 4236 and 4268 of 1976, July 12, 1976.

57. Testimony by Roger D. Feldman, Deputy Assistant Administrator, Energy Resource Development, Federal Energy Administration, before the Subcomnittee on Energy and Power, Committee on Interstate and Foreign Commerce, U.S. House of Representatives on H.R. 12461, the "Electric Utility Rate Reform and Regulatory Improvement Act" (re. utility planning and siting), April 8, 1976.

53. NERC, Annotated Index, op. cit., p. Ma. I, 1.

59. H5271 (Chapter 468), adopted November 8, 1976.

60. H1970 (Chapter 559). 
61. Letter to Singer from Linda Sweeney, Legislative Aide, House of Representatives, Commonwealth of Massachusetts, December 2, 1976.

62. NERC, Annotated Index, op. cit., p. Ma. 21.

63. An Economic Development Program, op. cit., p. 14.

64. This law was passed in 1972 and amended in 1974.

65. This law was passed in 1966 and amended in 1974.

66. Ibid., p. Ma. II, 1-4.

67. Ibid., p. Ma. II, 5; this law was passed in 1929 and amended in 1971.

68. Tbid., p. Ma. II, 8; this law was passed in 1971.

69. Ibid., P. Ma. III, I; this law was passed in 1968 and amended in 1972.

70. Ibid., p. Ma. III, 5; this law was passed in 1965.

71. Ibid., p. Ma. III, 3; this law was passed in 1967 and amended in 1973.

72. Ibid., p. Ma. III, 3 and III, 6 .

73. Tbid., p. Ma. IV, 1-3; this 1 aw was passed in 1959 and has been amended several times since.

74. Ibid., p. Ma. 22 .

75. See J. Douglas Peters, "Durham, New Hampshire: A Victory for Home Rule?" Ecology Law Quarterly (Vol. 5, No. 1, 1975), pp. 53-67.

76. Peter M. Meier, Energy Facility Location: A Regional Viewpoint (Upton, NY: Brookhaven National Laboratory, Regional Energy Studies Program), August, 1975; Energy Facility Siting in Coastal Areas, op. cit., p. 7; "A Summary of Land Use Controls", op. cit., p. 35; and Interview by Singer with Barbara J. Goldsmith, Senior Environmental Planner, Environmental Research \& Technology, Inc., Concord, Mass., May 10, 1976.

77. NERC, Annotated Index, op. cit., p. NH. V, 2.

78. John Kifner, "Nuclear Plant in New Hampshire Loses Approval of Cooling Plan", New York Times, November 10, 1976, p. Al0.

79. "The Nuclear Cost of Regulatory Delay," Business Week, January 24, 1977, p. 22 .

80. Peirce, op. cit., p. 356 .

81. Ibid. 
32. NERC, Annotated Index, op. cit., p. NH. I, 1-3.

83. NERC, Decision-Making for Energy Facilities, op. cit., p. 145.

84. NERC, Annotated Index, op. cit., p. NH. I, 6.

85. Ibid., NH. I, 9; this law was passed in 1955 and amended in 1973.

36. Ibid., p. NH. 19 .

37. NERC, -Decision-Making for Energy Facilities, op. cit., p. 144.

33. Ibid., p. 108 .

89. Tbid., p. 109 .

90. Lbid., p. 111 .

91. Ibid., p. 112 .

9.2. This act was passed in 1967 .

93. NERC, Annotated Index, op. cit., NH III, 1; this law was passed in 1967.

94. Ibid., NH. IV, 1; this law was passed in 1967.

95. Ibid., NH. II, 3; this law was passed in 1971.

96. 42-64-14.1 of Rhode Island General Laws.

97. Business Week, February 23, 1976, p. 68F.

98. New York Times, May 10, 1976, p. 45.

99. Interview by Singer with Barbara J. Ashworth, Research Assistant, Rhode Island Legislative Council re 75-H6170, July 14, 1976.

100. Ibid.

101. NERC, Decision-Making for Energy Facilities, op. cit., p. 153, 154.

102. NERC, Annotated Index, op. cit., p. RI. I, 3.

103. Interviews by Singer with V.A. Nolan, Deputy Director for Finance and Administration, Rhode Island Department of Economic Development and with Jacques V. Hopkins, Attorney for the Department of Economic Development (law firm: Hinckley, Allen, Salisbury \& Yarsons), October $12,1976$.

104. Governor Phillip W. Noel's message to the Secretary of State vetoing bill 75H-5219A, which amended section 42-64-14.1 entitled "The Rhode Island Port Authority and Economic Development Corporation."

105. NERC, Annotated Index, op. cit., p. RI. V, 1-2. 
106. Ibid., p. RI. II, 1 .

107. Ibid., P. RI. II, 4; this law was passed in 1971.

108. Ibid., p. RI. II, 6; this law was passed in 1896 and amended most recently in 1970 .

109. The Coastal Wetlands 1 aw was passed in 1965, and the Inland Wetlands law in 1971.

110. Ibid., RI. III, 1 .

111. Council of State Governments, State Headlines, No. 76-5, March 8, 1976, p. 1 .

112. NERC, Annotated Index, op. cit., p. RI, IV, 1; this law was passed in 1966 .

113. Ibid.

114. Ibid., P. RI, 5 .

115. Interview with Ashworth, op. cit.

116. Proceedings of Meeting of Advisory Committee on Energy Facility Siting Held on October 24, 1976, Office of Energy R\&D Policy, National Science Foundation, February 1976, p. 92.

117. H. 127, Public Acts 1975, Approved April 3, 1975.

118. Interview by Singer with Joel Cherington and William Russell, Legislative Draftsmen, Vermont Legislative Council, July 14, 1976.

119. J.R.H. 67 .

120. Trenton Times, August 14, 1976.

121. Interview by Singer with Steven Eilperin, Counsel, Nuclear Regulatory Commission, February 7, 1977.

122. Interview by Singer with Richard Ayres, Attorney, Natural Resources Defense Council, Inc., Washington, DC, February 2, 1977.

123. Trenton Times, August 15, 1976, p. B-1.

124. Interview with Ayres, op. cit.

125. Trenton Times, op. cit., August 15, 1976.

126. New York Times, July 23, 1976, p. A22.

127. NERC, Annotated Index, op. cit., p. VT I, 7. 
128. K. Michael Irish, The Council of State Governments, Energy Information Newsletter - 75, Volume 6, p. 343.

129. NERC, Annotated Index, op. cit., P. VT.I, 1-2; and NERC, Decision-Making for Energy Facilities, op. cit., pp. 147, 148.

130. Annotated Index, Ibid., P. VT.I, 4.

131. E. Graf Webster et, al., Mitre Corporation, Resource and Land Investigations (RALI) Program, Volume III, Power Plant Siting, August 1974, p. 443.

132. NERC, Annotated Index, op. cit., p. VT., II, 1; this law was passed in 1972.

133. Ibid., p. VT. II, 4; this law was passed in 1965 and amended in 1969.

134. Ibid., p. VT. II, 6; this law was passed in 1969.

135. Ibid., P. VT. II, 3; this law was passed in 1969.

136. This law was passed in 1972 .

137. Ibid., p. V'l'. II, 6; this 1 aw was passed in 1961.

138. Interview by Singer with $\mathrm{Dr}$. Glenn Stevenson, Principal Scientist, The New York State Assemb1y, June 28, 1976.

139. Trenton Times, January 15, 1977.

140. See New England River Basins Commission, Factbook: Onshore Facilities Related to Offshore Oil and Gas Development, 1976. 
States -- and their legislatures -- have certain distinct characteristics which set them apart from one another. They vary in levels of activity, structural efficiency, innovation, leadership, responsiveness and research capability. This study has revealed some of these differences with respect to formulation of energy policy and legislation in the eleven states of the Northeast. At the same time, certain common themes have been identified which form patterns and perceptible trends across these states.

\section{Overall Energy Policy}

Each state's stance on energy policy may be characterized in brief as

\section{follows :}

New Jersey - This state was. bogged down for over two years with a tax and budgetary crisis. Caught in the quagmire of political fractiousness and lack of leadership, no clear mandate to devise energy policy has emerged. As a result, numerous energy proposals have been languishing in legislative committees since 1974 .

Maryland - A highly. innovative power plant siting law (unique in the U.S.) was enacted in 1971, with provision for extensive basic research and for state site acquisition financed from a surcharge on electricity generation. The state has moved much more slowly on other energy issues; including energy conservation.

New York - This state has a comprehensive and progressive facility siting law for power plants, transmission lines and gas pipelines, and a state Power Authority. However, it has been stalled on other energy issues due to lack of state -- and federal -- policy and standards to provide the impetus and act as a framework for legislation. In addition, legislators have been preoccupied with financial crises in New York City and the state as a whole. No comprehensive state review. mechanisms exist regarding facilities related to oil or gas.

Pennsylvania - This state is encumbered by an unwieldly legislative structure and procedural rules, particularly in its House of Representatives. The resultant policy vacuum on energy policy, facility siting, land use and other related energy issues has left the state in a vulnerable position. 
This is especially important in light of a proposal to develop a large energy center in the state, and because Pennsylvania is the only state in the Northeast with abundant fuel resources -- coal -- and potential for extraction of gas from Lake Erie.

Delaware - Energy policy has remained a low-profile issue in this state. The 1971 Coastal Zone Act barring heavy industry, including energy facilities, from locating in that area was enacted primarily in response to proposals for a refinery and deepwater port. This law may be superseded by statewide land use legislation, with results for energy facility siting at present remaining uncertain.

Connecticut - This state's comprehensive energy facility siting laws, including several enacted in 1975, establish an energy planning mechanism coordinated with 1 and use and other resource planning functions; a Nuclear Power Evaluation Council; and a local referendum process prior to approval of oil refineries. Development of a new energy resource management plan could result in state initiatives in facility siting, rather than the current reactive position common to most of these Northeast states.

Maine - This state has an extensive array of environmental laws affecting energy facility siting and a comprehensive "one stop" siting law for all major industrial facilities, including energy facilities. This was the first such law in the Northeast when it was enacted in 1970, and was prompted, in part, by pressures for development of oil facilities.

Massachusetts - This state's comprehensive energy facility siting law is combined with local veto over decisions involving oil facilities. No mineral leasing is allowed in state waters until the state has obtained information as to quantity, quality, location and possible risk to marine and other resources. This 1 aw is in sharp contrast to federal procedures granting leases on the Atlantic Ocean OCS to oil companies prior to ascertaining facts about the quantity of resources and environmental impacts of their development.

New Hampshire - This state's comprehensive energy facility siting law again is combined with procedures for local approval (or veto) of proposed oil refineries. This endorsement of decentralized decision-making was passed in response to the 1973 controversy in Durham, N.H., whose citizens voted against locating a large oil refinery in their town. The state legislature refused to overturn this local veto, although urged by the Governor to do so.

Rhode Island - This state has no comprehensive siting $1 \mathrm{aw}$, but the legislature has assumed explicit override authority on location and construction of oil refineries and nuclear power plants.

Vermont - The only non-coastal state of the eleven included in this study, this state's legislature has enacted only very limited energy facility siting legislation. However, the legislature has assumed explicit override authority over nuclear power plant construction, responding to general nuclear concerns of the state's citizens and to specific problems with the state's only nuclear power plant. 
Conflicting Energy Policies

Several examples indicate how states, even in the same region, may have sharply opposing views on certain energy issues. Policy toward Lake Erie provides one illustrative case. At the same time that New York has been giving serious consideration to approval of exploration for natural gas in the lake (currently Canada has 300 active gas wells there), Pennsylvania's legislature has been taking action to prohibit such activity in this same lake because of its concern over the possibility of oil spills.

Another example of interesting opposites comes from New Jersey and Pennsylvania, both of which have had proposals for large energy centers (a hypothetical study in New Jersey, an actual proposal by utility companies in Pennsylvania). New Jersey -- and some other states -- currently allow all tax benefits from large energy facilities, including power plants, to accrue almost entirely to localities. ${ }^{1}$ Because some localities receive immense tax benefits while their nelghbors receive none, suggestions have been made in the legislature to alter this process to permit more even distribution of benefits, making the state a partial beneficiary of these tax revenues. The broad regional impact of large energy facilities, like an energy center, lend weight to this argument. In contrast, in Pennsylvania the prime beneficiary of utility taxes is the state, and suggestions have been put forth to change this situation so that localities could benefit more directly. Proponents of such a change feel that this might help to overcome local resistance to siting of energy facilities like the proposed cluster of power plants. Thus these two states, starting from opposite extremes, are both seeking the proper allocation to their citizens of the costs and benefits of major energy facilities, searching for equity as the basis of political compromise. In neither case, 
however, is new legislation close to passage in these two state legislatures.

Response to Crisis: A Characteristic of State Legislatures

Energy issues tend to be characterized by a crisis-response mode of public policy formulation. Ignored for months or years because of their technical complexity and diffuse constituency, specific issues emerge suddenly in the forefront of public concern, forcing the elected Senators and Assembly members to take some kind of action.

This characteristic explains a number of the obvious differences among the Northeastern states in terms of their particular focus within the broad spectrum of energy policy concerns. Maryland's legislature responded to the controversy over the Calvert Cliffs nuclear power plant on Chesapeake Bay by enacting an impressive power plant siting act, shifting much of the initiative for site identification and acquisition from the utility companies to the state's Department of Natural Resources. In Delaware, proposals for a deepwater port and a large new oil refinery combined with desires to protect the state's ecologically-fragile coastal area, thereby providing the political basis for enactment of the state's stringent Coastal Zone Act. Similarly, controversy over the proper forum for decision-making on oil refinery siting engendered by the Durham, New Hampshire and Machiasport, Maine proposals prompted a number of New England states to pass legislation endorsing complete local veto over such facilities. Power plant siting in New England, to date, has not provoked such strong local animosity, and state override authority continues to exist for such facilities. In Pennsylvania, however, proposals for an "energy park" stimulated so much local concern. that revision of utility taxation statutes is being viewed as one way to obtain easier local approval, through providing more tax revenues to 
the locality rather than to the state. Moreover, this legislature formed a special joint commission to examine the energy park proposal, one of this body's few responses in the energy arena.

If this crisis-response mode of energy policy formulation holds into the future, as seems likely, one might predict passage of stronger statewide energy facility siting legislation in New York, New Jersey, and several New England states, in order to cope more effectively with the onshore impacts of offshore oil and gas activities. Pennsylvania (and New Jersey or New York) might be expected to enact legislation setting forth comprehensive state review mechanisms for review and approval of energy clusters. Moreover, the public debate over nuclear energy seems certain to stimulate passage of new controls over nuclear development in several of these states, either on the pattern of required legislative review seen already in Rhode Island and Vermont, or through granting local veto power over nuclear power plant siting akin to that now in effect for oil refineries in several of these eleven states.

\section{Comprehensiveness of State Energy Legislation}

These Northeast states also vary widely in the degree to which their legislatures have enacted comprehensive energy legislation. Maryland, New York and Connecticut have incorporated long-range planning into their decisionmaking processes, especially for power plant siting. Typically, each utility is required to submit to the state (and make public) a ten-year facility development plan, based on the company's projections for electricity demand. Such plans may include designation of primary and alternate sites for power plants, transmission corridors, and -- in Connecticut at least -- similar information for oil and gas pipelines in the state. These plans normally are 
updated on an annual basis.

Massachusetts' new law combines energy planning and siting decisions in the same executive branch agency. New York, however, has separate processes for state review of gas pipelines and electricity transmission corridors on the one hand, power plants on the other. Another contrasting structural model is seen in Maine, where one agency -- the Board of Environmental Protection -- has responsibility for siting decisions, while others -- the office of Energy Resources and the Energy Resources Advisory Council -- are charged with energy planning and development of a statewide energy policy. S̄tates like New Jersey and Pennsylvania still have almost no state energy planning stipulated in their legislation, continuing to rely almost entirely on the utility and energy companies to perform this function. State decision-makers then react as best they can to the companies' specific proposals.

Executive - Legislative Relations in the Energy Arena

These notable differences from one state to another within the Northeast region reflect not only the intrinsic differences in these states' particular energy situations, but also are indicative of the nature of overall relations between the state legislature and the executive branch of government: the Governor, his personal staff, and the several agencies concerned with energy. In several states, the principal initiative for new energy legislation has emanated from individual members of the legislature, who studied the issue and devised legislation which eventually was enacted into law. Maryland's Power Plant Siting Act provides an example of this pattern. In other states, the Governor's office has initiated new legislation, often bills initially written within executive branch agencies. This was true of New York's energy 
reorganization to create the state ERDA, for example. Frequently, of course, an interactive process is underway, with alternative legislative proposals from legislators and the Governor forming the basis of a compromise which eventually emerges as the statute passed into law. New Jersey's Coastal Area Facility Review Act (CAFRA) provides a classic example of this complicated pattern of executive-legislative relationships. ${ }^{2}$

Often energy specialists in the executive branch of state government perceive as obstructionists both members of the state legislature as individuals, and the legislature as an institution. Senators and Assembly members, by definition, are generalists, representing a wide range of concerns from their electoral constituency. Dealing with the technological complexities of energy policy can be frustrating to them, and -- unless strong leadership emerges either from the Governor or from individual legislators -- their preference is to defer the tough decisions. This pattern fits with the crisis-response mode noted earlier, for crises generate sufficient political attention so that deferral is impossible. Some kind of action becomes imperative. Otherwise, legislative committees will hold hearings to "discuss the issues," and will happily form new study groups and commission, but the tough decisions will be avoided whenever possible.

Many members of the executive branch of state government become frustrated at the glacial pace of action in state legislatures on issues like energy policy. They blame legislators for dilatory maneuvers, for failing to make the tough decisions these people believe are needed. However, enough examples of legislative initiative do emerge from this study to suggest that it is simplistic to place the blame totally on the legislature. Where is the leadership from the Governor, the only individual in the state to speak from 
a statewide electoral constituency? Energy issues of ten require action at state, regional, or national leve1, and are not well suited to the focus of an individual Assembly or Senate district. Energy specialists often have been unable to induce the various Governors to act forcefully on energy matters, to exert statewide leadership in the search for new patterns of energy demand and supply. When faced with tough issues like energy, Governors, like legislators, tend to prefer inaction and deferral to forceful leadership. They too must choose whether to follow or lead their constituents, a choice dictated by the political dynamics within the state more than by Lhe intrinsic merita of alternative responses to the energy challenge.

In any discussion of energy, the crux of the matter lies in the three important E's: Energy, Environment and Economics. ${ }^{3}$ That triangular depiction suggests the underlying tension and dilemma wh1ch make entrgy policy onc of the most thorny and urgent issues of our time. Four specific categories have emerged as major policy problem areas with which the states of the Northeast are attempting to deal:

(1) Decisions on energy facility siting

(2) Formulation of federal and state policy and standards

(3) Establishment of and roles for state energy offices

(4) Structure and staffing in state legislatures for energy policy.

Each of these policy areas is addressed in turn.

\section{Decisions on Energy Facility Siting}

A trend toward "one-stop" siting procedures has emerged in the states of the Northeast, primarily in response to demands to streamline state review of energy construction proposals and obviate the need for multiple permit applications to numerous agencies of state and local government. Most of these revised procedures include site certification, review by an interdisciplinary 
regulatory board, environmental impact assessment to allow consideration of enviornmental factors in the review process, state override of local authority to veto proposed sites, and public hearings of some kind. Some of these Northeast states require long-range forecasting of energy needs, advance selection of possible sites, and explicit consideration of alternate sites in each siting decision.

Six of the eleven Northeastern state legislatures (four of these in New England) have passed laws for comprehensive, interdisciplinary siting procedures which assess economic, energy and environmental factors. Such assessments are conducted to a lesser or greater extent in each of these states. In those states without such comprehensive energy facility siting laws, the state Public Service Commission or local governments remain the principal decision-making bodies. However, even the more comprehensive laws do not always mandate assessment of long-range energy needs nor take into account vigorous conservation efforts, maximum use of alternate sources of energy, or effects of the facility on infrastructure in the area.

The most pervasive and fundamental fact to emerge about the states' siting laws is that they are essentially reactive to the initiatives and prior decisions of the private utility companies. This is as true for basic energy assumptions (growth rates, etc.) as for selection of specific sites. The notable exceptions are Maryland, which has its own extensive state research and site acquisition program (albeit based primarily on sites initially proposed by the utilities) and, to a lesser extent, New York, where the State Power

* In 1972, only five states in the entire nation had comprehensive power plant siting laws. By September 1974 this number had increased to 18, and to 24 by April 1976.4 
Authority acquires sites and constructs and operates energy facilities

primarily for municipal and rural electric systems. (The Maryland law provides for use of surcharge payments to support research and site acquisition, with payments based directly on the amount of energy used. Thus, those using more energy pay accordingly.)

Because of the major impacts of energy facilities, siting statutes on this topic frequently are the first and foremost example of state exercise of land use authority subsequent to its delegation to local governments. Yet, even when states have eutigy facility siting laws, the lack of an overall state land use law leaves them without the broad institutional authority and mechanisms with which to choose sites for energy facilities from the viewpoint of most desirable and efficient land use, and the least environmental and infrastructure impacts. Of the 11 Northeastern states, only Vermunt has such a law, which appears to include no specific energy features. Maine has a set of laws which, in the aggregate, constitute rather broad authority. Several other states have land use proposals under study; some have been rejected by their legislatures. Recognition is now given to the secondary impacts resulting from construction of sewage systems and highways, and energy facilitice too must be seen in this context. Aralysis of Northenatnrn state laws and interviews conducted during this research effort do not indicate that such recognition is yet a prominent consideration in most of these states.

Striking distinctions are apparent in the different approaches most states have taken toward control over power plant siting as a special case, as opposed to decisions on locat1uns for other ltew energy facilities: oil refineries, storage tanks, natural gas separation plants, pumping stations, or storage farilities; or to support facilities for offshore energy activities. 
Under traditional procedures which have emerged over the past half-century, all eleven states have laws allowing use of eminent domain to obtain sites for new power plants. Normally, exercise of this eminent domain authority by utility companies is controlled by the state's Public Utilities Commission, Public Service Commission or similar agency. In many of these states, this type of state override power exists.for electricity transmission lines as well, and in Connecticut for gas pipelines, too. However, New Jersey illustrates the complexity of this situation. In that state electric utility companies can use eminent domain where necessary to obtain land needed for transmission lines, but not for power generating stations. In no state in the Northeast, however, are natural gas separation plants, ${ }^{*}$ oil refineries, or similar energy facilities covered under provisions for state override and use of eminent domain. Nuclear power plants and oil refineries have received special attention in state legislatures in the Northeast, particularly in New England. Most of the eleven state legislatures in the Northeast have considered proposals.of some kind to exercise greater control over nuclear power plants, although many of these bills or resolutions remained in legislative committees as of late 1976. The legislatures of Vermont and Rhode Island have reserved to themselves explicit override authority over construction of nuclear plants. ** These concerns about nuclear energy illustrate several basic questions facing most states: To what extent will they become dependent on nuclear energy? To what degree is this dependence acceptable to residents in these areas? Do any viable alternatives exist? Can a state control its own destiny in this regard?

\footnotetext{
*Federal override authority might be exercised for natural gas facilities.

** Federal pre-emption might well render such state statutes void under present federal legislation (the Atomic Energy Act of 1954, as amended).
} 
Al though the six New England states have general override authority over decisions of local governments on energy facilities, there is a trend throughout that area to permit local voter referenda to approve or disapprove proposed oil refinery sites. This wariness is attributable to past controversial refinery siting sisues, particularly in New Hampshire and Maine, and to the onshore impacts of Outer Continental Shelf oil and gas drilling. ${ }^{6}$ However, Massachusetts held a non-binding statewide voter referendum in November 1976 on permitting or prohibiting oil refinery and deepwater port facilities in the state. These facilities received an affirmative vote, but local veto power is still permitted. In Rhode Island, the legislature has assumed final approval authority over nil refinery siting and construction.

Distinctions and differences are also apparent in the degree of comprehensiveness or coveraye of new eiting statutes, their particular approach to the siting problem. A few of these states have brought all major new energy facilities under state control, either by themselves as in Massachusetts or along with other major new non-energy developments as in Maine. A comprehensive approach to power plant siting is seen in New Hampshire, Vermont, and (with particular innovation lu advance site acquisition by the state) in Maryland. In New York and Connecticut the state siting law encompasses pipelines as well as power plants, although New York separates its review of power plants from that for electricity transmission and gas pipel1nes. Delaware and New Jersey have enacted state controls over energy facility siting in their coastal areas, but lack comprehensive planning or review authority elsewhere. Finally, in Pennsylvania, nu speclal blate npprovals for power plants are required if local zoning approvals have been obtained.

A fow of these states have passed legislation designed to integrate long- 
term facility planning -- itself based on analysis of state's future energy requirements -- with specific siting decisions. Maryland provides the best example of this phenomenon, at least for power plants. Connecticut and New York require utilities to submit, and periodically revise, long-term siting plans; and the 1975 Massachusetts energy reorganization includes an integration of long-range planning and specific responsive siting decisions in the same agency. The other states, however, have done little if anything in this regard. The alphabetic lexicon of new state energy facility siting agencies has produced some acronyms which seem more cumbersome than colorful:

-- BEP, Maine's Board of Environmental Protection

-- BPSEC, New Hampshire's Bulk Power Site Evaluation Committee

-- CEC, New Jersey's Cabinet Energy Committee

-- CZICB, the Coastal Zone Industrial Control Board which administers Delaware's Coastal Zone Act

-- EFEC, another New Hampshire agency, the Energy Facility Evaluation Committee

-- EFSC, the Massachusetts Energy Facility Siting Council

-- PFEC, Connecticut's Power Facilities Evaluation Council.

The various states have also adopted differing approaches to constituting these energy decision-making entities. New Hampshire's BPSEC and New Jersey's CEC, for example, are comprised entirely of the heads of relevant state agencies. In contrast, all ten members of Maine's BEP come from the general public, appointed by the Governor from defined interest groups in the state. The state's Commissioner of Environmental Protection is ex officio Chairman of the BEP, voting only in the event of a tie amongst its members. Massachusetts' EFSC and Connecticut's PFEC contain a mixture of state government officials and members of the public. This degree of variation is suggestive of the 
complexity of energy issues to which each state is responding, and their political implications for that particular state.

Some of these state agencies truly offer "one-stop" approval, as they have the authority to overiide the views of other state units. This is true. of Maine's BEP, Connecticut's PFEC, and New York's Public Service Commission, at least for power plant siting. However, the central energy agencies in New Hampshire (BPSEC), Rhode Island (PUC) and Vermont (PSB) cannot exercise positive authority over the negative decisions of other state agencies, all of which maintain veco puwer in thcir areas of appropriate jurisdiction.

\section{Formulation of Federal and State Policy and Standards}

The lack of clearly-defined overall energy policies or standards on both federal and state levels has remained a serious constraint to formulating effective state energy planning programs, including activist conservation efforts and full use of alternate sources of energy supply. Such policies, if they existed, could serve as a framework in which state legislatures could begin to take effective, coordinated action.

One example of this constraint in operation comes from New York, where many bills have been introduced offering incentives for uge of solar power. However, since there are as yet neither federal nor state standards nor consumer protection rules for use of solar equipment, legislation has been stalled because legislators have been hesitant to act. In addition, some. interesting legal questions remain unanswered, e.g., what happens if a building with solar panels has a taller building constructed close by, blocking nut the sun? Another example of delay in policy formulation in New York occurred with proposals for improved energy efficiency in electric appliances. Under the 
federal Energy Policy and Conservation Act of 1975, the National Bureau of Standards must establish guidelines before a state can move forward on such conservation legislation; since these guidelines have not yet been provided, action on the state level cannot proceed.

More importantly, many state legislatures have been consumed with other pressing issues, so that energy policy formulation has not become a priority item -- except for a brief period in late 1973 and early 1974, in the immediate aftermath of the Arab oil embargo. The fiscal crisis in New York, the income tax tangle in New Jersey, and the concern over unemployment throughout all of these Northeastern states illustrates the degree to which energy policy has been forced into a subordinate position by the press of other events.

\section{Establishment of and Roles for State Energy Offices}

Another constraint on effective state action has been the absence in most Northeastern states of State Energy offices. with broad mandates related to long-range planning, conservation, research and development of alternate sources, supply and demand, and so on. Of the eleven states of the Northeast, Connecticut's Department of Planning and Energy Policy appears to be the most substantial. It was established in July 1975, with a staff of 46 . New York's Energy Research and Development Authority (NYSERDA) appears to have the most comprehensive state scientific research program regarding alternate sources of energy. The other nine states have vested varying degrees of authority in their State Energy offices. Some SEO's have at most only token operations, centering on emergency fuel allocation, a residue of the crisis days of 1973-74. Without an adequate SEO mechanism, the states are seriously handicapped 
in developing effective energy plans and policies, coordinating them as required with their constituent local governments, with each other, and with the numerous federal agencies responsible for various aspects of energy policy. As a result, states have become overly dependent on federal decisions and on decisions of the energy industry, unable to determine their own energy destiny as responsible partners in a federal system of governance.

\section{Structure and Staffing for Energy Policy in State Legislatures}

Again, the states of the Northeast vary widely in their legislative structures related to energy policy, and in their levels of staff capability. New York's substantial eneıgy slaff at the legislature rontrasts, for example, with Delaware's non-existent legislative staff for energy policy. In some cases, lack of adequate staff appears to be a serious handicap, but in many cases it has not posed any major constraints because state legisiatures have not seen energy policy as a priority issue. This has been due in part to other pressing matters usually involving finances, as in New York, New Jersey, and Delaware, and due to lack of leadership in this complex area of technology and publ1c policy.

It is highly doubtful that the mere presence of legislative staff for energy policy -- which, for example, New York has -- constitutes a decisive factor. It certainly has not in New York. First, states must establish energy policy as a priority issue. Once this basic deciston has beti reached, obtaining staff will naturally follow, although smaller states may be somewhat hampered in obtaining staff with high levels of expertise. Such states should be able to call upon some qualified regional resources. The Maryland legislature, for example, instead of maintaining its own research staff, purchases the. 
services of an outside research organization. This may be an alternative model worthy of serious consideration by other state legislatures.

Legislative structure in some states also may require alteration if the state government is to be able to cope successfully with the complex subject of energy. This is particularly true in Pennsylvania with its immensely cumbersome procedures, and in New Jersey whose committees do not meet as often as, for example, Maryland's committees, affording less continuity to deliberations in New Jersey's legislature.

Most Northeastern states currently are under pressure to alleviate the burden of high energy costs from residential and industrial consumers, and many of their energy proposals relate to rate structure and utility commission functions. Attempts are being made to begin modest conservation programs (car pooling for state employees, right-turn-on-red-1ight provisions, and so on) which will qualify states for federal financial assistance under the Energy Policy and Conservation Act. However, these piecemeal programmatic approaches lack a comprehensive framework to achieve a maximum effect. In any event, these actions do indicate a trend of forward motion, although at a seemingly slow pace in relation to the enormity of the task which still lies ahead.

\section{$\underline{\text { Recommendations }}$}

Over three years have passed since the latent energy crisis attained political explicitness, placing the states on notice that energy issues could no longer be ignored. The exigencies of providing adequate energy supplies to maintain a vital economy, while minimizing adverse environmental, land use and public health impacts, require sustained and sometimes innovative efforts, particularly in the four areas of energy policy described above. To date, 
at least, the states of the Northeast have not performed very well in meeting this new public policy challenge.

\section{Recommendations Regarding Energy Facility Siting}

The Tenth Amendment to the U.S. Constitution reserves for the states those powers not specifically conferred on the federal government. Traditionally, this amendment has been interpreted as vesting in state (and local) governments the authority to regulate 1 and use, among other powers. 7 Currently the states bear major respulsilility for reaching energy facility siting decisions. In order to make these decisions more effectively, however, these states will have to initiate land use planning processes which could then serve as the framework for selecting the most desirable sites within the state at which to locate various necessary energy facilities.

Beyond site selection, it is essential that the states shed their reactive stance relative to the basic energy assumptions upon which these energy fac1lities are launched: growth rates, conservation, alternate sources, supply and demand, social effects on: infrastructure, impact on cunmunity quality of 1.ife, and so on. Alteration in basic posturc should be accomplished with sufficient pubiic and local goveliment purtieipetinn to assure maximum inputs from different perspectives, thereby gaining acceptance of ultimate decisions on specific sites needed for energy facilities. As energy 1ssues gain greater political salience, stronger legitimacy through popular support will become ever more crurial. 8 At the very least, as an interim measure, those states which still have virtually no siting laws us -- at hect -- rudimentary siting mechanisms, should move to implement comprehensive state review programs which include consideration of the basic assumptions referred to above. 
Maryland's siting bill might be considered a model, with possible applicability to other states of the region and to other facilities beyond power plants.

\section{Recommendations Regarding Federal and State Policy and Standards}

Effective energy policy is composed of many large and small measures. Without a framework of clearly defined overall policies, however, it is difficult to understand the value of and then implement necessary measures pertaining to conservation and a1ternate sources, for example.

Federal action should serve as the umbrella under which states are offered adequate incentives for conservation and alternate source enhancement, e.g., use of cogeneration of electricity and process steam in industry. ${ }^{9}$ The states must begin to pursue such programs actively, but without federal guidelines and sufficient incentives this is very difficult. Examples of this pursuit are seen in the 1975 New Jersey State Uniform Construction Code Act, which includes an energy subcode fostering energy conservation, and in the City of St. Louis which is operating plants to recycle solid waste into steam used for heating public buildings. Such measures will have to become the rule rather than the exception if adequate energy, economic viability and a sound environment are to be assured.

Effective local energy planning has been hampered by a lack of both funds and information. Only a small percentage of municipalities are aware of the broad range of activities which can be conducted at the local level. Two federal 1aws, the Energy Polfcy and Conservation Act of 1975 and the Energy Conservation and Production Act of 1976, create programs to fund state and local energy planning. Although some data are available on conșervation, a serious shortage of information exists on the possibilities of local 
alternative energy development. ${ }^{10}$ Broad dissemination and understanding of such data are essential in order to encourage local participation in vital energy programs.

Since ten of the eleven states of the Northeast have coastal locations, another federal law -- the Coastal Zone Management Act of 1972 -- holds great potential in guiding land use planning in these critical areas. CzMA makes funds available to the states, which are required to develop by June 30, 1977 a mechanism for the protection, enhancement and development of their coastal resources. This federal-state partnersh1p piogram will strongly affect energy facility siting and should be integrated with progressive planning including energy conservation and alternate energy sources.

\section{Recommendations Regarding State Energy offlies}

To achieve energy management programs, it is essential, that a single state agency be given broad authority, adequate staff, and financial resources to research, plan, implement and coordinate energy programs with federal, state and local governments, industry, consumers, and the public at large. For example, transportation strategies to foster energy conservatlun can be implemented by a State Energy Office working with the State Department of Transportation and with local governments and regional transportation planning agencies.

California's Energy Resources Conservation and Development Commission has been rêferred to as a pussiblc model for nther states in this regard. It is uniquely funded by a tax of $0.1 \mathrm{mil}$ per kilowatt-hour of electriclty sold in the state: 'The Commission's' functions include site certification, conservation programs, forecasting and assessment, research and development of alternate 
energy sources, setting standards for housing and appliances, developing emergency allocation plans, and enforcement. None of the Northeastern states studied for this report have a single state energy management agency with this. kind of broad mandate, although Connecticut's agency probably comes the closest.

\section{Recommendations Regarding Legislative Structure and Staffing}

Once state legislatures begin to focus on energy as a priority issue, it is essential that adequate staff assistance be provided for research and coordination. Busy legislators who must deal with many complex issues aside from energy, very often on a part-time basis, need trained, competent aides if they are to formulate effective state energy policies. If smaller states cannot afford such legislative staff expertise, a regional institutional mechanism such as the Northeastern Legislative Energy Staff or the New England Regional Commission should be in a position to service such state legislatures, financed by a special fund to which each participating state contributes.

In order to garner maximum benefit from such expertise and be able to convert it into effective energy policy, some legislatures may require adjustments in their structure and procedures. For example, more frequent committee meetings may be needed to foster continuity of deliberations. A number of other streamlining measures would appear to be in order, particularly in Pennsylvania, although these may indeed prove very difficult to accomplish.

\section{Regional Coherence and Effective Leadership}

These state legislatures should also give greater consideration to regional approaches to energy problems, particularly siting. This will require coordination and data exchange channeled through organizations which can begin to foster integrated regional energy planning.

With the advent of ocs energy activities directly affecting many Northeast 
states, regional responses will become particularly important. Meeting the oCS challenge and coping with other far-reaching energy issues will require sustained positive actions by the states to avoid making policy decisions solely on a crisis-to-crisis basis, in response to initiatives taken by the energy industry, the federal government or even by local governments. The Northeast region and its component eleven states must plan for the onshore impacts of offshore oil and gas activities; they must determine their degree of future dependence on nuclear energy; they must achieve an acceptable balance between energy development and environmental protection; and they must der.ide on how best to implement selective, energy conservation measures to alleviate some of the pressures for expanded facility siting. These actions will require a far greater degree of regional coherence than has been demonstrated to date. Only very recently -- in November 1976 -- have the governors of some Northeastern states joined in addressing energy and other economic problems on a regional basis. These fledgling efforts, to be taken in concert with federal financial backing, appear to be the most hopeful occurrence thus far in energy planning in the Northeast and deserve vigorous pursuit.

Prior to this mnve, the entrgy issuc in most of these eleven Nurtheastern states had not been recognized as an integral and legitimate part of state government, at least when energy is defined conceptually in terms of overal1 resource management of a critical commodity. To these states, energy has remained primarily a financial transaclion related to eupplies nf electric power, thus involving the histurical regulatory rate-setting functions of each state's Public Utilities Commission. Only recently have state leglslalures (ās wcl1. as Governors and executive branch agencies) been forced to assess their extant inadequacies to cope effectively with the full magnitude of this policy 
challenge. These reassessments, documented in this study, have emerged primarily because of the inescapable political pressures of the land use focus of energy facility siting, the increasingly excessive reliance on automobiles throughout our sprawling metropolitan areas, the high (and growing) cost of energy in all itṣ forms, and the worrisome scenarios of shrinking energy supplies vulnerable to sudden disruption. Each of these states, however, has had to accomplish its reassessment in the absence of a clear regional or national energy policy, rendering parochial interests dominant within each state's jurisdictional horizons.

Energy decisions often are difficult to make, and easy to defer. American society has become accustomed to patterns of ever-increasing supplies of energy, accompanied by low prices. As a result, any alterations in this obviously desirable (if now impossible) situation have been met with passive and even active resistance, constraining the states' abilities to implement innovative efforts toward energy conservation and energy efficiency. The evident discomfort in both legislative and executive branches of government resulting from this fact has served to stagnate policy formulation on both national and state levels. Each participant keeps waiting for some other actor to assume policy leadership.

To date, few recognized individuals have been able successfully to advocate an encompassing policy or strategy that reflects the varied needs and aspirations of a given state or region, either on its own or in tandem with the natlonal interest (however that interest might be defined). Rather, the multiplicity of agencies involved in the energy tangle on all levels have competed with each other for attention, budgets, and regulatory authority. In the process, all have lost sight of the over-riding need for coherent policies and 
strategies. Clear policy initiatives have been stifled by the many competing actors: FEA, ERDA, EPA, Commerce, NRC, FPC, Interior, the national 1aboratories, OMB, the Congress at the federal level, plus similar patterns of jurisdictional overlap within each of the states. Given all this, it is perhaps surprising that several of the Northeastern states have accomplished as much as they have in coping with the energy challenge.

Obviously, some kind of new organizational framework for energy is required, and in many states the legislature will have the greatest responsibility for impelling its formation. Effective energy policy must be based on a coalescence of many diverse programs, each individually not very significant but which, in the aggregate, form a mosaic adequate for success. For example, each of the various energy conservation measures or alternate sources of energy, taken alone, w1ll alwunt to very little. Taken together, however, this combination of many specific policies and programs will begin to make a great difference in each state's requirements for energy. Moreover, public support is crucial, for without it energy strategies -- no matter how sophisticated -simply will never be implemented. State legislatures are uniquely capable of devising the political compromises necessary for such a llusaic to develop and of garnering needed public support; they wlll alsu need to devilie statutra for organizational coherence within the executive branch, providing the basis for implementation of such a multi-faceted strategy.

Herein 1ies the opportunity for effective energy policy, through development of such a coordinated mix of action programs and strategies. Yet here, too, lies the difficulty and the challenge, for organtzilion, leadrahip, and establishment of priorities and goals are all necessary prerequisites. State legislatures, in sum, can become paramount institutions in determining who shall be the master of their state's energy destiny. Whether they will do so, however, remains to be seen. 
1. See Peter Meier and David Morell, Issues in Clustered Nuclear Siting (Upton, N.Y.: Brookhaven National Laboratory, BNL 50561, October 1976), pp. 255-275.

2. See Malcolm D. Rivkin and David Kinsey, "New Jersey: Formulating an Interim Land Use Policy," Environmental Comment, November 1976, pp. 11-14.

3. See Gerald Garvey, Energy, Ecology, Economy (New York: Norton, 1972).

4. Southern Interstate Nuclear Board (SINB), Power Plants in the United States, September 1974, p. vii, and Testimony by Roger D. Feldman, Deputy Assistant Administrator, Energy Resource Development, Federal Energy Administration, before the Subcommittee on Energy and Power, Committee on Interstate and Foreign Commerce, I.S. House of Representatives on H.R. 12461, the "'Electric Utility Rate Reform and Regulatory Improvement Act" (re. utility planning and siting), April 8, 1976.

5. See Council on Environmental Quality, The Growth Shapers: The Land Use Impacts of Infrastructure Investments (Washington, DC: US Government Printing Office, May 1976).

6. See US Congress, Office of Technology Assessment, Coastal Effects of Offshore Energy Systems (Washington, DC: OTA, November 1976).

7. Energy Facility Siting in Coastal Areas, Report prepared for use by the Committee on Commerce, U.S. Senate (Washington, DC: US Government Printing Office, December 1975), p. 1 .

8. See Amory B. Lovins, "Energy Strategy: The Road Not Taken," Foreign Affairs, October 1976, Vol. 55, No. 1, pp. 65-96.

9. See Robert Williams, The Potential for Electricity Generation as a Byproduct of Industrial Steam Production in New Jersey (Princeton, NJ: Princeton University, Center for Environmental Studies, Report to the New Jersey Cabinet Energy Committee, June 1976).

10. The American Society of Planning officials (ASPO) has formulated a comprehensive resource pamphlet entitled Energy Efficient Planning: An Annotated Bibliography, available from them at 1313 E. 60 St., Chicago, Ill. 60637. FEA is also writing a handbook on energy conservation planning to be available by contacting William Raup, Office of Conservation and Environment, Federal Energy Administration, 12 th and Pennsylvania, N.W., Washington, DC 20461. 


\section{THE BROOKHAVEN NATIONAL LABORATORY REGIONAL ENERGY STUDIES PROGRAM}

The Brookhaven National Laboratory Regional Energy Studies Program is part of a national effort supported by the U.S. Energy Research and Development Administration (ERDA) to create an energy assessment capability which is sensitive to regional conditions, perceptions, and impacts. Within ERDA, this program is supported by the Division of Technology Overview and includes, in addition to a concern for health and environmental impacts of energy systems, analysis of the complex trade-offs between economics, environmental quality, technical considerations, national security, social impacts, and institutional questions. The Brookhaven Program focuses on the Northeast including the New England states, New York, Pennsylvania, New Jersey, Maryland, Delaware, and the District of Columbia. The content of the program is determined through an identification of the major energy planning issues of the region in consultation with state and regional agencies. A major component of the program in 1976 was the Northeast Energy Perspectives Study which examined the implications of alternative energy supply-demand possibilities for the region. In 1977 a major component is the northeast portion of the National Coal Utilization Assessment carried out in collaboration with several other laboratories in other regions of the United States. 